Portland State University

PDXScholar

Environmental Science and Management

Professional Master's Project Reports

Summer 2020

\title{
A Framework for Incorporating Benefits from Urban Forests into Planning for Livable Cities: a Case Study of Forest Park
}

Carole Hardy

Portland State University

Follow this and additional works at: https://pdxscholar.library.pdx.edu/mem_gradprojects

Part of the Environmental Sciences Commons, and the Other Forestry and Forest Sciences Commons Let us know how access to this document benefits you.

\section{Recommended Citation}

Hardy, Carole, "A Framework for Incorporating Benefits from Urban Forests into Planning for Livable Cities: a Case Study of Forest Park" (2020). Environmental Science and Management Professional Master's Project Reports. 59.

https://pdxscholar.library.pdx.edu/mem_gradprojects/59

https://doi.org/10.15760/mem.61

This Project is brought to you for free and open access. It has been accepted for inclusion in Environmental Science and Management Professional Master's Project Reports by an authorized administrator of PDXScholar. Please contact us if we can make this document more accessible: pdxscholar@pdx.edu. 


\title{
A framework for incorporating benefits from urban forests into planning for livable cities: A case study of Forest Park
}

\author{
Prepared for Renee Myers,
}

Executive Director, Forest Park Conservancy

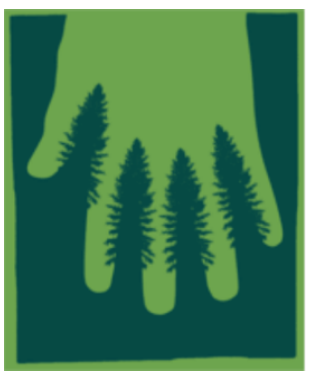

Prepared by Carole Hardy,

Master of Environmental Management Project

Portland State University

June 2020

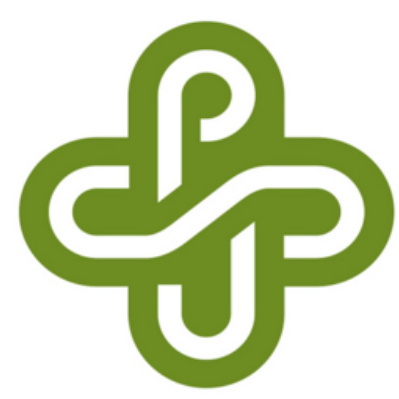




\section{A framework for incorporating benefits from urban forests into planning for livable cities: A case study of Forest Park}

\section{Acknowledgements}

My sincere thanks go my project partner, Renee Myers, who daily demonstrates the relentless effort it takes to advocate for and protect Forest Park. Her drive, leadership and innovation are an inspiration. Thanks to Kendra Petersen-Morgan for her guidance on this project. Kendra has been a key champion of Forest Park for over a decade. The reports and documents produced by Kendra and Renee guided my work. Thanks to Marshall Johnson who works tirelessly to keep the park healthy with his two hands, two feet, and deep knowledge of the ecology of the park. He gave me many hours of his scarce time to guide student projects on the impact of ivy on the park, and evaluation of the effectiveness of the restoration program. Many thanks to the Portland land managers and advocates who dedicated hours in workshops to develop a research agenda for Forest Park: Janelle St. Pierre, Becca Shively, Chris Prescott, Toby Query, Jeff Merrill, Alejandro Orizola and Cody Chambers. Thanks to the PSU faculty who participated in the West Side Natural area workshops and guided student ecological research in Forest Park: Dr. Jennifer Morse, Dr. Jeff Gerwing, Dr. Andres Holz, Dr. Marion Dresner, Dr. Cat de Rivera, Dr. Martin LaFrenz, Dr. Joe Maser and Dr. Leslie Bliss-Ketchum. Appreciation goes to PSU faculty who helped craft and refine socio-economic research for Forest Park: Dr. Randy Bluffstone, Dr. David Ervin, Dr. Max Nielsen-Pincus and Dr. Sahan Dissanayake. Many thanks to Dr. Priya Kansal and Dr. Yangdong Pan who guided the design of my blood pressure /stress study which I hope to complete when it is safe. I am ever so grateful to fellow grad student, Eric Butler, who was an excellent partner on Forest Park research, and contributed to this report in many ways. I thank Eric for his willingness to contribute his time and excellent analytic and writing skills to our projects. Thanks to Dr. Cat de Rivera who pointed me to the ESM graduate program and who taught me how to communicate science. Many thanks to Dr. Joseph Maser, my advisor, who has encouraged me and been steadfast in his support of my studies. Thank you to Dr. Sahan Dissanayake who taught me to speak the language of economics and encouraged me to get my Certificate of Sustainability. I thank Fletcher Beaudoin, Jihane Nami and Beth Lloyd at ISS who gave me the opportunity to bring PSU researchers and Portland area land managers together to set a future research agenda for Forest Park as an ISS Graduate Assistant. Thank you also to all of my family who supported me in so many ways through this journey. 


\section{List of terms}

- Ecosystem services: Ecosystem services are the direct and indirect contributions of ecosystems to human well-being. They support directly or indirectly our survival and quality of life (TEEB, 2010).

- Urban forest: For the purpose of this report, an urban forest is defined as a forested natural area that exists within urban boundaries. It does not refer to a network of urban street trees.

- Novel ecosystem: A novel ecosystem is one that does not have a current or historical reference due to past and current disturbance to ecological function.

- Sustainable development - Adopted in 2015 by all members of the United Nations, the 2030 Agenda for Sustainable Development establishes 17 sustainable development goals that serve as guides for developed and developing countries with the aim to end poverty and other global inequities.

- Sustainability: Meeting the needs of the present without compromising the ability of the future generation to meet theirs.

- Sustainable Development: Development that balances economic, environmental and social sustainability.

- Social Equity: Social equality is a state of affairs in which all people within a specific society or isolated group have the same status in certain respects, including civil rights, freedom of speech, property rights, and equal access to social goods and services

- Resilient cities: Resilient cities have the ability to absorb, recover and prepare for future economic, environmental, social and institutional shocks. Resilient cities promote sustainable development, well-being and inclusive growth. 


\section{Table of Contents}

List of Tables and Figures 6

$\begin{array}{ll}\text { Executive Summary } & 7\end{array}$

The Project: Hypothesis and Research Questions 10

Urban Forests: The Benefits and the Challenges 11

$\begin{array}{ll}\text { An Urban Forest Case Study of Forest Park } & 15\end{array}$

First People of the Land 16

$\begin{array}{ll}\text { Protected from Development } & 17\end{array}$

$\begin{array}{ll}\text { Methods } & 18\end{array}$

$\begin{array}{lr}\text { General } & 18\end{array}$

$\begin{array}{lr}\text { Methods by Research Question } & 19\end{array}$

Q1 19

Q2 21

Q3 22

Q4 23

Q5 24

Findings

Q1

Impact of Ivy Invasion $\quad 25$

Observations of Ecological Conditions 26

Analysis of Data Collect at Balch Creek Restoration Plots 28

Limitation of Research $\quad 30$

Q2 $\quad 30$

Q3 231

Historic \& Chronic Underfunding of Portland's City Parks 31

Property Tax Limitations

Corporate Tax Limitations 33

Current Funding Challenges $\quad 35$

Q4 36

Q5 40

Summary of Interviews with Portland Businesses 41

Urban Forest Services Framework 43

Identifying Goals and Prioritizing Actions 46

Urban Forests Benefits Matrix for Forest Park 49 
Urban Forest Causal Chains for Forest Park

Protect Water Quality 53

Protect Air Quality $\quad 56$

$\begin{array}{ll}\text { Protect Wildlife } & 59\end{array}$

Provide Access to Nature $\quad 62$

Benefits to Beneficiary Map for Forest Park 66

Beneficiary to Resource Map for Forest Park 68

Funding Recommendations $\quad 69$

Research Recommendations

$\begin{array}{ll}\text { General Forest Health } & 72\end{array}$

Ivy Ecology and Management $\quad 73$

$\begin{array}{ll}\text { Need for Data } & 73\end{array}$

$\begin{array}{ll}\text { Plot Scale } & 73\end{array}$

$\begin{array}{ll}\text { Landscape Scale } & 74\end{array}$

$\begin{array}{ll}\text { Historical } & 74\end{array}$

$\begin{array}{ll}\text { Current Considerations } & 75\end{array}$

$\begin{array}{ll}\text { Impact of Coronavirus } & 75\end{array}$

Metro and City of Portland Bond Measures $\quad 76$

$\begin{array}{ll}\text { Summary } & 77\end{array}$

$\begin{array}{ll}\text { References } & 78\end{array}$

Appendices

$\begin{array}{ll}\text { A. Business Questionnaire } & 86\end{array}$

$\begin{array}{ll}\text { B. Business Survey } & 88\end{array}$

C. Employee Survey $\quad 99$

$\begin{array}{lr}\text { D OWEB Technical Assistance Grant Proposal - Link } & 107\end{array}$

E. Hardy et al. (2018) Impact of Ivy on Forest Park; Management considerations - Link 107

F. Hardy et al. (2019) Current and Future Ecological Conditions of Forest Park - Link 107

G. Blood Pressure, Stress Study Design 108 


\section{List of Tables and Figures}

$\begin{array}{ll}\text { Figure } 1 \text { Urban Forest Services Framework } & 9\end{array}$

Figure 2 Recommended Funding for Portland Parks District and FPC 10

Figure 3 Organizational and Ecological Challenges facing US Urban Forest Managers 15

Figure 4 Map of Forest Park 16

Figure 5 Map of Balch Creek Treatment Areas $\quad 29$

Figure 6 Impact of Measures 5 and 50

Figure 7 Nike's Diminishing Tax Liability 34

Figure 8 Corporate Share of Oregon Income Taxes 35

Figure 9 Oregon's Business Taxes Tied for Lowest in US 35

Figure 10 PP\&R Distribution of Expenses 2019

Figure 11 Map of Portland Metro Businesses Targeted for Partnerships 42

Figure 12 Urban Forest Services Framework 45

Figure 13 Dimensions of Sustainable Development 46

Figure 14 Urban Forest Benefits Matrix Goal $1 \& 2$

Figure 15 Urban Forest Benefits Matrix Goal 3 \& 4

Figure 16 Changes in ES and Associated Societal Values 51

Figure 17 Goal 1/Action 1 Causal Chain - Protect Water Quality 54

Figure 18 Goal 1/Action 2 Causal Chain - Protect Water Quality 55

Figure 19 Goal 1/Action 3 Causal Chain - Protect Water Quality 56

Figure 20 Goal 2/Action 1 Causal Chain - Protect Air Quality 58

Figure 21 Goal 2/Action 2 Causal Chain - Protect Air Quality 59

Figure 22 Goal 3/Action 1 Causal Chain - Protect Wildlife 61

Figure 23 Goal 3/Action 2 Causal Chain - Protect Wildlife 62

Figure 24 Forest Park Recreation Calculator

Figure 25 Goal 4/Action 1 Causal Chain - Provide Access to Nature 64

Figure 26 Goal 4/Action 2 Causal Chain - Provide Access to Nature 65

Figure 27 USFS Elements

Figure 28 Forest Park Benefits to Beneficiary Map 67

Figure 29 Forest Park Beneficiary to Resource Map 69

Figure 30 Recommended Funding for Portland Parks District and FPC 72

Table 1 Objectives to Protect the Environment and Watershed Health 47

Table 2 Climate Change Preparation Objectives for Portland 48

Table 3 Goals of Conservation Activities, GFPCl 49 


\section{Executive Summary}

Urban forests provide an escape from the noise and chaos of cities. Other services can be overlooked and under-valued. Urban forests cool and filter the air, sequester carbon, filter water removing toxins and sediments from urban runoff, provide habitat for wildlife and improve human health and well-being. Commonly urban forests in the United States (US) lack funds for restoration and research because there is lack of understanding of the need to actively manage what are perceived as wild lands. Generally urban forests are highly disturbed and novel ecosystems that require ongoing active management to remove invasive species, replant native species and restore streams. Pressures from urbanization threaten the health of these ecosystems with air pollution from transportation and industry, increasing demand for recreation from rising urban populations and climate change.

Portland's Forest Park is touted as the crown jewel of the Portland parks system, yet it suffers from the same lack of dedicated funding as many other urban forests and there are signs that the forest's health is at risk. Surprisingly there are few long-term studies of the ecological trends in Forest Park and no formal research agenda. A comprehensive review of the studies that do exists reveal a highly disturbed ecosystem, one that was logged extensively in the $19^{\text {th }}$ and $20^{\text {th }}$ centuries with downed wood removed. Ecological studies conducted within Forest Park over the past decades by academic researchers from Portland State University and Linfield College, reveal that heavy tree mortality and lack of recruitment of late seral species indicating a lack of resilience. Continued disturbance from recreation on the 80+ miles of trails, invasive plants and climate change continue to put pressures on this ecosystem with the risk of a regime shift in some areas of the park.

Forest Park is a municipal natural area managed by Portland's Parks and Recreation Department in close partnership with the Forest Park Conservancy (FPC), a citizen-led non-profit organization that maintains trails and promotes park stewardship. FPC is the community partner for this project. In 2013, FPC published the Greater Forest Park Conservation Initiative (GFPCI) developed to guide restoration and protection of the Forest Park ecosystem (Meyers et al. 2013). Recognizing that the management of Forest Park and the surrounding lands for conservation would take the commitment of multiple organizations working together, the GFPCI was jointly published by the Forest Park Alliance, a consortium of government, non-government and private organizations. Threats to the ecosystem along with conservation goals, objectives and activities are documented in this plan. The key barrier to 
implementation of the plan is lack of sustainable funding. FPC seeks to identify opportunities to secure such funding (Myers, personal conversation, 2017).

As public land protected from logging and without fees, there is no revenue from Forest Park. On the books, Forest Park has no recorded value to offset the costs of managing the forest for resilience, providing access to the park, building and maintaining infrastructure, and conducting ecological research to inform management actions. Assessing the value of ecosystem services is becoming a more common way to assign value to non-market goods such as those provided by urban forests. Without markets for these services, stakeholders must have tools to quantify the social-ecological values associated with the management of urban forests to be resilient to the ongoing disturbances from urbanization and climate change.

In response to this challenge, I developed the Urban Forest Services Framework (UFSF) which establishes a process and tools for identifying and analyzing linkages and dependencies between natural and human systems. It provides a tool for urban planners and natural resource practitioners to integrate conservation of urban forests into urban planning via inclusive stakeholder engagement in a way that offers an alternative to strict monetary valuation of the services.

The UFSF provides a way for planners to identify values associated with management actions in terms of ecological and societal benefits. The UFSF framework guides a systematic approach to communityengaged land-use planning that prioritizes localized societal needs. A simplified overview of the UFSF is shown in Figure 1. Goals and Actions that stabilize or increase the ecosystem services provided by a specific urban forest are first identified then captured in the Urban Forest Benefits Matrix. Next Urban Forest Causal Chains are developed to identify the desirable benefits and societal values resulting from the actions. The matrix is completed by cataloging the co-benefits of each action. Benefits are mapped to beneficiaries then mapped to potential resource and funding sources. This represents a deliberative valuation approach combining non-market valuation of ecosystem services with discussion among stakeholders. 


\section{Urban Forest Services Framework}

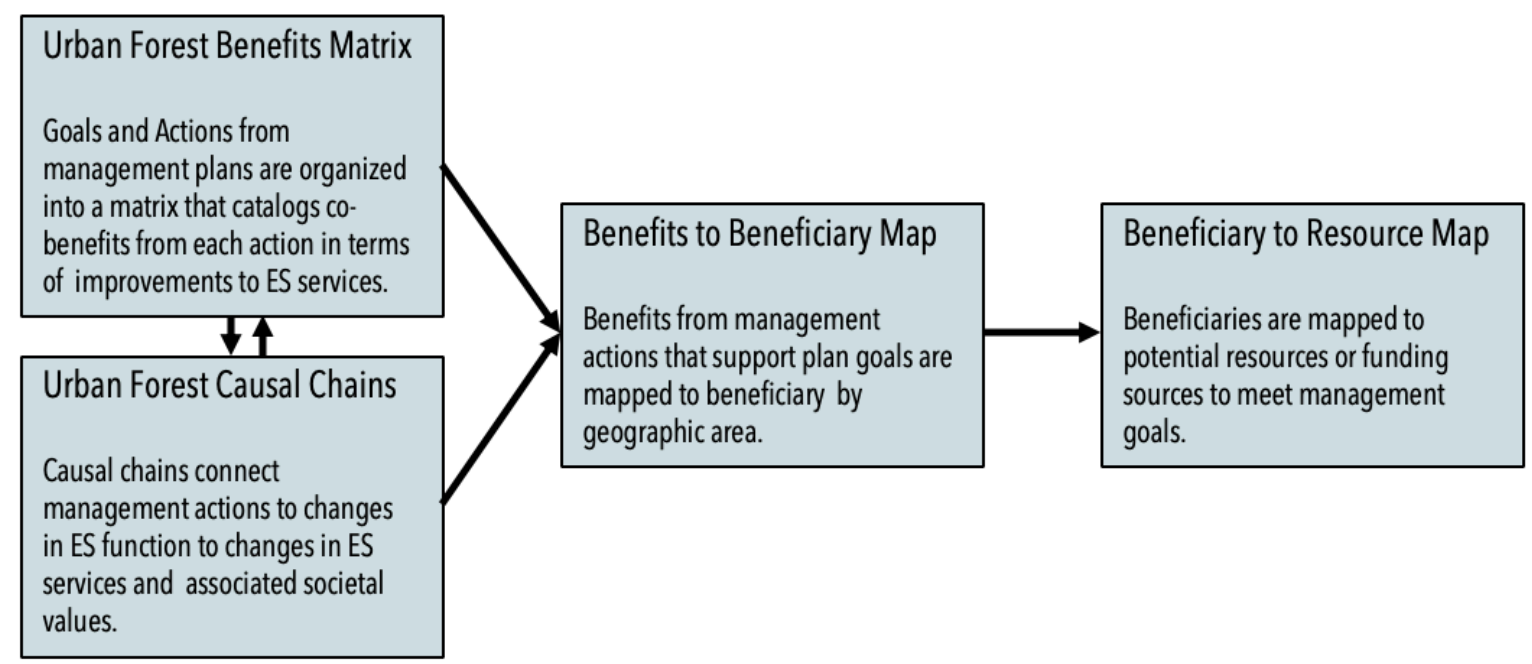

Figure 1. A simplified overview of the UFSF is shown here. Goals and Actions would first be identified and captured in the Urban Forest Benefits Matrix, then Urban Forest Causal Chains are developed to identify benefits and societal values resulting from the actions. The matrix is completed by cataloging the co-benefits of each action in the Benefits to Beneficiary Map. Benefits are then mapped to potential resource/funding sources in the Beneficiary to Resource Map.

Applying the USFS to the case study of Forest Park and the Portland Parks system, it is recommended that a separate Parks District with dedicated funding be established, with funds flowing from the beneficiaries of the ecosystem services provided by park lands. Funding for the Parks District is aligned with the beneficiaries of services as illustrated in Figure 2. Sources and mechanisms include: a property tax increase on properties that are adjacent to natural areas, a set percentage transferred from Oregon Metro to the Parks District and FPC to fund projects that can be supported under the Parks and Nature Bond, a Willamette River water recreation tax, a set percentage of current property tax revenue transferred from the City of Portland's general fund budget, an additional transient room tax, a tax on prepared food and beverages, a progressive corporate tax on businesses, funding from State Parks (a portion of Oregon Lottery profits) to fund restoration projects that sequester carbon, and a progressive income tax for Metro residents that make more than $\$ 125,000$, or some combination of the above. 


\section{Recommended Funding and Operations Model for Portland Parks District and FPC}

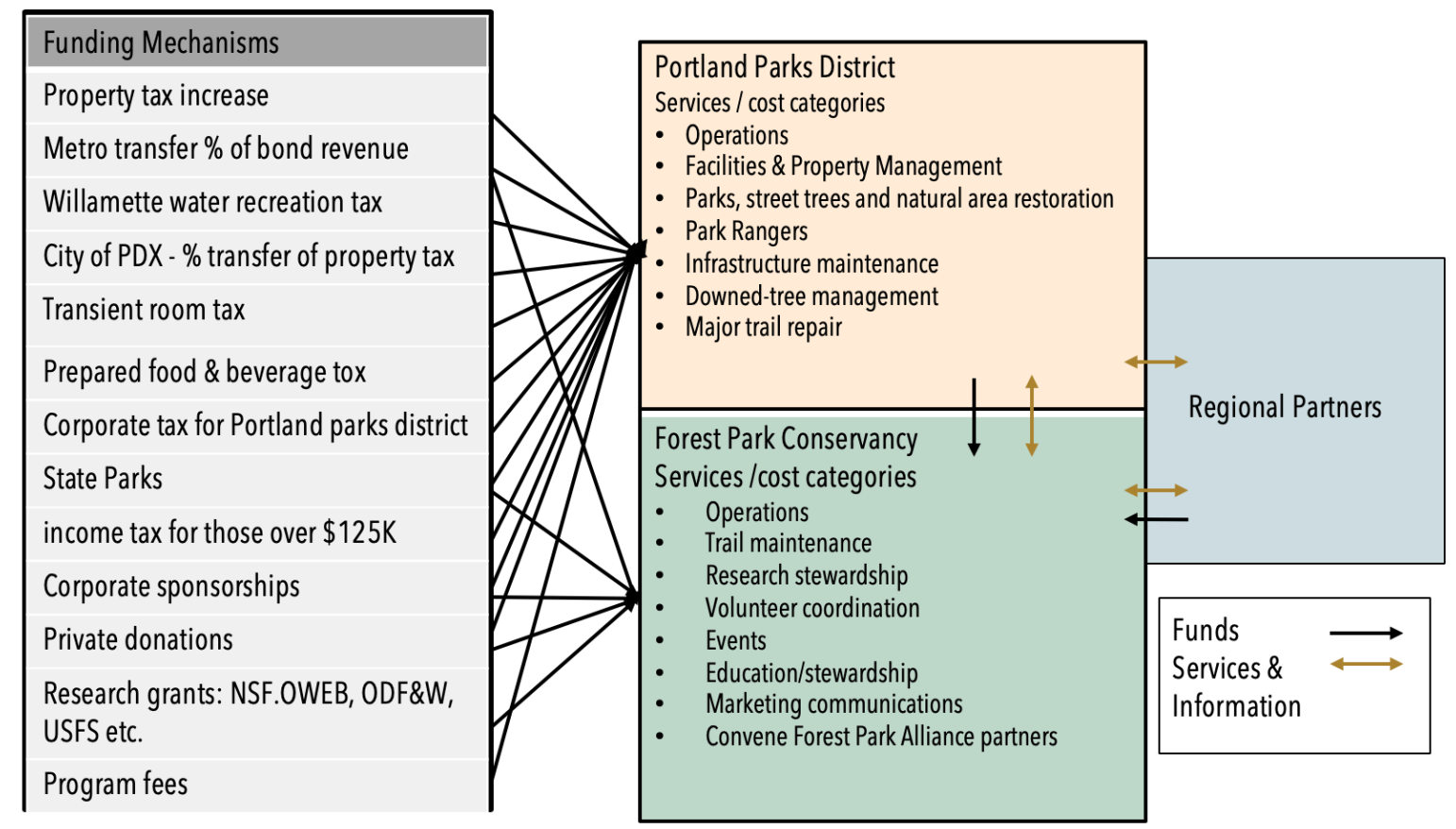

Figure 2. This funding and operations model illustrations the funding sources and funds that would be allocated to the Portland Parks District and to FPC. High level services and costs categories are listed within the Parks District and FPC boxes. Black arrows indicate a flow of funds. Brown double sided arrows represent a flow of information and services such as results of research studies, infrastructure maintenance by BES, educational program content from the Audubon Society.

In this uncertain economic climate caused by the coronavirus, it may be challenging to find city champions to launch the initiative to create a Parks District, but it is time to begin to rally supporter of this concept. According to a recent survey of Portlanders conducted by Portland Parks and Recreation, 93\% agree that it's important to maintain existing parks, natural areas and facilities.

I recommend that priority be given to formalizing a Forest Park ecological research agenda to inform management actions. In parallel, I recommend that FPC attempt to secure sponsorships and donations to fund a campaign that informs the public of the risks to health of Forest Park without dedicated and sustainable funding for informed management.

\section{The Project}

My aim is to document the ecological and funding challenges faced by urban forest land managers and conservation advocates, and to identify viable and sustainable funding mechanisms for effective 
management. As one of the largest urban forests inside city limits in the United States (US), Portland's Forest Park is the case study for this project. A Portland native living in the west hills of Portland with a formal education in forest management, I have witnessed a decline in Forest Park health over the past decades. The observable disturbance from invasive plants motivated my selection of Forest Park as my study area. Prior to beginning my graduate studies at Portland State University (PSU), I met the Executive Director of the Forest Park Conservancy (FPC), Renee Myers, and gained a preliminary understanding of the barriers to restoring and enhancing the health of the forest. Myers highlighted the need for financial resources and the challenges associated with securing those resources (Myers, personal conversation, 2017). Following initial discussions with Myers, I formulated a hypothesis that framed this Master of Environmental Management (MEM) project.

Hypothesis: Forest Park is economically undervalued, and the resources required to manage this novel ecosystem for resilience, while meeting the demands for recreation, are significantly underestimated resulting in chronic underfunding of park management and a degrading ecosystem.

Through additional interviews with researchers who study in Forest Park and land managers who work in Forest Park I developed five research questions which are answered in this report.

1. What is the trend of ecosystem health in Forest Park?

2. What are the key challenges to managing Forest Park to achieve ecologic goals while meeting the demand for access to the park for recreation?

3. Are adequate resources available to meet the documented management needs? If not, why not?

4. What methods or frameworks are available to identify and quantify the benefits from publicly owned urban forests?

5. What methods of sustainable funding for urban forests exist in, and are recommended for managing Forest Park and Portland Parks in general?

\section{Urban Forests - the Benefits and the Challenges}

Urbanization poses threats to what seem like disparate areas of human health, ecological systems and social systems. Urban development does not typically consider the environmental services provided by urban forests and other types of urban ecosystems. Land-use decisions often fail to reconnect ecosystems or further fragment them, resulting in continued loss of biodiversity and declining human 
health, particularly among vulnerable populations. With over $68 \%$ of the world's population expected to live in urban areas by 2050 (World Health Organization, 2012), urban development needs to be guided in a way that promotes biodiversity and human health through the protection of social and ecological systems (Sushinsky et al. 2013). Conservation of urban forests is a key strategy for resilient cities as the ecosystems provide a myriad of services to urban dwellers (Turner-Skoff \& Cavender 2019).

Most urban area are a mosaic of land parcels with multiple owner who have different objectives and usually competing goals. A publicly owned forest conserved with revenues from property tax might be next to land owned by profit-driven manufacturing company with a high percentage of impervious buildings, parking lots and roads that create an urban heat island and contributes to urban stormwater runoff; both properties bordered by transportation networks that crisscross the landscape lowering the permeability for wildlife movement. Urban planners must balance the need of transportation, development and economic prosperity, but frequently lack the skills, tools and political support to integrate these while protecting ecosystem functions. As such, conservation initiatives that protect and restore urban forests and other functioning ecosystems are often deprioritized in urban areas where space is at a premium and economic development and jobs are key priorities (Pew Charitable Trusts, 2012). Often purchasing land for conservation and investment in management of publicly owned urban forests and park lands falls below other municipal priorities such as the need for housing and public safety (Buscher et al. 2012; Harvey 2004, TEEB 2010).

Failing to integrate ecosystem connectivity and protection of urban forests into urban planning impacts people's lives and biodiversity. As urban areas expand, impervious surfaces increase which results in an urban heat island effect which causes increased rates of heat related illness and stroke, decreased productivity, and increased mortality (Daanen et al. 2013, Fahy et al. 2019). The urban heat island effect frequently has a disproportionately negative impact on underserved communities, which often lack nearby green spaces to reduce the heat and offer escape from it, and dwellers may lack the resources to pay for cooling systems (Fahy et al. 2019, Rao et al. 2014, Shandas, et al. 2019, Voelkel et al. 2016). Untreated road runoff negatively impacts water quality and endangers human, fish and invertebrate health and specifically threatens the survival of migrating salmonids (McIntyre et al, 2015, Sommers et al. 2015, Walsh et al. 2005). Runoff from roads typically contains elevated metals; polycyclic aromatic hydrocarbons (PAHs) from combustion of coal, oil, petrol and wood; and organic matter (Mclntyre et al. 2015). Fragmentation of terrestrial habitats in built environments can lead to local extinctions of species 
such as pollinators, migrating birds and amphibians (Dournier \& Cheptou 2011, Huste et al. 2007, Vos et al. 2002) and may decrease options for climate-caused range shifts, especially along developed river valleys (Keeley et al. 2018).

Urban planning that takes into consideration the benefits from urban forests not only protects biodiversity of the region but can address a wide range of human health and societal concerns (Elmqvist et al. 2015, Dournier \& Huste, 2011, Van der Bosch et al. 2018). Human access and even proximity to green spaces can reduce depression and stress (Dratva et al. 2010, Gunnarson \& Ohstrom 2007, Li \& Sullivan 2016, Li et al. 2016, Shanahan et al. 2015). Physical health of city dwellers improves with increased tree canopy, which connects ecosystems and acts as an air filter reducing rates of respiratory illness (Escobedo et al. 2009, 2011, Nowak et al. 2018, Rao et al. 2014). Tree canopy provides shade, curbing rates of heat stroke and mortality (Hardin et al. 2007, Kravchenko et al. 2013) and reduces cooling costs when planted near buildings reducing greenhouse gas emissions (Donovan \& Butry 2018). Risk of pulmonary disease can decrease with time spent recreating in nature (Rosenberger \& Dunn 2018). Moreover, green spaces integrated throughout the built environment help to support environmental justice by providing equitable access to multiple natural benefits including reduced depression, childhood obesity, childhood asthma, and rates of other chronic respiratory disease across neighborhoods (Baro et al. 2019, Turner-Skoff \& Cavender, 2019, Voekel et al. 2018).

Assigning appropriate values to actions and policies that maintain or restore functioning ecosystems could be an effective way for city planners to make ecological and human health issues central to urban planning processes. Valuation of ecosystem services (ES), the benefits people derive from nature, has been increasingly used in the past three decades to inform decision and policy making related to land-use decisions that support sustainability and conservation of nature (Costanza et al. 1997, 2014; MEA 2005; Olander et al. 2018; TEEB 2010). ES can be linked to human well-being as is demonstrated in the Millennium Ecosystem Assessment (MEA) report (MEA 2005) and can be used to examine how changes in ecological systems affect people and societies. Valuation of ES is often not included in urban land-use planning assessments because values are not readily available or not credible when services are not traded on markets (Ervin et al. 2014).

Assigning monetary value to ES is becoming more common, but this method is not without its critics. Critics assert that by assigning market values to nature, nature is incorporated into profit-driven markets, 
failing to capture the full worth of scarce resources (Buscher 2012; Harvey 2004, 2005). Others warn that assigning monetary values undermines nature's intrinsic value and can create inequities (Block 2001, Polanyi 1944). However, if conservation does not speak the language of economics, there is risk that nature will continue to lose out to development in land-use decisions especially in cramped urban environments, with little chance of competing for funds from strapped municipal budgets.

One method to integrate benefits of ES that does not rely on the assignment of monetary values to nature's benefits is by using benefit relevant indicators (BRIs), which link management decisions through ecological actions to impacts on human well-being (Olander et al. 2018). BRIs identify which benefits of nature are important to different groups of people at different locations linking them through causal chains. BRIs can be used as values themselves (e.g., reduced exposure to nitrous oxide (NOx), an atmospheric pollutant) or as a method to assign monetary value when possible or relevant. Rao et al. estimated that the $\mathrm{NO}_{2}$ reduction associated with trees in Portland could result in significantly fewer incidences of respiratory problems, providing a \$7 million USD benefit annually (Rao et al. 2014). BRIs provide intuitive inputs into an ES analysis for urban planning because they have a direct link to social value. The use of BRIs in land-use planning makes it clear what outcomes are being valued by stakeholders.

Natural areas accounted for 84\% of urban parkland according to one study conducted in 2012 (Pergitzer et al. 2012). Urban forests deliver high value services in the form of carbon sequestration, air and water filtration, shade, provision of wildlife habitats among others (Turner-Skoff \& Cavender 2018), yet US cities face significant and common challenges to the protection of the health of these novel and highly disturbed ecosystems. Pregitzer et al. in a 2012 study that surveyed land managers of publicly owned forested natural areas in the US found the top challenges to be limited funding, limited data and invasive species (Pregitzer et al, 2012). Portland Parks and Recreation (PP\&R) was one of the organizations surveyed with some of the survey results from this study show in Figure 3. 


\section{Organizational Challenges}

The relative importance rank of organizational challenges reported by participating organizations.

= Very Important In Important Moderately Important $\quad$ Somewhat Important Not Important

\begin{tabular}{|c|c|c|c|c|c|c|}
\hline Limited Funding or Staff & \multicolumn{3}{|c|}{$82 \%$} & & $12 \%$ & $6 \%$ \\
\hline Limited Data & $35 \%$ & \multicolumn{2}{|c|}{$42 \%$} & \multicolumn{2}{|r|}{$18 \%$} & $5 \%$ \\
\hline $\begin{array}{l}\text { Low Awareness of Forested } \\
\text { Natural Areas }\end{array}$ & $30 \%$ & \multicolumn{2}{|c|}{$40 \%$} & $16 \%$ & & $4 \%$ \\
\hline Limited Policy & $25 \%$ & $35 \%$ & $19 \%$ & & $12 \%$ & $9 \%$ \\
\hline $\begin{array}{l}\text { Uncertainty in Management } \\
\text { Approach }\end{array}$ & $21 \%$ & $35 \%$ & $21 \%$ & & $13 \%$ & $10 \%$ \\
\hline
\end{tabular}

\section{Ecological Challenges}

The relative importance of ecological challenges reported by participating organizations.

Wery Important $\quad$ Important $\quad$ Moderately Important $\quad$ Somewhat Important Not Important

\begin{tabular}{|c|c|c|c|c|c|}
\hline Invasive Species & \multicolumn{3}{|c|}{$79 \%$} & $15 \%$ & $4 \%$ \\
\hline $\begin{array}{l}\text { Disrupted Natural Processes Due } \\
\text { to the Urban Context }\end{array}$ & $42 \%$ & $25 \%$ & $17 \%$ & $11 \%$ & $5 \%$ \\
\hline Negative Human Use & $39 \%$ & $26 \%$ & $20 \%$ & $8 \%$ & $7 \%$ \\
\hline Climate Change Stressors & $35 \%$ & $33 \%$ & $15 \%$ & $11 \%$ & $5 \%$ \\
\hline Wildlife Impacts (e.g., deer browse) & $34 \%$ & $29 \%$ & $17 \%$ & $13 \%$ & $7 \%$ \\
\hline
\end{tabular}

Figure 3. Results from a survey of 24 US land managers reveal that the top organization challenges for managing forested natural areas for resilience are limited funding and staff, limited data, low awareness and other factors. Top ecological challenges rank from very important, invasive species, to least important wildlife impacts. Source: , Pregitzer et al, 2012, Untapped Common Ground: The Care of Forested Natural Areas in American Cities

\section{An Urban Forest Case Study: The Land Now Known as Forest Park}

The land designated as Forest Park is a pubic, municipal natural area that runs along the east slopes of the Tualatin Mountains in Multnomah County in the City of Portland overlooking the Willamette River (Figure 4). Held in trust by the City of Portland, this land features 80 miles of maintained trails (The Trust for Public Lands, 2008). A 5,128 acre second-growth forest visited by an estimated 550,000 people annually (Van Deren et al, 2018), Forest Park is one of the largest urban parks within a city in the US. Heralded as the 'crown jewel' of Portland's park system (Fish, 2010), Forest Park is frequently featured in marketing communication campaigns encouraging businesses to locate and visitors to travel to Portland to enjoy the beauty of a forest within the city limits among Portland's other amenities. For the residents of Portland, Forest Park provides an escape from the noise and chaos of the urban environment and opportunity to run, walk, bike and observe the wildlife. 


\section{Balch Creek Restoration Area}

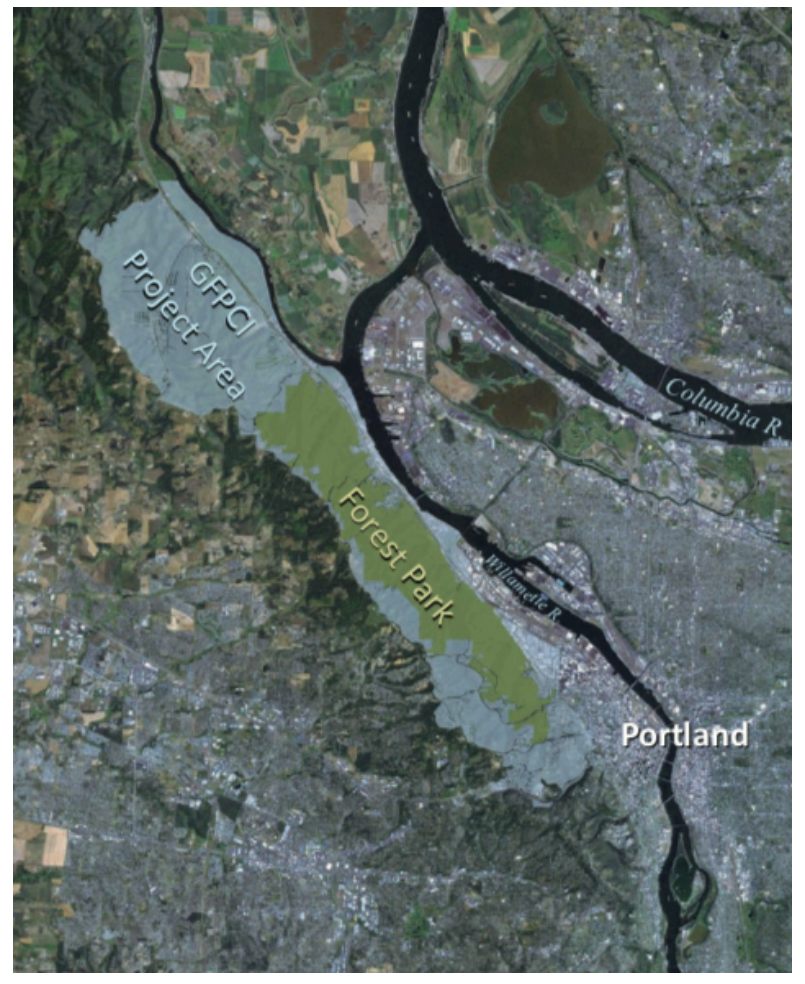

Figure 4. This map shows the location of Forest Park and the surrounding acreage called the Forest Park Conservation Area. They are located in the Tualatin Mountains overlooking the Willamette River in the city of Portland, Oregon.

\section{First People of the Land}

The confluence of the Columbia and Willamette Rivers and the surrounding areas forms the Portland basin. Humans first inhabited the region about 11,000 years ago. Small, nomadic groups of people came to this area to gather food. They fished for salmon, sturgeon, and smelt in the rivers, hunted game and gathered nuts, berries, roots and bulbs. The earliest inhabitants were Chinookan-speaking people include the including the Clackamas, Kathlamet, Multnomah, and Tualatin (Oregon Historical Society, n.d.-a). Lewis and Clark described twenty-five villages on the Willamette River about 15 miles northwest of the present-day Portland. British and American fur companies came into the basin in the early 1800 s and traded with the Chinookan villagers. The trappers, missionaries and settlers introduced diseases including smallpox and measles creating epidemics resulting in losses of between 50 and 90 percent of first people populations. By the mid-1800's, the surviving Native people were relocated by state and federal authorities to reservation lands (Oregon Historical Society, n.d.-a). 


\section{Protected from Development}

Early European-settlers extensively logged Forest Park and the surround areas in the 19th and 20th centuries. Stand-replacing fires burned in 1889, 1940, and 1951 leaving one small parcel of old growth the forest within the park area (Copp, 2014). As early as the 1860's, civic leaders in Portland advocated for the creation of a natural preserve in the forests above Portland which led to the creation of a municipal park commission. In 1903 the Commission hired John and Frederick Olmsted Jr. (sons of the Frederick Olmsted who designed New York's Central Park and other iconic green spaces) to develop a plan for the Lewis and Clark Exposition to be held in Portland in 1905 celebrating the $100^{\text {th }}$ year anniversary of the Lewis and Clark expedition. While on their visit to Portland, the Olmsted brothers created a plan for Portland's parks system which envisioned a network of green spaces across Portland connecting the city, west to east and north to south with Forest Park an anchor to the Oregon's Coast Range (Oregon Historical Society n.d.-a).

While the vision was embraced by the people of Portland, it took until 1948 to officially set aside the lands of Forest Park under the management of what was then called the Portland Parks Bureau (PP\&R 2010). Acquiring land through donations, transfers from Multnomah County and delinquent tax foreclosures, the city acted on a proposal by the City Club of Portland (originally called the Committee of Fifty) and combined parcels totaling about 4,000 acres to create the forest reserve (PP\&R 2010, Trust for Public Land, 2008). The forest reserve narrowly avoided large-scale residential development, largely due to its geologic unsuitability. The civic-minded individuals that fought to originally protect the park formed an organization that continued to advocate and work for the preservation and protection of Forest Park over the decades. Originally called the Friends of Forest Park, the organization is now known as the Forest Park Conservancy (PP\&R 2010) a community-led independent non-government agency (NGO). Today, Forest Park is managed by Portland Parks and Recreation (PP\&R) in partnership with FPC and other government and NGO organizations (Myers et al. 2013).

Like most urban forests in the US, today the Forest Park ecosystem continues to be disturbed by recreational activity and pressures from urbanization including air pollution, invasive species and impacts from climate change. Some areas of Forest Park, particularly in the southern end of the park, have been altered to the point of being novel ecosystems, relatively stable states with unprecedented biotic communities and ecological processes according to several studies conducted within Forest Park (Dresner et al, 2017, Hardy, Butler \& Hadzinski, unpublished paper 2018). 
Designated as a public natural area by PP\&R, Forest Park brings in no revenue to offset the costs incurred by PP\&R and FPC to protect the ecosystem functions of the park, to build and maintain trails, to coordinate volunteers and education programs and to conduct science-based research needed to inform management decisions. With ongoing disturbances from rising populations and climate change, the challenges of managing this 5,200 acres urban forest for resilience are complex. The barriers facing land managers significant. In depth research reveals the complexities and dynamics associated with the management of Forest Park.

\section{Methods of Gathering Data}

Goals and objectives for managing Forest Park for resilience are identified in multiple documents including the Greater Forest Park Initiative (GFPCl) (Myers et al. 2013) and Forest Park Ecological Prescriptions (PP\&R 2011). Lack of sustainable funding to conduct science-based research that will inform specific adaptive management actions, for stewardship programs and trail maintenance leave FPC and $P P \& R$ in a position to constantly seek grant funding and donations, and to battle for a share of the City of Portland's municipal budget. FPC seeks a method of effectively communicating the need for funding and for securing sources.

Myers recommended I review the $\mathrm{GFPCl}$ as an introduction to the ecological conditions of Forest Park and the partners of the Forest Park Alliance working toward conservation of the area. Myers also provided a list of stakeholders involved in Forest Park land management, and a list of FPC / PP\&R research initiatives in progress with PSU faculty. Prior to beginning my studies in the fall of 2017, I developed a method to gather information to inform my project and answer my research questions which was refined throughout the course of my research and is described here.

\section{General Methods}

Six general methods were employed to gather information.

- Comprehensive literature reviews on many topics informed answers to research questions.

- Stakeholders interviews with land managers and researchers helped refine my research questions, prioritizes areas of study through course work and independent research. 
- Stakeholder interviews with representatives from business informed an approach for increasing sponsorship support of FPC.

- Course work helped provide answers to my research questions via lectures, readings and individual and group project work.

- Stakeholder workshops brought together PSU researchers and Portland land managers and conservation advocates. Workshops funded by PSU's Institute for Sustainable Solutions (ISS) which were facilitated by me as an ISS Graduate Assistant (GA), helped prioritize research questions and research projects for Forest Park.

- Data analysis of restoration data collected in Forest Park was conducted which resulted in recommendations for future data collection methods.

\section{Methods by Research Question}

Described here are the specific methods used to answer each of my five research questions. Findings are detailed the following section.

\section{Q1. What are the ecological trends in Forest Park?}

\section{Literature Review:}

Google Scholar and PDX Scholar searches revealed studies that had been conducted on plots within Forest Park. Findings from these studies informed a report entitled Impacts of Ivy in Forest Park:

Management Considerations prepared for Marshall Johnson, Natural Areas Ecologist at PP\&R and Dr. Cat de Rivera (Hardy, Butler \& Hadzinski, unpublished paper 2018).

\section{Stakeholder interviews:}

Current plans and reports that document ecological conditions and desired conditions for Forest Park used to guide management practices were identified through interviews with Kendra Petersen-Morgan, West Side Natural Areas Supervisor, PP\&R; Marshall Johnson, Natural Area Ecologist, PP\&R; and Renee Myers, Executive Director, FPC. Plans and reports informed the management priorities of the Benefitscentric Ecosystem Services Framework presented in a later section of this report. 


\section{Course work:}

Multiple ESM courses provided case studies and methods of evaluating ecological health of novel urban ecosystems namely Ecosystem Restoration (ESM 516), Forest Ecology (ESM 544), Ecosystem Sustainability (ESM 588), Ecology \& Management of Bio-invasions (ESM 585), and Ecotoxicology (ESM 520).

\section{Stakeholder workshops:}

Initial stakeholder workshops with PSU researchers and Portland area land managers were convened in May through August 2018 to identify and prioritize the need for research including both socio-economic and ecological research needs. Additional workshops were conducted from September 2018 - September 2019 to discuss the findings from research projects conducted over the course of the years, and to agree on next steps. The following stakeholders attended some or all of the workshops.

- PSU Researchers Studying in Forest Park: Dr. Sahan Dissanayake, Assistant Professor Economics; Dr. Randy Bluffstone, Professor of Economics; Dr. David Ervin, Professor Emeritus Economics and ESM; Dr. Andres Holz, Assistant Professor Geography; Dr. Martin LaFrenz. Associate Professor Geography; Dr. Joseph Maser, Assistant Professor ESM; Dr. Cat de Rivera, Professor ESM; Dr. Jeffrey Gerwing; Associate Professor ESM, Dr. Marion Dresner; Professor Emeritus ESM; Dr. Jennifer Morse; Associate Professor ESM; Max Nielsen-Pincus; Assistant Professor ESM, Eric Butler, graduate student MEM; Leslie Bliss-Ketchum, the PhD candidate ESM, and Randy Morris, PSU's Institute for Metropolitan Studies.

- Portland Area Land-managers and NGO Representatives Working in Forest Park: Renee Myers, Executive Director FPC; Alejandro Orizola, Project Manager FPC; Cody Chambers, Ecologist FPC; Kendra Petersen-Morgan, West Side Natural Area Manager, PP\&R; Marshall Johnson, Ecologist PP\&R; Janelle St. Pierre, Ecologist PP\&R; Jeff Merrill, Ecologist Metro; Chris Prescott, Watershed Ecologist, Bureau of Environmental Services (BES); and Toby Query, Ecologist, BES.

- ISS Staff: Fletcher Beaudoin, then Assistant-Director ISS; Jihane Nami, Project Manager; Beth Lloyd, Project Manager; and Carole Hardy, ISS Intern/Graduate Assistant.

Workshops resulted in a prioritized list of research priorities, individuals interested in continuing discussions, and next steps. 


\section{Data analysis:}

In January 2019, ISS funded a Forest Park Restoration Effectiveness data analysis project for PP\&R and FPC. Dr. Jennifer Morse, Dr. Jeff Gerwing and Dr. Andres Holz and Marshall Johnson of PP\&R consulted on the design of project. As GA I directed and contributed to the work and led the writing of the report entitled Assessment of Current and Future Conditions of Forest Park: Management Considerations. Current restoration within Forest Park is being conducted by PP\&R and is focused in the 580-acre portion of Forest Park in the Balch Creek watershed. Portions of this land are in varying states of restoration including invasive weed removal and replanting with native species. Scope of the study is to focus on the effectiveness of restoration actions by analyzing monitoring data collected on plots established within the restoration area. The project scope included analyzing existing datasets that were collected in Forest Park using a Unified Monitoring Protocol (UMP) to answer three research questions: 1) what can we learn from these data regarding the effectiveness of current ivy control approaches, 2) what might we learn from these data regarding impacts on non-target plant species, and 3) what are the strengths and limitations of UMP data for assessing abundance and spatial distribution of trees species?

Q2. What are the key barriers to meeting Forest Park's ecologic management goals while providing access to Forest Park for recreation?

\section{Literature Review:}

Google Scholar and PDX Scholar searches revealed studies that documented management challenges associated with managing parks systems balancing park health with recreation demands.

Recommendations for other studies resulted from stakeholder interviews.

\section{Stakeholder interviews:}

Interviews with Kendra, Marshall and Renee revealed challenges specific to Forest Park. Dr. David Ervin recommended papers published by him and his colleagues, papers published by Dr. Robert Costanza and Dr. Lydia Olander on the topic of ecosystem services. Dr. Ervin introduced me to Dr. Olander who provided input on the approach to on my project and recommended additional sources for review. Dr. Dissanayake suggested course work in economics, and pursuit of a Certificate of Sustainability to round out my understanding of the challenges associated with managing public lands. 


\section{Course work:}

Economics courses recommended and taught by Dr. Dissanayake helped shape my understanding of the economic challenges associated with managing common pool resources namely EC 530, Resource and Environmental Economics and EC 522 Economics of Sustainability.

\section{Stakeholder workshops:}

Discussions and priorities set in the stakeholder workshops, described above, revealed Forest Park specific challenges from both a land manager and researcher point of view.

\section{Data analysis:}

The process of gathering and analyzing data through the Forest Park Restoration Effectiveness data analysis project revealed limitations in the data and resulted in recommendations for changes in data collection methods and additional approaches to gathering relevant data.

\section{Q3. Are adequate resources available to meet documented management needs? If not, why not?}

\section{Literature Review:}

Needs for resources to manage the park for resilience were gleaned from plans, reports and presentations. Google searches for historical documents on the establishment and funding for Forest Park specifically and Portland Parks in general revealed historical documents and news stories. Literature reviews on the topic of neoliberalism and austerity spending revealed some of the reasons behind shrinking municipal budgets, specifically City of Portland's budgets.

Stakeholder interviews:

Interviews with PP\&R, FPC, Dr. Dissanayake, Dr. Ervin, Dr. Olander and Dr. Dan Jaffe, Associate Professor of Sociology at PSU shaped my understanding of the core challenges for funding public parks.

\section{Course work:}

The lectures, readings, and project work I performed for Environmental Sociology, Sociology 565, taught by Dr. Jaffee helped answer the "why not" part of this question.

\section{Stakeholder workshops:}

Stakeholder workshops broadly helped inform this question, although funding was not a primary topic of these workshops. 


\section{Data analysis:}

The Forest Park Restoration Effectiveness data analysis project generally helped inform the answer to this question although it was not designed for this purpose.

Q4. What credible methods exist for assigning values to the benefits from urban forests in general, and Forest Park specifically?

\section{Literature Review:}

Google scholar revealed an extensive volume of literature focused on ecosystem service values. Relevant studies were narrowed by including search terms urban forests, health benefits, and water quality.

\section{Stakeholder interviews:}

\section{Land Managers and Researchers:}

Interviews with Kendra, Renee and Dr. Dissanayake revealed past and potential PSU studies that could help answer this question. Interviews with Dr. Bobby Cochran in his capacity as then Executive Director of Willamette Partners provided a link to a comprehensive report on health benefits from ecosystem services. An interview with Dr. Priya Kansal, cardiologist for Keizer Permanente helped inform health benefit research potential and helped define the study methodology for a blood pressure stress study in Forest Park. Data collection for my blood pressure/stress study was a planned deliverable for this project, however, my data collection was incomplete when all human research conducted by PSU was cancelled due to social distancing requirements as a response to the coronavirus. The study design and analysis methodology which was approved by PSU's Institutional Review Board (IRB) Board, Dr. Kansal, Dr. Maser and Dr. Dissanayake and Dr. Pan is included in Appendix E.

\section{Interviews with Business:}

Interviews were conducted with five Sustainability Manager from large businesses with offices in Portland: Nike, Adidas, Daimler, OHSU and the Trail Blazers. Business selections were prioritized by proximity to Forest Park or other Metro natural areas, employee counts, and business type.

\section{Course work:}

Lectures, readings and project work in EC 530 and 522 provided key information. A two-term Reading and Conference course led by Dr. Catherine de Rivera, ESM 505: Linkage Benefits, the Ecosystem Services of Habitat Connectivity, resulted in the development of a Connectivity Services Framework that has been adapted for this project. Two paper resulted from this course, both are preparation for publication: The 
ecosystem services of connectivity (Butler et al. in preparation 2020) and A framework for transformative change for functional urban ecosystems: incorporating ecosystem connectivity into planning for livable cities (Hardy et al. in preparation 2020).

Stakeholder workshops and Data Analysis:

Neither of these methods was employed to address this question.

Q5. Assuming current resources are inadequate and unsustainable, what additional or alternative sources of funding should be explored?

\section{Literature Review:}

Google scholar and Google searches revealed various funding models for urban forests and parks. One was adapted to create the Urban Forest Services Framework.

\section{Stakeholder interviews:}

New potential funding sources were explored in interviews with Kendra, Renee and Marshall. Four interviews were conducted with the Sustainability Manager from Adidas, Nike, Daimler and the Blazers. The questionnaire that guided the interviews is in Appendix A.

Course work, Stakeholder workshops and data analysis:

None of these methods was employed to address this question.

\section{Findings}

Detailed findings organized by research question are presented in this section. These findings informed development of the UFSF framework, its application to Forest Park, recommendations for funding and specific recommendations for ecological research.

\section{Q1. What are the ecological trends in Forest Park?}

Past and ongoing ecological research in Portland's Forest Park suggests that the ecosystem of the forest has been significantly altered by logging and fire, invasions by non-native species, air pollution, altered carbon and nutrient cycles, and ongoing low-level disturbance from recreation, restoration activities, and infrastructure. These disturbances and stressors result in a set of novel conditions (Addessi, 2017; Broshot ,2007; Broshot, 2011; Copp. 2014; Dresner et al., 2017). 
Current management plans developed by the City of Portland state that the aim is to manage Forest Park for a late successional forest (PP\&R and BES, 1995). Currently, ecological management is focused on restoring forest health. One of the primary activities is restoring native plant communities that have been negatively impacted by invasive plant species, including ivy (Hedera spp.), within the Balch Creek watershed (PP\&R, 2018). Ecological research suggests that the forest ecosystem has been significantly altered, resulting in novel conditions without antecedent or current reference which complicates management practices aimed at restoring forest function (Addessi 2017; Broshot 2007; Broshot 2011; Copp 2014; Dresner et al. 2017).

\section{IMPACTS OF IVY INVASION}

Extensively used hiking, biking and horseback riding trails cross through the forest with an estimated $550,000+$ visitors per year (Van Deren, 2018). Forest Park is considered a second growth forest, having been extensively logged in the 19th and 20th centuries (Copp, 2014).

Ivy (Hedera spp.) is one of the most widespread and prevalent invasive plants in many areas of Forest Park. Ivy removal has been a focus of ad hoc and volunteer efforts since the 1990s, led by the PP\&R's No Ivy League and the FPC (No Ivy League, 2018), and more recently through the focused restoration efforts by PP\&R. Recent research (Copp, 2014; Dresner, 2017) suggests that ivy is dominant or nearly so across much of the greater Balch Creek area exclusive of the areas where ivy has recently been removed. It also appears to co-occur commonly with other aggressive understory weeds such as wild clematis (Clematis virginiana) and Armenian blackberry (Rubus armeniacus) which have been observed to fill gaps when trees die based on observations in the Balch Creek area (Broshot, 2018).

English ivy is a highly invasive vine native to Europe and introduced to the United States by European settlers as an ornamental ground cover. Ivy threatens more forest types in the Pacific Northwest, reducing biodiversity by outcompeting groundcover and shrub species (Biggerstaff et al., 2007; Copp, 2014; Dlugosch, 2005; Radeloff et al., 2015. Ivy removal in Forest Park has been a focus of ad hoc and volunteer efforts since the 1990s led by the No Ivy League and the FPC (PP\&R n.d.-a).

\section{Establishment and Spread}

English ivy was introduced into Forest Park through multiple mechanisms: invasion through adjacent neighborhoods; along roads, trails and power line corridors; and was once planted in Forest Park to 
stabilize the steep (based on anecdotal information), eroding slopes destabilized from past logging, fire and storm run-off from roads (Query, personal conversation 2018; Soll, 2008). Ivy grows in a wide range of soil types and is tolerant of drought, frost and shade making it highly competitive with native plants (Soll, 2008). Ivy's high propagule pressure contributes to its ability to invade, reproducing from root-like stems, from plant fragments, and seeds that are distributed by birds (Soll, 2008).

\section{Coverage and Growth Rate}

A study conducted by ESM graduate student Sara Copp in 2014 reveals that between 2010-2013 ivy coverage on plots within Balch Creek watershed increased an average of 14 percent where total native understory increased less than 1 percent (Copp, 2014). English ivy takes advantage of increased light levels during the winter under deciduous forest canopies fueling higher growth rates in the spring (Hollway \& Rosenstiel (2013).

Reduction of Diversity and Richness - Loss of Herbaceous Layer

Observations by Copp were that both diversity and richness were reduced in plots with greater than 43.75\% ivy cover, meaning native understory negatively responds after ivy coverage reaches 44\% (Copp, 2014). In a forest community, much of the biodiversity resides in the native herbaceous plant community which serves a specific role in maintaining the structure and function in temperate forest ecosystems (Gilliam, 2007): Competition with this layer, as that from ivy, can determine the success of plants occupying higher strata including the regeneration of overstory tree species (Gilliam, 2007).

\section{A Tipping Point Observed}

The faster ivy spreads, the faster it can alter the forest ecosystem potentially reaching a point where the forest will shift to a novel state, no longer able to return to a self-sustaining forest without aggressive management. Copp identified that $44 \%$ ivy coverage is a potential tipping point for ivy after which the forest may no longer be self-regenerating (Copp, 2014). At an average rate of increase of $4.6 \%$ per year, it could take less than 10 years for ivy to reach the tipping point throughout most of Forest Park without management (Copp, 2014). It is not known currently know where ivy current exists within Forest Park and at what coverage level. The last known vegetation survey was conducted in 2011 (Johnson, personal conversation, 2018) nearly a decade ago.

\section{Bank Stabilization}

An estimated $90-95 \%$ of the upland slopes in Forest Park exceed $30 \%$ and therefore have severe potential for landslides (PP\&R, 2011). While ivy has a shallow root system, potentially offering less erosion protection than native understory species (Soll, 2008), on the slopes where ivy grows as a mat, it may protect the slopes from landslides. Removing the ivy from these locations poses a risk to the people 
removing the ivy, a risk of rocks falling on trails (Johnson, personal interview, 2018), and may result in increased erosion. Tradeoffs for removal of ivy from steep slopes must be weighed in restoration decisions (Soll, 2008).

\section{ECOLOGICAL CONDITIONS OF FOREST PARK}

Multiple studies conducted within Forest Park have recorded ecological conditions that portray a highly altered and novel ecosystem that may not result in a self-regenerating forest (Addessi, 2017; Broshot, 2007 \& 2011; Copp 2014; Dresner et al., 2017).

Tree Mortality and Lack of Tree Recruitment

Randomly selected plots along an urban-rural gradient were observed over a 10-year period. Broshot, who established and monitored these plots since 1993, observed significantly fewer live trees and significantly more dead trees in 2003 than 1993 (Broshot, 2007 \& 2011). The total number of seedlings decreased from 76 to 37 stems, and a lack of shade tolerate trees were present in the understory (Broshot, 2011). Although a forest in normal successional development could be expected to have increased mortality during a thinning stage, the loss of shade tolerant trees and lows levels of recruitment point to other, but unknown, causes (Broshot, 2011).

Lack of Shade Tolerant Trees and Seeds

Results of studies conducted by Dresner within Forest Park found that the plots throughout the study area contained few shade tolerant trees and seeds (Dresner et al., 2017). Ettinger studied seed and microsite limitation in an urban forested park in Seattle and found that natural seed production in these forests was also low (Ettinger et al. 2017).

Hardwood Species may Dominate in Balch Creek

Results of studies conducted by Dr. Dresner, and her students, comparing the urban end of Forest Park to an old-growth remnant at the rural end suggests that the urban end of Forest Park in the Balch Creek watershed will be dominated in the future by hardwood species (Dresner et al., 2017).

Lack of Coarse Woody Debris

Many areas within Forest Park lack woody debris (PP\&R 2001, Dresner et al. 2017, Myers et al. 2013). In Ettinger's urban forest plots, adding deadwood increased seedling survival whereas removing ivy did not have strong effects (Ettinger et al. 2017). 


\section{Soil Disturbance}

Soil disturbances and lack of $\mathrm{O}$ and $\mathrm{A}$ horizons were observed on plots within Forest Park studied by Dresner and her colleagues over a period of 10 years (Dresner et al. 2017). There is some evidence that invasive earthworms have also altered the soil horizons in Forest Park (Query, personal conversation, 2018).

\section{ANALYSIS OF DATA COLLECTED ON BALCH CREEK RESTORATION SITES}

Three undergraduate students from the Environmental Science and Management (ESM) Department, performed analysis on data collected from treatment plots within the Balch Creek restoration area of Forest Park and created GIS datasets and map layers for vegetation, canopy gaps, and topographic variables within the Balch Creek restoration area. The research was supervised by me, in consultation with Eric Butler, ESM graduate student studying in Forest Park, and ESM and Geography faculty, Dr. Jennifer Morse, Dr. Jeff Gerwing and Dr. Andres Holz. The research questions we hoped to answer by analyzing the monitoring data were:

1. Are the UMP data collection points for the Balch area representative of the area?

2. How effective is treatment for removing ivy in the short and long term?

3. What are the strengths and limitations of UMP data for assessing the abundance and spatial distribution of tree regeneration and coarse woody debris?

4. What do we know about the impacts (positive or negative) of ivy treatment on non-target species?

5. How effective are current replanting strategies?

6. What factors determine where ivy occurs in Forest Park and what effects does it have on the understory plant community?

Due to limitations of the data available, the type of data collected and the absence of control plots, only a few conclusions were reached. Figure 5 shows the locations of the treatment areas within the Balch Creek Watershed of Forest Park. Analysis of the Uniform Monitoring Protocol (UMP) data from the Balch Creek treatment area indicates that ivy management reduced ivy abundance in the Balch I UMP plots by an average of 19.76\% between 2015 (pre-treatment) and 2016 (1 year post-treatment), however, inconsistencies in recording prior and ongoing restoration activities in this area, and lack of control plots are confounding factors in this analysis. No data was recorded on what type of vegetation was planted on these plots as part of the restoration efforts, for example, so data from these study plots do not inform replanting efficacy. 


\section{Balch Creek Treatment Areas}

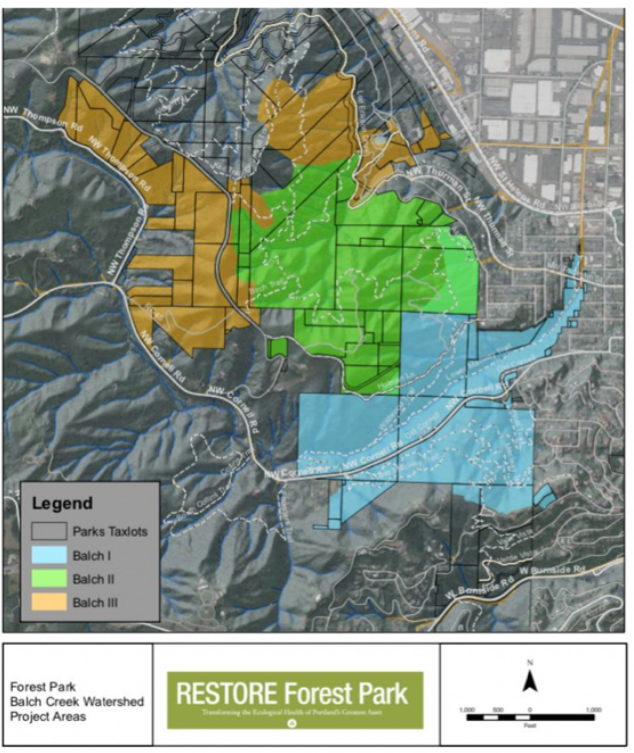

Figure 5. Map of the treatment areas within the Balch Creek Watershed in Forest Park.

The team recommends further monitoring of the UMP points and permanent research plots established by researches to determine the growth trends of ivy and other vegetation. Control sites are necessary to determine the effects of further ivy treatment and revegetation. Monitoring plots established prior to further treatment should be reorganized to be more representative of the topographic wetness index (TWI) of the area. Methods for measuring coarse woody debris and tree regeneration should be modified to better represent site conditions and produce data more useful for scientific analysis.

While the UMP monitoring data may be useful for general trends in ivy and vegetation growth, we advise ongoing scientific studies in parallel with ongoing restoration activities in order to answer the questions about what is impacting successional trends in Forest Park and what restoration methodologies are most effective in restoring forest health. Future prioritized research topics recommended based on this analysis of the UMP date include: determining the effects of invasive species treatment on non-target vegetation on Balch I plots using UMP data, georeferencing vegetation and other data on the Balch Creek permanent research plots, mapping vegetation and canopy gaps for all of Forest Park using the methodology employed for Balch Creek, mapping the perimeter of ivy invasions on the ground, estimating percentage ivy cover, establishing long-term protected research plots to study soils and revegetation and tree regeneration strategies (Hardy et al. 2018 unpublished paper). A link to the full report is provided in Appendix F. 


\section{PERCEIVED LIMITATIONS OF RESEARCH}

PP\&R ecologists note that they were not directly involved in the study design, data collection and data analysis processes of the studies referenced above and have questions about validity of the findings (Petersen-Morgan, personal conversation, 2018; Johnson, personal conversation, 2018). The studies referenced in this paper represent the only known long-term science-based ecological studies conducted within Forest Park based on a comprehensive review of literature and stakeholder interviews. Observations are consistent across the studies. An outcome of the stakeholder workshops is a recommendation to establish a more formal ecological research program between land managers and researchers. Comprehensive recommendations for future research are included later in this report.

\section{Q2. What are the key barriers to achieving ecological management goals for Forest Park? while providing access to Forest Park for recreation?}

Two key barriers exist to meeting Forest's Parks management goals: 1) lack of data to adequately inform management plans and set priorities, and 2) general lack of funding to support management and research. As noted in the introduction, these are the two most common barriers to managing urban forests in the US (Pergitzer et al. 2012).

Outstanding research questions and need for assessments were compiled from stakeholder workshops, the Forest Park Ecological Prescriptions document (PP\&R 2011), and research projects conducted by PSU students and faculty (Hardy et al. unpublished paper 2018, Hardy et al, unpublished paper 2019) are:

1) What is the Impact of air pollutants on forest health?

2) What is the current stand trajectory, and how will it be impacted by recreation and climate change?

3) Forest disease assessment.

4) Wildlife use and needs assessment.

5) Rare plant distribution.

6) Wetlands documentation.

7) Where ivy exists today and where it is spreading?

8) Impacts of trampling.

9) Impacts of herbicide treatment on soils and plant regrowth.

Data gathered in Forest Park by various researchers is scattered and difficult to locate. A key initiative resulting from the Stakeholder Workshops is to collect, cleanse and post data on a publicly accessible data visualization platform. Some data was collected and posted on NODE in 2019, but it became clear 
through the initial collection process that the work required to locate, cleanse and post the data was significant. A grant proposal to formally establish the Forest Park Research Consortium, a collaboration between FPC, PSU/ISS, and PP\&R was submitted to OWEB in the fall 2019. The grant proposal was supported by Renee Myers, Executive Director FPC; Todd Rosenstiel, Assistant Dean CLAS PSU, Fletcher Beaudoin, Director ISS; and Adena Long, Director PP\&R. OWEB staff recommended the project to the OWEB Board in January 2020, but six other projects were awarded the available funds allocated for this grant. A link to the grant proposal can be found in Appendix D. I recommend that some form of this proposal be resubmitted to OWEB or another entity to continue to move this research initiative forward.

\section{Q3. Are adequate resources available to meet management needs for PP\&R and/or FPC? If not, why not?}

The consensus among all people I interviewed, affirmed by a 2019 presentation by PP\&R and acknowledgement by Mayor Wheeler, is that the answer to this question is a resounding "no", adequate resources are not available to meet the needs for PP\&R. Likely securing funding for PP\&R will become more challenging in the near future with the City of Portland facing economic deficits as a result of the coronavirus which is projected to cause a $\$ 7$ million to $\$ 75$ million budget deficit for the City of Portland in 2020-21 (City of Portland, 8 May 2020). Funding for FPC operations and projects may also prove more difficult to secure with predictions of an economic recession and continued high unemployment rates.

While today's funding challenges are unique to the times, lack of adequate funding to manage Portland parks has been a chronic issue since the park's bureau was first established.

\section{Historical and Chronic Underfunding of Portland's City Parks}

While the people of Portland recognized early on the value of protecting park land within the city, the early processes of planning for and securing park land was haphazard and relied primarily on public donation of lands (PP\&R 2010). In 1900 Portland voted to establish the first park district following the Oregon legislative approval for cities to levy property taxes to develop parks (PP\&R, 2010).

Throughout the $20^{\text {th }}$ century, the funding for Portland public services, including parks, varied significantly depending on the political-economic policies and leadership at the time, relying primarily on income and property tax as funding sources, supplemented periodically by bond measures which dedicated funds to 
parks for limited time periods (PP\&R 2010). Property tax limitation measures voted in during the 1990s and corporate tax reductions appear to have had the most significant negative impact on parks funding. As is true today and throughout Portland's history, Portland's parks compete with safety and housing for general fund monies (Templeton 2019).

\section{Impacts of Property Tax Limitation}

Oregon was highlighted in 2018 as one of four states significantly impacted by property tax limitations, resulting in local communities' inability to fund schools and other services (Hauser 2018). Property taxes in Oregon began to fall steeply in 1990 when the voters approved Measure 5, the first of three property tax restrictions put in place prior to 2000. Since property taxes were the primary source of funding for schools, Measure 5 hit the school system the hardest, but also negatively impacted funding for libraries, parks and public safety, and other public services (Hauser 2018).

In Oregon, property taxes fell from 4.7\% of personal income in 1990 to 3.2\% in 2015, nearly a one-third drop, according to a 2018 report from the Center on Budget and Policy (Center on Budget and Policy, 2018), a non-partisan research institute in Washington D.C. State and federal funding also declined as a share of local revenue, the case in Portland, forcing them to look for other sources of funding to pay for services - or to cut services. Local governments turned to fees to make up the gap. In 1977, fees and charges made up $16.7 \%$ of all revenue of local governments in Oregon. By 2015, that share had risen to 26.6\%. Fees hit low income people harder because fees represent a larger portion of their income. For example, a $\$ 50$ fee to participate in a school band is harder to pay for a parent working at minimum wage than for higher income families. Meanwhile, higher-income individuals benefited from the percentage reduction of property tax on high value properties (Hauser 2018).

In 1997, Oregon enacted Measure 50 (which clarified a similar Measure 49 approved by voters in 1996), severed property taxes from real market values and tied it to an assessed value which set the starting assessed value of a property at its 1995 value discounted by 10\%. Additionally, Measure 50 limited increases to no more than 3\% annually. This benefited primarily high-income families and businesses and significantly negatively impacted city and state budgets (Figure 6). 


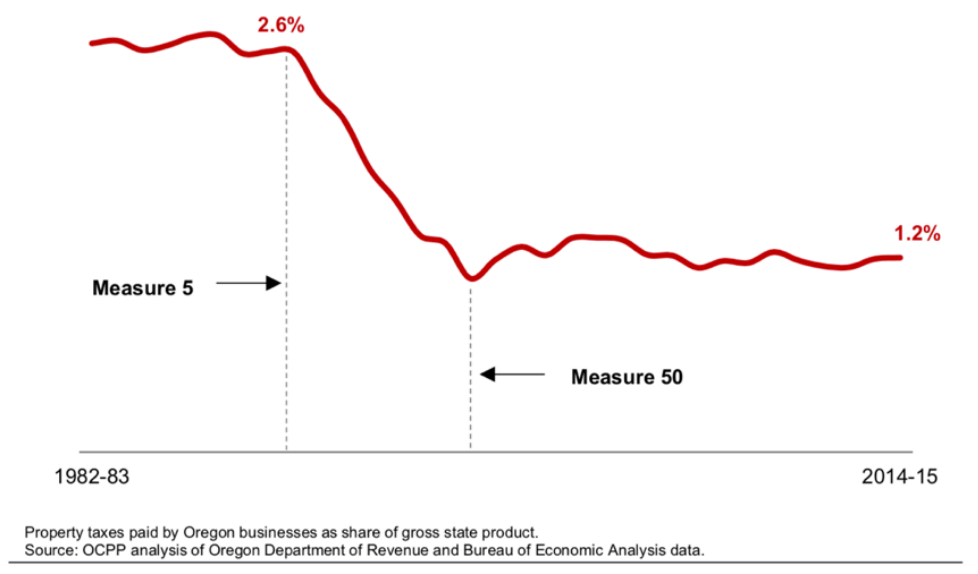

Figure 6. Impact of Measure 5 and Measure 50 shown as property taxes paid by Oregon businesses as a share of gross state profits.

\section{Impact of Corporate Taxes Limitations}

Taxes on corporations in Oregon have historically been low. In 1929 the Oregon Legislative established Oregon's corporate income tax and set a \$25 minimum tax to do business in Oregon, which was lowered in 1931 to \$10 a year. In 2010 voters approved a new corporate minimum tax structure when Measure 67 was enacted. Measure 67 established a new minimum corporate tax rates of $\$ 150$ for S-C Corps and Partnerships, C-Corp minimum rate starting at $\$ 150$ with Oregon sales less than $\$ 500,000$ with graduated increases up to $\$ 100,000$ for C-Corps with sales more than $\$ 100$ million. And, Measure 67 established a new corporate income tax rate structure which retains $6.6 \%$ on the first $\$ 250,000$ of net income and established a new marginal rate of 7.6\% on net incomes above $\$ 10$ million (Sheketoff, 2017).

In the 1973-75 budget period, corporations paid 18.5\% of all Oregon income taxes. In 2016 they paid $6.7 \%$ a decline of nearly two thirds. Profits from the Oregon Lottery contribute more than corporate tax revenue with the profits funding schools, the State Parks system and watershed enhancements projects through Oregon Watershed Enhancement Board (OWEB) and other programs. The Lottery system channels public money to specific projects to backfill the state's shrinking budget. Some profitable corporations have paid very little in Oregon income tax. According to OCPP (Mac Innes \& Ordonez 2016) in 2013,55 corporations with sales over $\$ 100$ million used tax credits to pay less than the minimum tax. The phenomenon of big corporations paying next to nothing is not unique to Oregon. Sixty-eight (68) Fortune 500 companies paid no state income taxes in least one year from 2008-2010, despite collectively 
reporting nearly $\$ 117$ billion in pre-tax profits to their shareholders during that period. Some managed to pay no income taxes over that three-year period including Intel, one of Oregon's largest employers (Mac Innes \& Ordenez 2016). In 2017 Nike's tax rate was decreasing, despite steadily increasing sales, their net contribution to Oregon decreased (Figure 7).

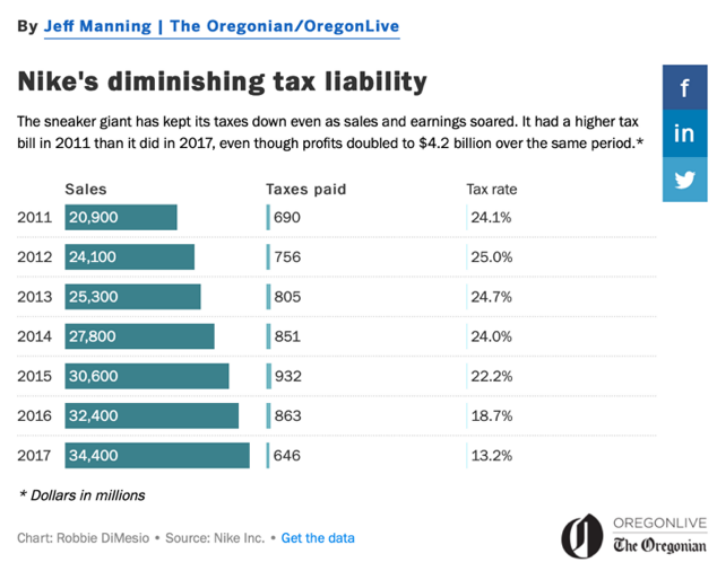

Figure 7. Nike's business tax contribution in 2017 decreases as sales climb

From the mid 1970s on, the corporate share of state income tax declined and is predicted to continue to decline without intervention from the government (Figure 8). Measure 50 locked in a lower property tax rate for business property relative to residential property, reducing the share of corporate property tax revenue. Corporate income taxes have been reduced, resulting in a steep decline in the percentage of corporate income tax as a percent of all Oregon income tax collected. Corporate tax lobbyists claim that lowering state corporate income taxes will produce economic growth because companies will have more money to invest. However, Michael Leachman of the Oregon Center for Public Policy (Leachman, 2006) disagrees. He reports that state and local taxes represent a very small part of the costs of business ( 0.8 percent) and therefore likely have little effect on a corporation's ability to invest. Businesses are more concerned about proximity of their markets and suppliers as well as the quality and cost of labor, utilities, transportation and communications infrastructures. If lowering income taxes results in reductions in the quality and quantity of public investments, the impact of lower taxes may be to slow economic growth, not increase it (Leachman, 2006). Oregon was tied for the lowest tax rate in the US (Figure 9) in 2014. 


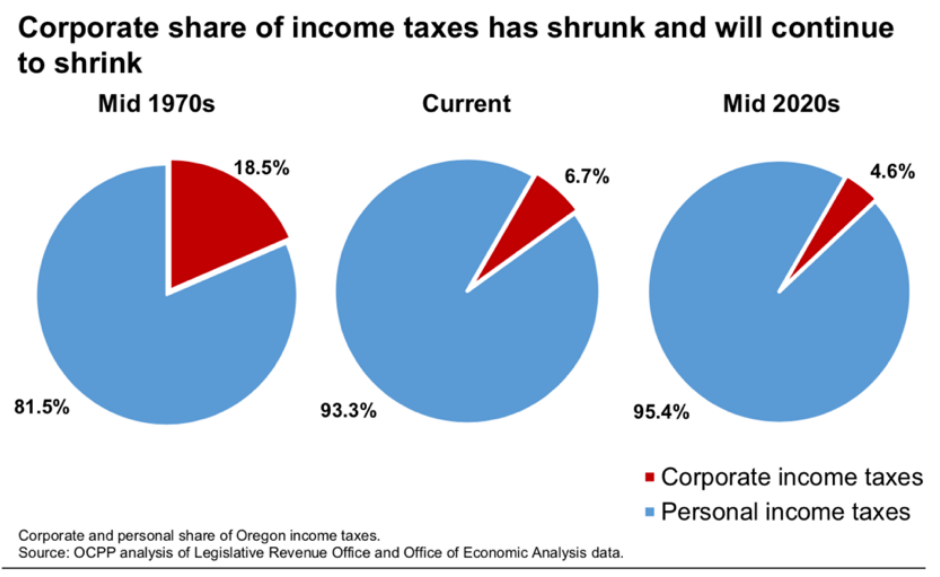

Figure 8. Corporate and personal share of Oregon income taxes

\section{Oregon's business taxes tied for lowest}

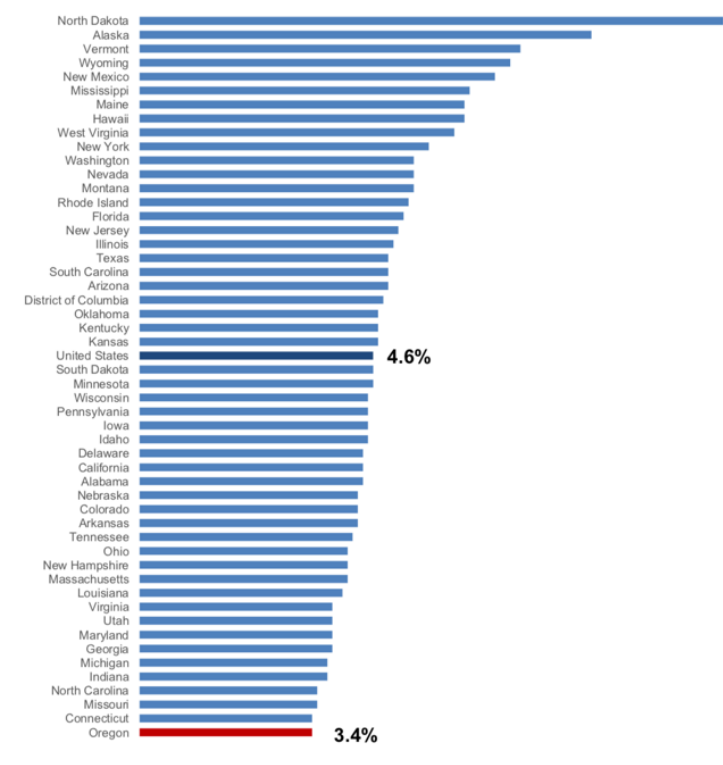

Fiscal year 2014 state and local business taxes as a share of private sector GSP by state.
Source: OCPP presentation of Council on State Taxation data. Source :

Figure 9. Fiscal year 2014 state and local business taxes as a share of private sector GDP by state.

In response to concern over the low corporate tax rates in Oregon, in May 2019, Oregon voters approved a new $0.57 \%$ tax on Oregon gross receipts above $\$ 1$ million that is went into effect in 2020 . The tax is expected to raise $\$ 1.4$ billion per year. Likely those funds will be used to backfill state budget deficits from the response to the coronavirus.

\section{Current Funding Challenges}

For the 2019-20 budget year, PP\&R was directed by Mayor Ted Wheeler to once again reduce its budget. As reported by OPB (Templeton 2019), PP\&R personnel costs have been rising for the past several years. 
The cost of salaries, health benefits, labor agreements and public employee pensions (PERS) have increased significantly (Figure 10). For the past several years, PP\&R has balanced its budget with hiring freezes and other temporary measures, even as the gap between its revenue and costs widened. This led to a $\$ 6.3$ million deficit in a roughly $\$ 94$ million operating budget leaving PP\&R to propose laying 56 people, among other cuts. Mayor Wheeler says that it will be hard to free up general fund dollars to invest in the parks system, given how much the city now spends annually on homeless services and public safety (Templeton 2019) with Wheeler suggesting the formation of a Parks District funded by a new public tax.

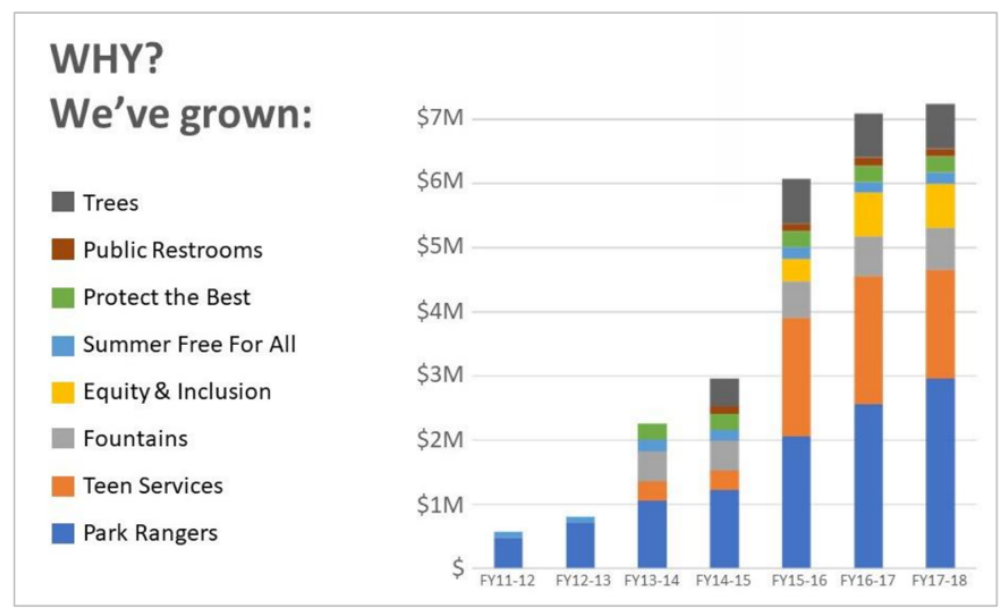

Figure 10. PP\&R Distribution of Expenses February 4, 2019 (PP\&R, n.d.-a)

In 2020-21 the City of Portland projects a \$7 million to \$75 million budget shortfall (City of Portland, 8 May 2020) which will result in cuts to programs and as yet unspecified impact on funding for Forest Park restoration and management programs.

\section{Q4. What credible methods exist for assigning values to the benefits from urban forests in general, and Forest Park specifically?}

Multiple methods exist to assess the values of ecosystem services. Here I briefly explore five methods and their potential value in assessing benefits from urban forests. Several methods have been used in the past to assess benefits from Forest Park. The results and relative usefulness are discussed. The usefulness of these methods is limited if they can only provide a snapshot of value rather than reflect trends in values of ecosystem services. A cost-benefit analysis for management actions requires a baseline of ecosystem services and a trend for those services and evidence that management actions are effective in protecting 
services. This type of data is lacking for Forest Park. See Research Recommendations included later in this report.

\section{Travel Cost}

The travel-cost method provides an inexpensive way to estimate the value of recreation by estimating people's willingness to pay for visiting a site. The value derived come from the number of trips people make and the cost of their travel. One study designed to estimate the recreation value of Forest Park was conducted in 2015 by a team of PSU researchers using visitor data provided by PP\&R. Based on the opportunity cost of visitors' time and the estimated cost of travel and the data supplied by PP\&R, an average value per visit of $\$ 240$ and an annual value of $\$ 31$ million was estimated (Bluffstone et al., 2015). Researchers who participated in the study note that this estimate may be high, but also note that other values of recreation are not included in this analysis (Bluffstone et al., 2015) so the total value is low.

\section{Hedonic Pricing}

The hedonic pricing method uses the value of a surrogate goods or services to measure the price of a non-market good. For example, housing prices can be used to provide the value of a particular environmental attribute like tree canopy. Two hedonic pricing studies conducted in Portland reveal that the presence of urban trees have a positive impact on housing values and decrease time to market. A 2009 study by Donovan and Butry finds that on average, street trees add $\$ 8,870$ to single-family residential home sales prices and reduces time to market by 1.7 days (Donovan \& Butry, 2009). Similarly, a study conducted in 2015 by Netusil et al. concludes that the average benefit of large patches of tree canopy within $1 / 4$ miles of a single-family residence in Portland is between .75 and 2.52 of the mean saleprice. The authors note there is a diminishing return past a certain level of tree canopy potentially because trees can block valued views particularly in Portland's west hills (Netusil et al. 2016). These studies provide an estimation of people's willingness to pay to live next to trees which is useful when seeking funding options to maintain trees. Donovan and Butry note that, in Portland, the responsibility for maintaining street trees in neighborhoods falls mostly to private landowners who may or may not actively maintain them. The authors conclude that to prevent an under-investment, the City of Portland may need to bear a larger proportion of the cost to maintain street trees (Donovan \& Butry, 2009). This observation supports the thesis that the City of Portland underinvests in the maintenance of trees in general including those in natural areas like Forest Park.

\section{Benefit Transfer}

A benefit transfer method is used to estimate the economic value of ecosystem services by transferring available information from studies conducted in similar locations. In 2018, Earth Economics conducted a 
limited, preliminary assessment of benefits from Forest Park using this method. The limited analysis finds that Forest Park supports ecosystem services between $\$ 8$ and $\$ 20$ million each year, that the area around Forest Park, designated as the greater Forest Park Conservation Area, plus Forest Park supports \$21 to $\$ 54$ million worth of ecosystem services per year (Van Deren 2018). Additionally, the report estimates the park supports $\$ 18.9$ million worth of recreation benefits and increases property values surrounding the park by $\$ 34.1$ million (Van Deren, 2018). The accuracy of these numbers is limited by the data available for Forest Park. The vegetation data used for analysis does not reflect current conditions as it was collected in 2011. Only a high-level tree inventory / condition assessment for Forest Park has been conducted. In speaking with Matt Van Deren of Earth Economics, their ecosystem services estimate does not include health benefit from recreation which can be assessed separately and added to these totals (Van Deren, personal conversation, 2018). Without up to date primary data, and vegetation trends, this type of study is limited in its usefulness in identifying management actions needed to restore ecosystem function, and likely significantly undervalues the services provided by Forest Park.

\section{Contingent Valuation - Focus Groups and Choice Experiments}

Focus groups and choice experiments are used to understand people's willingness to pay for various attributes of nature. In 2016, researchers from PSU worked with PP\&R and FPC to conduct focus group of the perceived value of ecosystem services from Forest Park. The aim of the focus groups was to lay a foundation for a contingent value and choice experiment seeking to understand people's willingness to pay for improving services from Forest Park. Results of the focus groups show that health of the ecosystem and recreational experiences are the most important to respondents (Barreyro et al. 2016). Phase 2 of this study, a choice experiment, has been designed and tentatively approved by PP\&R and FPC, which would broadly assess the value of ecosystem services delivered by Forest Park and other parks managed by the City of Portland rather than just focus on benefits from Forest Park (Dissanayake \& Myers, personal conversations 2017, 2018, 2019). Having been involved in discussion about this project since 2017, my original intent was to include the results of this survey in this project report, but, the survey has not yet been fielded due to lack of funding. Ideally the final study would include questions about people's willingness to pay higher property taxes, income taxes, and other taxes and fees to support an independent Parks district with funding for FPC. I recommend that this research study be fielded when financially feasible.

\section{Causal Chains and Benefit Relevant Indicators}

My assessment of the values from urban forests, and Forest Park specifically, builds on the ecosystem services research conducted at Duke university and led by Dr. Lydia Olander. Olander et al. maintain that 
current assessments of ecosystem services often exclude services that are difficult to measure either because there is a of lack of data, perceived lack of credibility for non-market services or both (Olander et al. 2018). To address this, Olander and her team developed a new indicator which they term Benefit Relevant Indicator (BRI) (Olander et al. 2018). Their method uses causal chains to link management actions that result in a change in ecosystem function causing a change in ecosystem service, or BRI, defined in terms of a societal benefit (Olander et al. 2018). BRIs provide a way for stakeholders to identify which benefits and values are important to them in terms that are specific and measurable without the need for monetization and markets for ecosystem services. A BRI can be value itself like a decrease in nitrous oxide (NOx) a toxic air pollutant. A BRI can also be translated into a market value if the data is available. As noted above, Rao et al. estimate that the $\mathrm{NO}_{2}$ reduction from the current tree canopy in Portland, Oregon could result in a lower rate of respiratory illness providing a \$7 million annual benefit (Rao et al. 2014). Importantly, Rao et al. point out that an increase in tree canopy could increase this benefit and value (Rao et al. 2014).

Insurance Value of Ecosystems

In 2016, Tom L. Green and colleagues recommended that urban authorities consider the "insurance value" of ecosystems when making decisions about resource allocation (Green et al, 2016). The authors recommend against monetary evaluations of insurance values, but instead urge decisions makers to consider the investments made in urban ecosystems, or green infrastructure, to be like purchasing insurance. By investing in management strategies and actions that maintain or enhance ecosystem resilience to external disturbances, cities are better able to provide insurance for social-ecological systems (Green et al. 2016). Baumgartner and Strunz note that by investing in actions that keep ecosystems within a desired range of function, they are more resilient to catastrophic and irreversible reductions in ecosystem services (Baumgartner \& Strunz, 2014) which can occur from extreme climate events. Guided by these views, investing in management actions that restores forest function in Forest Park should be considered as insurance against a potential regime shift which would drastically reduce ecosystem services that contribute to the welfare Portland as is demonstrated by the UFSF case study. 


\section{Q5. Assuming current resources are inadequate and unsustainable, what additional or alternative sources of funding should be considered to conserve and restore Forest Park?}

Two examples of sustainable parks districts are the Tualatin Hills Parks and Recreation District (THPRD) in Washington County, and the East Bay Regional Parks District (EBRPD) in the East Bay of San Francisco. EBRPD has been in operation since 1934 (EBRPD, n.d.-a), and THPRD in operation since 1955 (THPRD, n.d.-a).

As of 2020, EBRPD includes 124,909 acres with 73 parks and over 1,330 miles of trails. Some of these parks are wilderness areas, others provide for swimming, boating and camping. More than 200 miles of paved trails through urban areas link the parks together (EBRPD, n.d.-a). According to their website, 12\% of their revenue comes from charges for services (fees), $2 \%$ from operating grants and contributions, $2 \%$ from capital grants and contributions, $69 \%$ from property tax and $15 \%$ from a property tax obligation bond (EBRPD, 2019).

As of 2020, THPRD offers thousands of classes, has 95 park sites, 70 miles of trails, eight swim centers, six recreation centers and 1,500 acres of natural areas. Founded in 1955, THPRD is a special park and recreation service district funded primarily by property taxes and program fees with a permanent local tax rate of $\$ 1.3073 / \$ 1000$ of assessed value. Its service area spans the City of Beaverton and many unincorporated areas of eastern Washington County. Its Operating Budget for 2019 was $\$ 62.6$ million.

Since its inception, the funding for Portland's parks depended on primarily on property tax revenue (PP\&R, 2010), yet the funds were never dedicated solely to parks, instead competing for general fund revenue with other demands on the City of Portland's municipal budget. It is recommended that a separate Portland Parks District supported by a variety of dedicated taxes and fees be created. Details of the recommendation are included below. 


\section{Summary of Interviews with Portland Area Businesses}

In May 2018, I conducted interviews with Sustainability Managers of five businesses of interest. Businesses were selected based on an analysis of proximity to Forest Park and other Metro natural areas and high employee counts. A map of targeted businesses is shown in Figure 11. I attempted to secure interviews with the businesses ranked 1-3 by employee count and proximity, but was unable to get an interview with Intel, Columbia Sportswear or Precision Cast Parts. Summarized below are key findings from interviews with Adidas, Nike, Daimler and the Trail Blazers. Although the Trail Blazers have a relatively low employee count, they are active in supporting the Portland community and known for having solid sustainability practices.

I spoke with an HR Manager at OHSU who indicated their organization was just beginning to develop sustainability strategies and weren't prepared to answer my questions. With over 16,000 employees and close proximity to Marquam Nature Park, further conversations with OHSU are warranted to explore funding opportunities for projects in this natural area. Multiple studies find that visiting and viewing landscapes at hospitals speeds up patient recovery and help's hospital staff recover from mental fatigue (Chang \& Chen 2017), so there is a direct value to OHSU's business from the proximity to Marquam Nature Park.

Each person interviewed agreed that businesses should invest in sustainability to protect the environment. Nike and Adidas note their sustainability programs are focused on reducing their carbon footprint particularly in their supply chain. Adidas focuses specifically on reducing plastic in the oceans. The Blazers focus on sustainability practices within their facility including their food and beverage services. Daimler focuses on technology that reduces impact from the transportation sector by designing and engineering more efficient engines and trucks. All consider funding of local conservation initiative to fall under the category of philanthropy rather than sustainability. 


\section{Portland Business Targets for Restoration Partnerships}

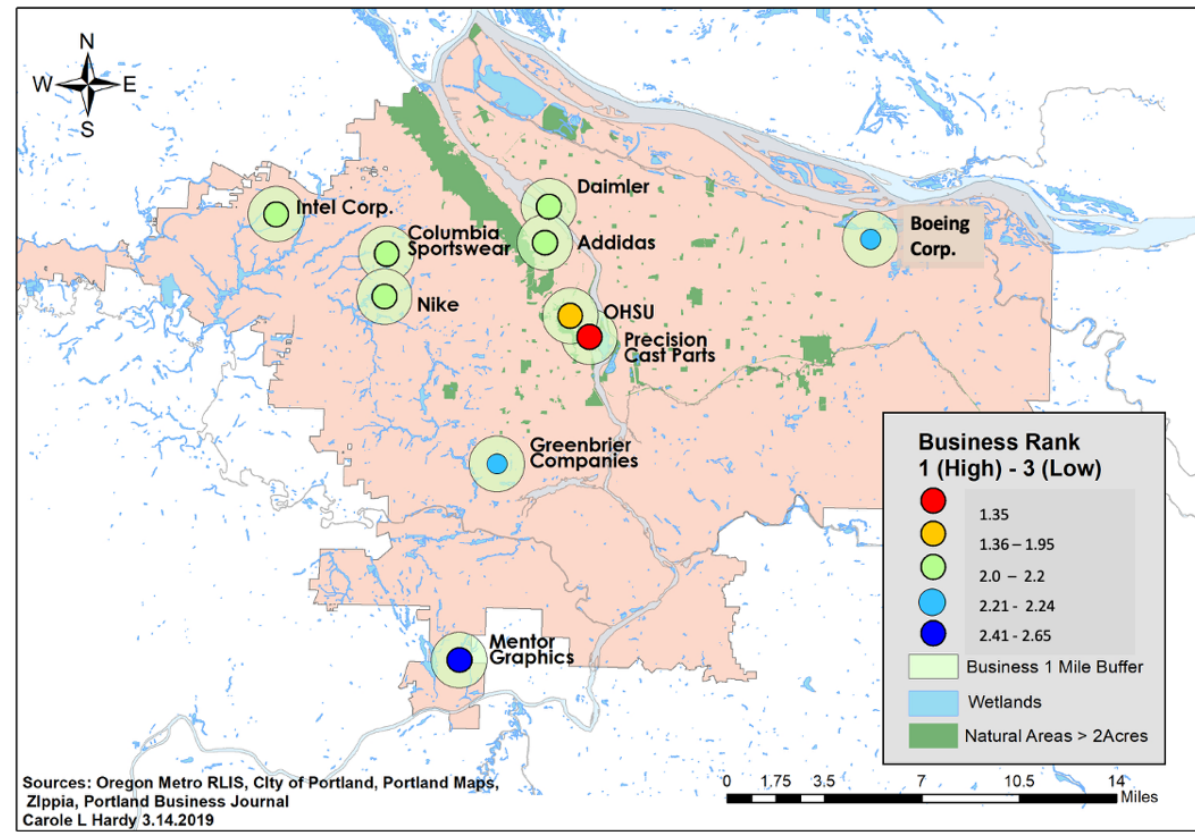

Figure 11. This map of the Portland Metro area shows locations of businesses that have high employee counts ranked by color and shows their proximity to natural areas or other types of green spaces. The light green circle around the business represents a 1-mile buffer.

Adidas' and Blazers' philanthropical programs are primarily sports related and focus on underserved children. Daimler's community programs are varied but their focus is on educational programs particularly those focused on STEM programs. Nike's philanthropic programs primarily have a global focus though they are the title sponsor of Portland's Biketown bike-sharing program managed by Portland's Bureau of Transportation (PBOT).

The most relevant finding was a 100\% affirmative and enthusiast response to the question: "Do you believe there is value in supporting or investing in the natural environment because it benefits your employees?" Karen Solomonides, Sustainability Manager for Adidas believes that exercise helps people focus which increases productivity stating, "people restore themselves in a natural environment" (Solomonides, personal conversation 2018). Solomonides also noted that they take their colleagues and clients to Forest Park when they are in town and that Forest Park is part of the Portland community. While not quantified, FPC staff observe that Nike shares a similar practice enjoying high use of the park's trails (Myers, personal conversation, 2018).

The benefits delivered by Forest Park to these organizations were ranked as follows:

1. Employee physical health from clean air and water and access to recreation

2. Employee mental health and aesthetics and recreation 
3. Attracting workforce to Portland - Adidas spokesperson said that the people who come to work in Portland like the outdoors "preferring drinking their whiskey out of a flask by the campfire than going to a fancy bar."

4. Retaining employees

5. Attracting workforce to your organization

None of the respondents were surprised the estimated value of services delivered annually by Forest Park is upwards of $\$ 200$ million, nor that it may take $\$ 1-\$ 5+$ million annually to maintain the benefits delivered by Forest Park. In fact, all perceived both values to be low. All expressed concern that these levels of investments are not currently being made.

Suggestions for programs that may interest these companies include employee donation programs with corporation match, although the amount of money available through a short-term donation campaign is limited. Even if everyone on the Adidas campus gave $\$ 2$, for example, that would only be $\$ 5,000$ and with a corporate match, $\$ 10,000$. Adidas and Daimler were interested in employee volunteer programs offered in Forest Park. Daimler and Adidas both supported the ideas of a business competition to raise funds. Both companies suggested that presentations be aimed at HR departments focusing on benefits to employees and employee health and performance.

\section{Urban Forest Services Framework}

The following section details the tools and processes of the Urban Forest Services Framework (UFSF). The UFSF framework aligns management actions with changes in ecosystem function resulting in changes in ecosystem services (benefits from nature) that produce societal values. This section first describes the USFS as a general framework, then applies it to a case study for Forest Park.

\section{General UFSF Framework}

To address the need for assigning non-market values associated with management actions that protect urban forests from disturbances that decrease ecosystem flows, I developed the novel Urban Forest Services Framework (UFSF). The UFSF aligns benefits derived from management actions that improve ecosystem functions and ecosystem service delivery from urban forests. Further it aligns benefits with beneficiaries aiding in the identification of potential sources of funding for management programs. 
The UFSF establishes a framework for identifying and analyzing linkages and dependencies between natural and human systems. It provides a tool for urban planners and natural resource practitioners to integrate connectivity into urban planning via inclusive stakeholder engagement in a way that offers an alternative to strict monetary valuation of the services. Ultimately, it provides a process and tools that help identify multiple and overlapping benefits from management actions that result in more equitable, resilient and sustainable cities that support people and biodiversity by protecting urban forest lands.

Hence, the UFSF provides a way for planners to identify values associated with management actions in terms of ecological and societal benefits using a process of deliberative valuation (Green et al, 2019). Deliberative valuation refers interactive group discussions that result in ranking and prioritizing conservation and restoration initiatives based on agreed upon values of nature's benefits. Unlike software tools like InVEST and ARIES, which use top-down approaches to incorporate ES values at a landscape level, the UFSF framework guides a systematic approach to community-engaged land-use planning that prioritizes localized societal needs. A simplified overview of the UFSF is shown in Figure 12.

Goals and actions are compiled from an existing strategic plan for conservation or restoration for an urban forest and are captured in the Urban Forest Benefits Matrix. Urban Forest Causal Chains are developed to identify benefits and societal values resulting from the management actions. The matrix is completed by cataloging the co-benefits of each action. Benefits are then mapped to beneficiaries then mapped to potential resource and funding sources. The process of populating the UFSF should be iterative and can begin by identifying goals and actions, or begin by identifying desired societal, ecological and/or economic outcomes and the actions needed to achieve the outcomes. 


\section{Urban Forest Services Framework}

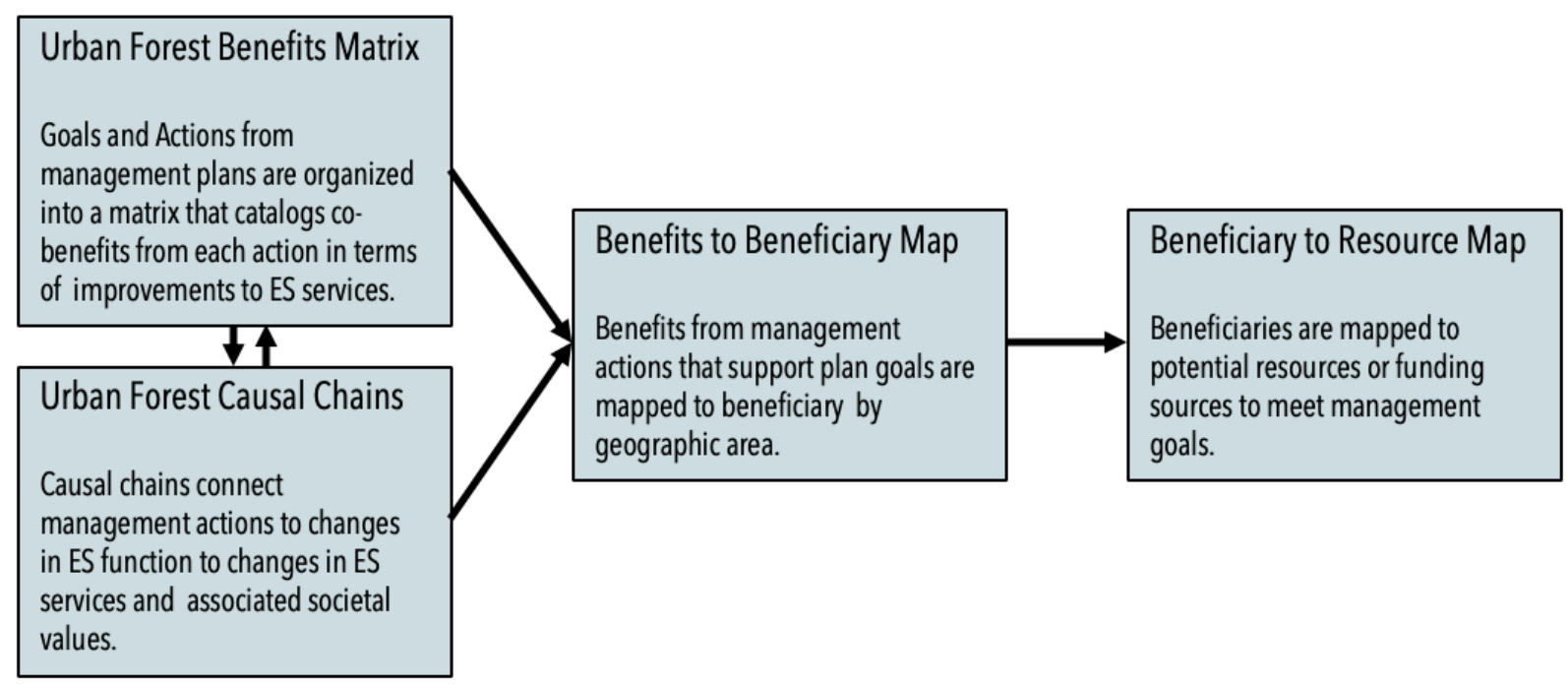

Figure 12. A simplified overview of the UFSF is shown here. Goals and Actions would first be identified and captured in the Urban Forest Benefits Matrix, then Urban Forest Causal Chains are developed to identify benefits and societal values resulting from the actions. The matrix is completed by cataloging the co-benefits of each action in the Benefits to Beneficiary Map. Benefits are then mapped to potential resource/funding sources in the Beneficiary to Resource Map.

Positive changes in ES functions or BRIs (benefits) are organized in the UFSF under the three dimensions of sustainable development, social, environmental and economic plus the broader benefit of climate regulation. The conceptual visualization of the dimensions of sustainability that is most commonly appears in various types of literature, presents a balance among these three attributes as shown in Figure 13. It is believed that the concept of the three dimensions or pillars originated in the Our Common Future, a publication commonly known as the Brundtland Report commissioned by The World Commission on Environment and Development. The report defines sustainable development as development that provides for the needs of today's societies without compromising the opportunities for societies in the future to meet their needs (Brundtland et al., 1987). 


\section{Dimensions of Sustainable Development}

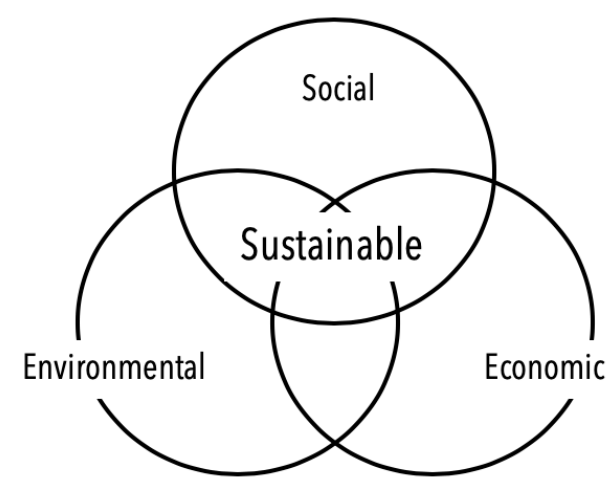

Figure 13. Sustainable development requires a balance among social sustainability, economic sustainability and environmental sustainability. This type of figure is commonly used in literature to visualize the balance among the three.

\section{USFS APPLIED TO CASE STUDY OF FOREST PARK}

For this case study, goals for managing Forest Park are guided by the Portland 2035 Plan (Bureau of Planning \& Sustainability, 2018), GFPCI (Myers, 2013), Forest Park Ecological Prescriptions (PP\&R, 2011 ). Management actions to achieve these goals were prioritized in the West side Natural Area stakeholder workshops. To build support for funding for Forest Park, the UFSF demonstrates the multiple and overlapping values resulting from these actions.

\section{Identifying Goals and Prioritizing Actions for Forest Park}

High level goals / objectives for the Forest Park UFSF support objectives from Portland's 2035 Comprehensive Plan published by Portland's Bureau of Sustainability and Planning (BSP) (BSP, 2018) as listed in Table 1, the City of Portland and Multnomah County's Climate Change Preparation Strategy (City of Portland and Multnomah County, 2014) as listed in Table 2, and the goals from the Greater Forest Park Conservation Plan (Myers et al. 2013) as listed in Table 3.

Actions identified in the UFSF for Forest Park were compiled from the GFPCl (Meyer et al. 2013) and Forest Park Ecological Prescriptions document (PP\&R 2001) and prioritized through stakeholder workshops. These actions support 9 or 10 of the 2035 Comprehensive Plan Objectives to protect the environment and watershed health (Table 1), and most of the objectives in the Climate Change Preparation Strategy (Table 2) specifically Objective 4 which states: "Seek to keep natural areas, especially urban streams, cooler including increasing the width of vegetation along streams and ensuring existing and new rules support wetlands and surface water temperature needs. Increase the ability of plantings 
(natural areas, restoration sites, green streets, ecoroofs, etc.) to withstand drought conditions. Address invasive species, connect habitats and support birds, amphibians and other species needing to alter their range" (pg. 6, City of Portland \& Multnomah County, 2014).

Forest Park provides shelter from heat, but it does not meet the objective of decreasing the urban heat island in the areas of the city that have been identified as most vulnerable. Metro's Nature in Neighborhoods initiatives strives to more directly address this issue (Metro, n.d.-a) as do other City of Portland initiatives that are not detailed in this report. As emphasized by city land managers in interviews and stakeholder workshops, equitable access to parks is a city-wide priority that will require significant investment in addition to funds required to support the resilience of Forest Park and other natural areas. FPC supports equity through their workforce training, education and stewardship programs. The current Forest Park management plans do not specifically address wildfire management; however, PP\&R is currently working with FEMA on a plan to minimize risk of wildfire within Forest Park. Results from the study are pending (Johnson, personal conversation, 2018).

\section{Table 1: Objectives to Protect the Environment and Watershed Health from} Portland's 2035 Comprehensive Plan (BSP, 2018).

1. "Recognize the economic, health, cultural, and intrinsic values of nature, and the importance of community stewardship

2. Preserve natural resources and the beneficial functions and services they provide

3. Improve air quality and watershed health, including hydrology, water quality, fish and wildlife habitat, and biodiversity.

4. Ensure all Portlanders experience the benefits of a livable environment and healthy watersheds, and reduce environmental disparities affecting under-served and underrepresented communities.

5. Recognize the city's impact on global climate change, opportunities to reduce carbon emissions, and sequester carbon.

6. Recognize the importance of a healthy urban forest and natural systems in reducing the impacts of natural hazards, such as landslides, flooding, and wildfire, and in adapting to climate change.

7. Prevent incremental environmental degradation including the spread of invasive species, loss of habitat, and adverse impacts of additional impervious surfaces. 
8. Ensure that environmental protection programs and regulations reflect current data, the best available science, and evaluation of impacts to under-served and under-represented communities.

9. Advance good decisions and adaptive management through better data collection.

10. Ensure that plans and investments are coordinated with relevant policies from other City plans such as the Portland Watershed Management Plan, Urban Forest Management Plan, Climate Action Plan, Climate Change Preparation Strategy, Parks plans, Natural Hazard Mitigation Plan, and plans addressing environmental equity."

Source: pg. GP7-1, BSP (2018) 2035 Comprehensive Plan

Table 2: Climate Change Preparation 2030 Objectives from Climate Change Preparation Strategy: Risk and Vulnerabilities Assessment (City of Portland \& Multnomah County, 2014)

1. "Decrease the urban heat island effect, especially in areas with population most vulnerable to heat.

2. Minimize health issues caused by extreme heat days, especially for populations most vulnerable to heat.

3. Increase the resilience of Portland's water supply to drier summers.

4. Increase the resilience of natural systems to respond to increased temperatures and drier summers.

5. Manage the risk of wildfires as a result of drier summers.

6. Increase the resilience of natural and build environment to increased winter rainfall and associated flooding.

7. Manage the increased risk of disease due to changes in vector populations.

8. Manage the increased risk of landslides due to changing precipitation patterns.:

Source: pg. 6, City of Portland and Multnomah County (2014) Climate Change Preparation Strategy: Risk and Vulnerabilities Assessment. 


\begin{tabular}{|c|c|}
\hline & $\begin{array}{l}\text { Table 3: Goals of Conservation Activities from Greater Forest Park Conservation } \\
\text { Initiative (Myers et al, 2013). }\end{array}$ \\
\hline 1. & $\begin{array}{l}\text { "Streams: Protect and improve hydrologic processes and water quality in area streams, to } \\
\text { safeguard watershed functions and human health. }\end{array}$ \\
\hline 2. & $\begin{array}{l}\text { Connectivity: Protect and improve connectivity between Forest Park, the Tualatin Mountains, } \\
\text { the Coast Range, and the Willamette River. }\end{array}$ \\
\hline 3. & $\begin{array}{l}\text { Forests: Maintain and improve forests to support diversity, structural integrity, connectivity } \\
\text { and complexity. }\end{array}$ \\
\hline 4. & Wildlife: Maintain and protect native wildlife diversity." \\
\hline & $\begin{array}{l}\text { Information gathering and adaptive policy and planning that maintain the health of the } \\
\text { ecosystem and supports biodiversity. }\end{array}$ \\
\hline 6. & Acquisition of key habitat. \\
\hline 7. & Community education and outreach. \\
\hline
\end{tabular}

Source: pg. 8-10, Myers et al. (2013) Greater Forest Park Conservation Initiative.

Specific management actions included in the Forest Park UFSF were defined in the Forest Park Ecological Prescriptions document (PP\&R, 2011) and stakeholder workshops were used to prioritize the importance of these actions.

\section{Urban Forest Benefits Matrix for Forest Park}

An Urban Forest Benefits Matrix captures and displays the goals and actions that support a management and the co-benefits derived from each action. Figures 14 and 15 showcase the prioritized Goals and Actions for the Forest Park case study derived from management plans and stakeholder workshops. The two left-hand columns of the matrix display management actions that support the goals of the plan. Beneficial changes in ES functions and associated societal values resulting from management actions are displayed in the top row of the matrix. The changes in ecosystem services and associated benefits are derived from Urban Forest Causal Chains which are presented in the next section of this report. Generalized benefits from urban forests and those specific to Forest Park are organized by the three dimensions of sustainable development (environmental, social and economic) as shown in Figure 15 below. Checks marks in the Urban Forest Benefits Matrix indicate when a management action supports one or more of the benefits. 
Results of the Urban Forest Benefits Matrix provide a summary of benefits which may be ranked in relative value. It may be desirable to rank these values to prioritize actions. For example, the health benefits from recreation may be judged to have a higher value than carbon sequestration by stakeholders if chronic illness is of key concern to the region. Stakeholders may rank wildlife survival lower than carbon sequestration. By capturing co-benefits from an action in the matrix it becomes clear that actions that sequesters carbon also provides habitats for birds which attracts tourists to the area resulting in revenues for the hospitality industry. In this way, it can be seen at a glance which actions contribute to the triple bottom line of sustainable development.

\section{Urban Forest Benefits Matrix for Forest Park: Goals 1 and 2}

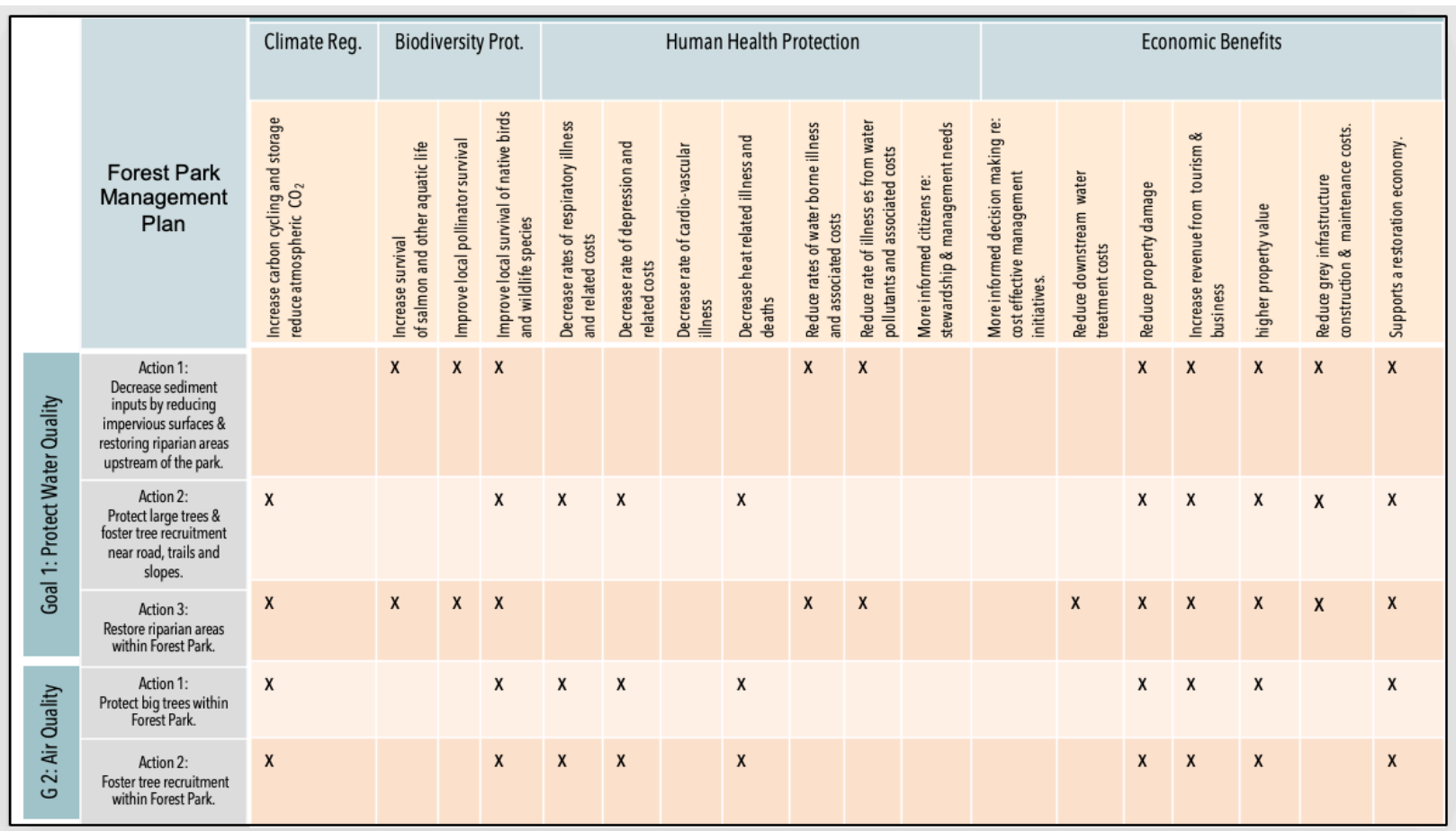

Figure 14.: This Urban Forest Benefits Matrix captures and displays Goals 1: Protect Water Quality, and Goal 2: Protect Air Quality and the prioritized management actions in a Forest Park Management Plan. Beneficial changes in ES functions and associated societal values are displayed in the top row of the matrix which are derived from development of causal chains. The changes in ES function and associated benefits are organized by environmental, societal and economic benefits, the three pillars of sustainable development. Check marks indicate which benefits each action provides 


\section{Urban Forest Benefits Matrix for Forest Park: Goals 3 and 4}

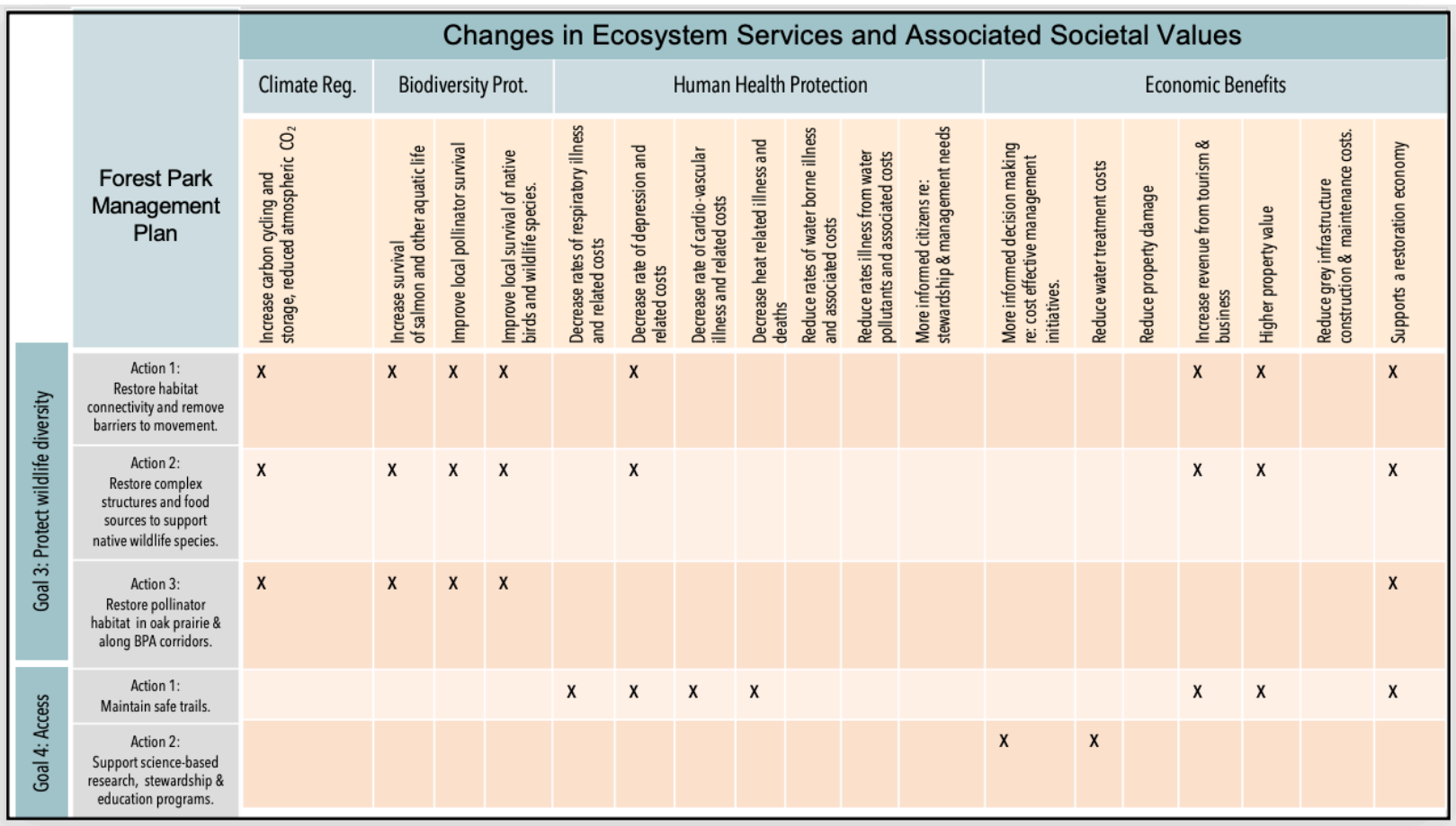

Figure 15: This Urban Forest Benefits Matrix captures and displays Goals 3: Protect Wildlife Diversity, and Goal 4: Provide Access and the prioritized management actions that support these goals in a prioritized Forest Park Management Plan. Beneficial changes in ES functions and associated societal values are displayed in the top row of the matrix which are derived from development of causal chains. The changes in ES function and associated benefits are organized by environmental, societal and economic benefits, the three pillars of sustainable development. Check marks indicate which benefits an action provides.

\begin{tabular}{|c|c|c|}
\hline $\begin{array}{l}\text { Climate Regulation \& } \\
\text { Biodiversity Protection } \\
\text { (Environmental } \\
\text { Sustainability) }\end{array}$ & $\begin{array}{l}\text { Human Health Protection } \\
\text { (Social Sustainability) }\end{array}$ & $\begin{array}{l}\text { Economic Benefit } \\
\text { (Economic Sustainability) }\end{array}$ \\
\hline $\begin{array}{l}\text { Carbon sequestration and storage: } \\
\text { reduced atmospheric } \mathrm{CO}_{2}\end{array}$ & $\begin{array}{l}\text { Decrease rates of respiratory } \\
\text { illness and related costs }\end{array}$ & $\begin{array}{l}\text { More informed decision making } \\
\text { re; cost effectiveness of } \\
\text { management initiatives }\end{array}$ \\
\hline $\begin{array}{l}\text { Increased survival of salmon and } \\
\text { other aquatic life }\end{array}$ & $\begin{array}{l}\text { Decrease rates of depression and } \\
\text { related costs }\end{array}$ & $\begin{array}{l}\text { Reduce downstream water } \\
\text { treatment costs }\end{array}$ \\
\hline Improve local pollinator survival & $\begin{array}{l}\text { Decrease rates of cardio-vascular } \\
\text { disease and related costs }\end{array}$ & Reduce property damage \\
\hline \multirow[t]{4}{*}{$\begin{array}{l}\text { Improve survival of local native } \\
\text { bird and wildlife species }\end{array}$} & $\begin{array}{l}\text { Decrease heat related illness, } \\
\text { costs, and deaths }\end{array}$ & $\begin{array}{l}\text { Increase revenues from tourism } \\
\text { and business }\end{array}$ \\
\hline & $\begin{array}{l}\text { Reduce water borne illness and } \\
\text { associated costs }\end{array}$ & Increase or protect property value \\
\hline & $\begin{array}{l}\text { Reduce illness and costs from } \\
\text { water pollutants }\end{array}$ & $\begin{array}{l}\text { Reduce grey infrastructure } \\
\text { construction and maintenance } \\
\text { costs }\end{array}$ \\
\hline & $\begin{array}{l}\text { Increase number of citizens } \\
\text { informed of the value of } \\
\text { ecosystem stewardship and } \\
\text { management investments }\end{array}$ & $\begin{array}{l}\text { Supports a restoration economy } \\
\text { including jobs and production ofc } \\
\text { climate appropriate nursery stock. }\end{array}$ \\
\hline
\end{tabular}

Figure 16. Benefits from ecosystem services are categorized by three pillars of sustainable development: Environmental Sustainability in the form of Climate Regulation and Biodiversity Protection, Societal Sustainability in the form of Human Health Protection, and Economic Sustainability in the form of Economic Benefits. These benefits are listed in the top row of the Urban Forest Benefits Matrix. 


\section{Urban Forest Causal Chains for Forest Park}

Urban Forest Causal Chains form the foundation of the Urban Forest Services Framework (UFSF).

Leveraging Olander's Benefit Relevant Indicator (BRI) methodology (Olander et al., 2018), the UFSF causal chains provide a mechanism to translate an ES into a measurable outcome directly related to human welfare (Olander et al. 2018). BRIs is particularly useful when establishing non-use or intrinsic values of ecosystem services. They are flexible in that they provide a method to capture the societal issues most important to stakeholders and, using causal chains tie them to management actions that help achieve the desired benefits (Olander et al, 2018). These chains map a management action that improves or stabilizes an ecosystem function resulting in a benefit or BRI(s) is expressed in terms of a desired and measurable change in ecosystem service resulting in a change in societal value. The UFSF includes a Risk Relevant Indicator (RRI) to capture the perceived or real risks and costs associated with the management action (Hardy et al. in preparation 2020). The resulting chains visualize costs versus benefits of management actions, and capture concepts for risk mitigation strategies during stakeholder workshops. The values associated with BRIs and RRIs may not all be expressed in the same form of currency or may not be represented in any form of currency, such as the perceived beauty of a coniferous forest. Input from the stakeholders is recommended to assign perceived or actual values.

The process of developing Urban Forest Causal Chains provides the opportunity to build a shared understanding among stakeholders of the documented benefits derived from ecosystem services, and gain buy-in from diverse stakeholders on the direct and measurable values associated with management actions to support urban forest health and access. The practice of developing these causal chains teaches people to think in terms of ecosystem functions and translates changes in functions to measurable benefits from those services. To gain support for funding for management, it is vital that stakeholders buy-in to the concept that novel urban forest ecosystems, such as Forest park, require aggressive active management to protect ecosystem services from declining. The aim of the developing causal chains is, in part, to illustrate this point. If stakeholders desire specific outcomes derived from the protection of urban forests, sources of funding must be secured to fund the actions. Potential funding sources are identified later in this report and are based on the resources needed to manage urban forests for resilience.

The following nine examples of causal chains are specific to the Forest Park case study. I emphasize that these actions are focused on improving ecosystem function. Without these actions, the assumption is 
that the ecosystem function will continue to decline over time. For Forest Park, evidence that shows a decline in services is documented in the Findings Q1 section of this report.

\section{Protect Water Quality}

In support of the goal to protect water quality, causal chains focus on the benefits associated with water filtration and water regulation from urban forests. Desired outcomes are expressed in several terms including measurable benefits using Oregon's Department of Environmental Quality's (DEQ) Total Daily Maximum Load (TMDL) regulatory requirements as a target for turbidity, pollutants, E. Coli, and cyanobacteria in the tributaries and the mainstem of the Willamette. The resulting changes in societal values include decreased cost of illness from toxic pollutants, reduced cost of flood damage, reduced rate of illness from cyanobacteria and E. Coli, and improved salmonid survival rates. Each of these values could potentially be translated to monetary terms if practical or desirable. I maintain that the concept of this framework is to showcase the societal values associated with ecosystem services and identify the actions need to improve or stop the decline of ecosystem functions thereby defending the need to provide resources to achieve the action. If stakeholders desire these outcomes, sources of funding must be identified even if there is no revenue that directly offset the costs. Recommendations for funding can be found later in this report.

Every four years, Portland's Bureau of Environmental Services (BES) conducts an assessment of Portland's rivers, streams and watersheds and summarizes the conditions in the form of a report card for water quality, hydrology/flow of water, habitat environment, and health of fish and wildlife (BES, 2019). According to the BES 2019 Watershed Health Index, the Willamette River tributaries receive a D+ for hydrology due to streets and other hard surfaces that create stormwater runoff and streams flow through underground pipes. On a scale from 1(F) -10(A), 10 being good and 1 poor, the Willamette tributaries scores a 3.9 for effective impervious area, and 3.3 for stream connectivity. Water quality receives a B- for stormwater pollutants with high levels of dissolved copper (score of 5.1), phosphorous (6.3) and mercury (1.0), temperature (4.5), total suspended solids (4.7) (BES, n.d.-a). BES scores for habitat health B vegetation next to streams which is good in many parts. BES notes invasive plants threaten the forests in near the Upper Willamette tributaries, even though tree canopy is rated 10 based on the high percentage of tree coverage near Forest Park. Stream accessibility is poor (1.0) because of number of piped streams and fish access is blocked between the Willamette River and Forest Park's streams (BES, n.d.-a). 
Goal 1/Action 1 Causal Chain (Figure 17) maps the action: reduce sediment inputs in area adjacent to Forest Park through land-owner education, purchase of easements and incentives to the desired change in ecosystem function to the ES Function: increase water filtration upstream to improve water clarify in Forest Park streams and the Willamette River as illustrated in Figure 16. Resulting desired change in ecosystem functios are 1) improve survival of salmonid species and other aquatic life, 2) reduce exposure to cyanobacteria, and 3) reduce sediments blocking flood drains to reduce damage from flooding. Reducing impacts from toxins in urban storm water and sediment runoff can improve juvenile salmonid survival rates (McIntyre et al. 2015) and reduce water borne illness rates (Berland et al. 2017) both societal benefits. RRIs are focused on interference with development and costs are identified as landowner education, incentives and easement purchases of lands outside Forest Park.

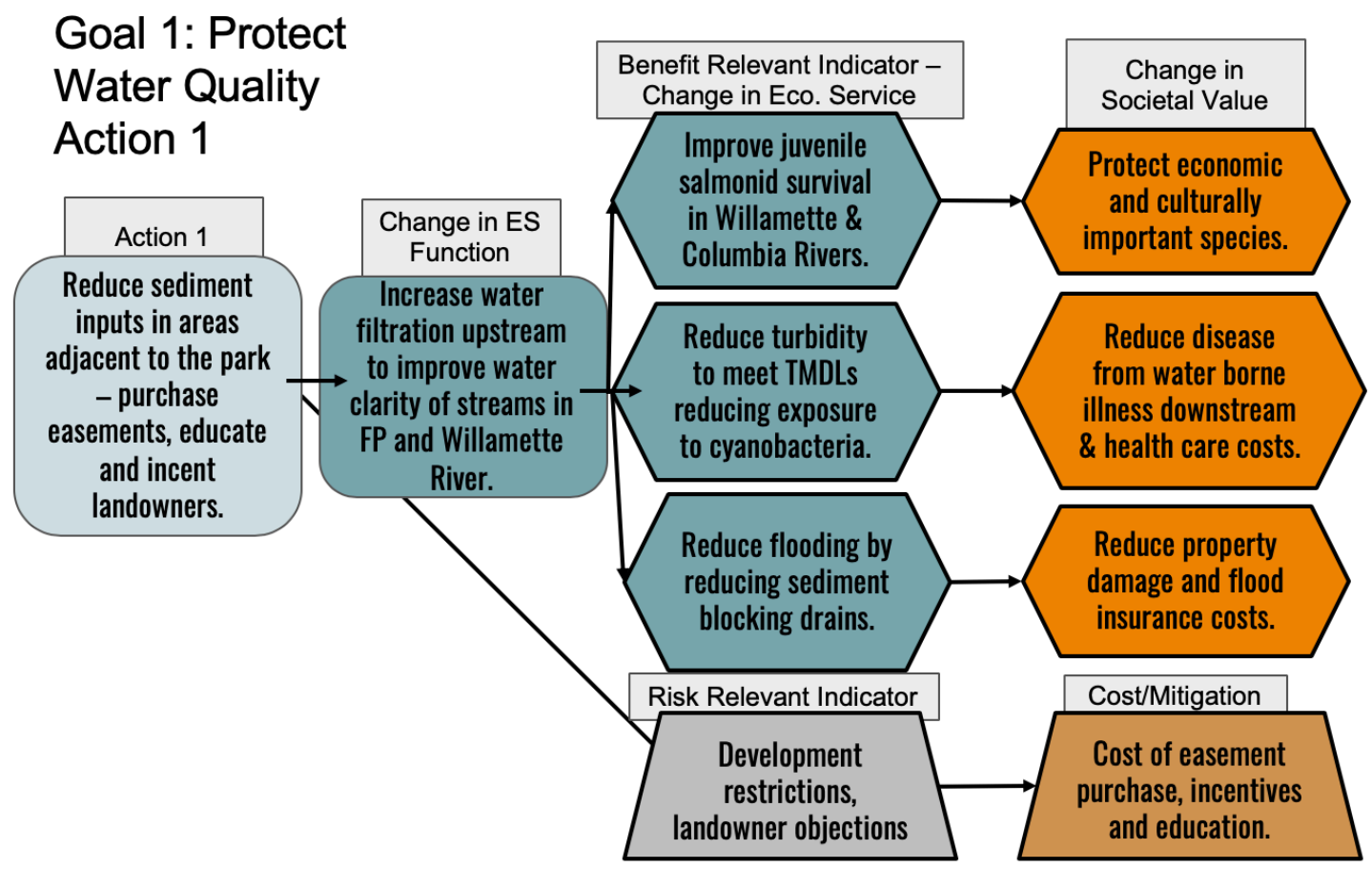

Figure 17. This Casual chain maps the action of reducing sediment inputs in areas adjacent to the park to the desired changes in ecosystem function of increasing water filtration with the benefits of 1) increasing salmon survival protecting this economic and culturally important species,2) reducing turbidity to meet DEQ'S TMDLs to reduce exposure to cyanobacteria reducing illness and associated costs, and 3) to reduce flooding by reducing sediment blocking storm drains thereby reducing property damage and potentially insurance costs. Risk Relevant Indicators (RRIS) include potential restrictions to development and resistance of landowners. Associated costs are land-owner education, incentives and purchase of easements.

Goal 1/Action2 Causal Chain (Figure 18) maps the action: protect large trees and foster tree regeneration in areas adjacent to roads, trails and streams to an in ES function: increase water absorption and storage 
and provision of shade resulting in 1) improved ecosystem services to decrease flooding, 2) decrease runoff of toxins and 3)increase salmonid survival as illustrated in Figure 18. Benefits are similar to those from Action 1 but occur in a different geographic region, i.e. within the park and adjacent to streets, trails and streams. This action protects trees which has co-benefits evidenced in the causal chains focused on improving air quality. RRIs are focused on potential damage from falling trees and limbs and associated costs for management.

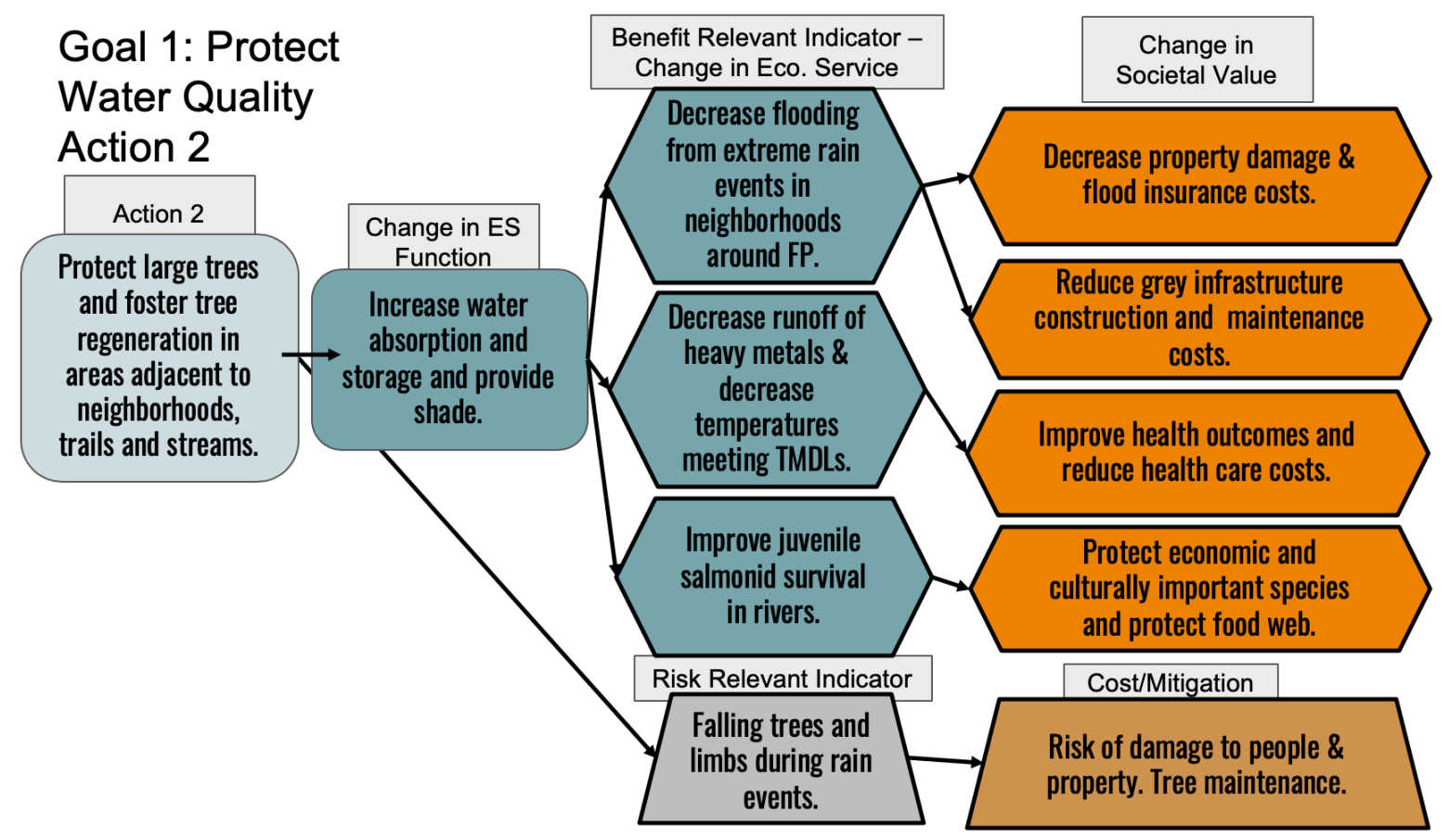

Figure 18. This causal chains maps the action of protecting large trees and fostering tree regeneration in areas adjacent to neighborhoods, trails and streams to improve water filtration and storage resulting in 1) decrease flooding events reducing property damage and flood insurance costs and reducing the construction and maintenance cost of grey infrastructure 2) decreasing metals and temperatures in streams to meet TMDLs improving health outcomes and reducing health care costs, and 3) improve salmon and other aquatic life survival protecting culturally and economically important species and protecting the food web. Risks include injury and property damage from falling trees and limb.

Goal 1/Action 3 Causal Chain (Figure 19) maps the action: restore riparian areas within and upstream of Forest Park by removing invasive plants and replanting native plants and trees which stabilize the stream bank and provide shade with the benefits of 1) increasing salmonid and other aquatic life survival rates protecting important species and the food web, 2) reducing turbidity to meet TMDLs reducing cyanobacteria and the risk of illness and related costs, and 3) reducing the levels of E. Coli in the streams 
by blocking access by dogs and humans improving health outcomes downstream. RRIs are associated with the challenges faced by restricting access to streams and the potential need to provide toilet facilities.

\section{Goal 1: Protect Water Quality Action 3}

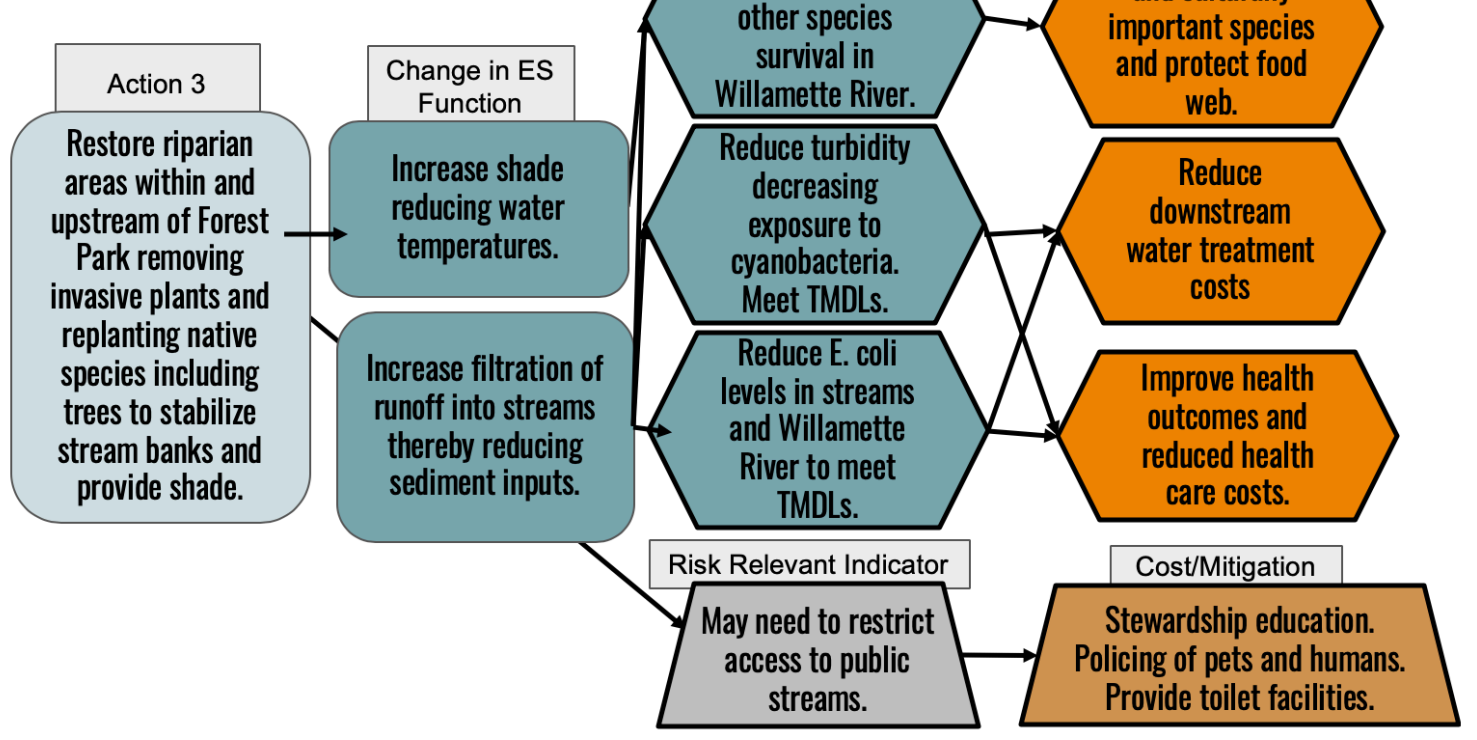

Figure 19 This causal chains maps the action of restoring riparian areas within and upstream of Forest Park by removing invasive plants and replanting native plants and trees which stabilize the stream bank and provide shade with the benefits of 1) improving salmonid and other aquatic life survival protecting important species and the food web, 2) reducing turbidity to meet TMDLs reducing cyanobacteria and the risk of illness and related costs, and 3) reducing the levels of E. Coli in the streams by blocking access by dogs and humans improving health outcomes downstream. RRIs are associated with the challenges faced by restricting access to streams and the potential need to provide toilet facilities.

\section{Protect Air Quality}

The management actions associated with these causal chains focus on actions that protect air quality. The UFSF reveals the multiple co-benefits result from actions that protect big trees and foster tree regeneration in urban forests.

Emissions of air pollutants such as sulfur and nitrogen oxides and particulates have health impacts as well as effects on ecosystems (Rao et al., 2017). These emissions can change atmospheric chemistry impacting global and regional climate (Rao et al., 2017). In recent years air toxics have been a focus of concern in the Portland region. Air toxics are generally defined as air pollutants known or suspected to cause cancer 
or other serious health problems. Air toxics include diesel soot, benzene, polycyclic aromatic hydrocarbons (tar-like by-products from auto exhaust and other sources), and metals including manganese, nickel, and lead. Air toxics come from a variety of sources including cars and trucks, all types of burning (including fireplaces and woodstoves), businesses, and consumer products such as paints. There are no federal standards for air toxics (DEQ, n.d.-a). Many studies have documented that trees provide air filtration and higher percentages of tree canopy are associated with reduced rates of respiratory illness (Elmqvist et al., 2015; Escobedo et al., 2009, 2011; Nowak et al., 2018; Rao et al., 2014).

Trees act a sink for $\mathrm{CO}_{2}$ by fixing carbon during the photosynthesis process and storing carbon as biomass. $\mathrm{CO}_{2}$ storage changes over time as trees grow and decay. Several studies show that large trees sequester more carbon than smaller trees and by protecting them, potentially we slow the accumulation of atmospheric CO2 mitigating climate change (Nowak \& Green, 2002, Rao et al., 2018, Turner-Skoff \& Cavender, 2018). The amount of carbon stored can be estimated using tools such as i-Tree which requires an inventory of trees of be conducted and is commonly used by urban planners.

Multiple studies reveal that shade from urban trees reduces heat related illness and mortality rates (Hardin et al, 2007, Kravchenko et al, 2013, Shandas et al, 2019). Green views including those of urban forests reduce rates of stress and depression by buffering noise among other functions (Dravta et al, 2010; Gilof-Gunnarson \& Ohstrom, 2007; Turner-Skoff \& Cavender, 2019). Portland's Terrestrial Ecology Enhancement Strategy (TEES) (BES, 2017) and the Forest Park Wildlife Report (PP\&R, 2010) identify bird, other vertebrate and invertebrate species associated with habitats provided by large old coniferous trees with multi-layer tree shade-tolerant and large diameter trees such as those found in many areas of Forest park. Special status birds species associated with these forest types include: band-tailed pigeon, pileated woodpecker, olive-sided flycatcher, Hammond's flycatcher, Pacific-slope flycatcher, brown creeper, winter wren, Swainson's thrush, varied thrush, black- throated gray warbler, hermit warbler, Wilson's warbler, red crossbill (BES, 2017).

Goal 2/Action 1 Causal Chain (Figure 20) maps the action of protecting big trees throughout Forest Park to increased air filtration and carbon storage and sequestration resulting in 1) reducing NOx thereby rates of respiratory illness and associated costs, 2) reducing atmospheric CO2 mitigating climate change, and 3) providing habitats for special status bird and animal species for viewing and study. For a park the size of 
Forest Park, mapping and monitoring big trees will require partnership with research institution that can provide the tools and expertise to perform these functions,

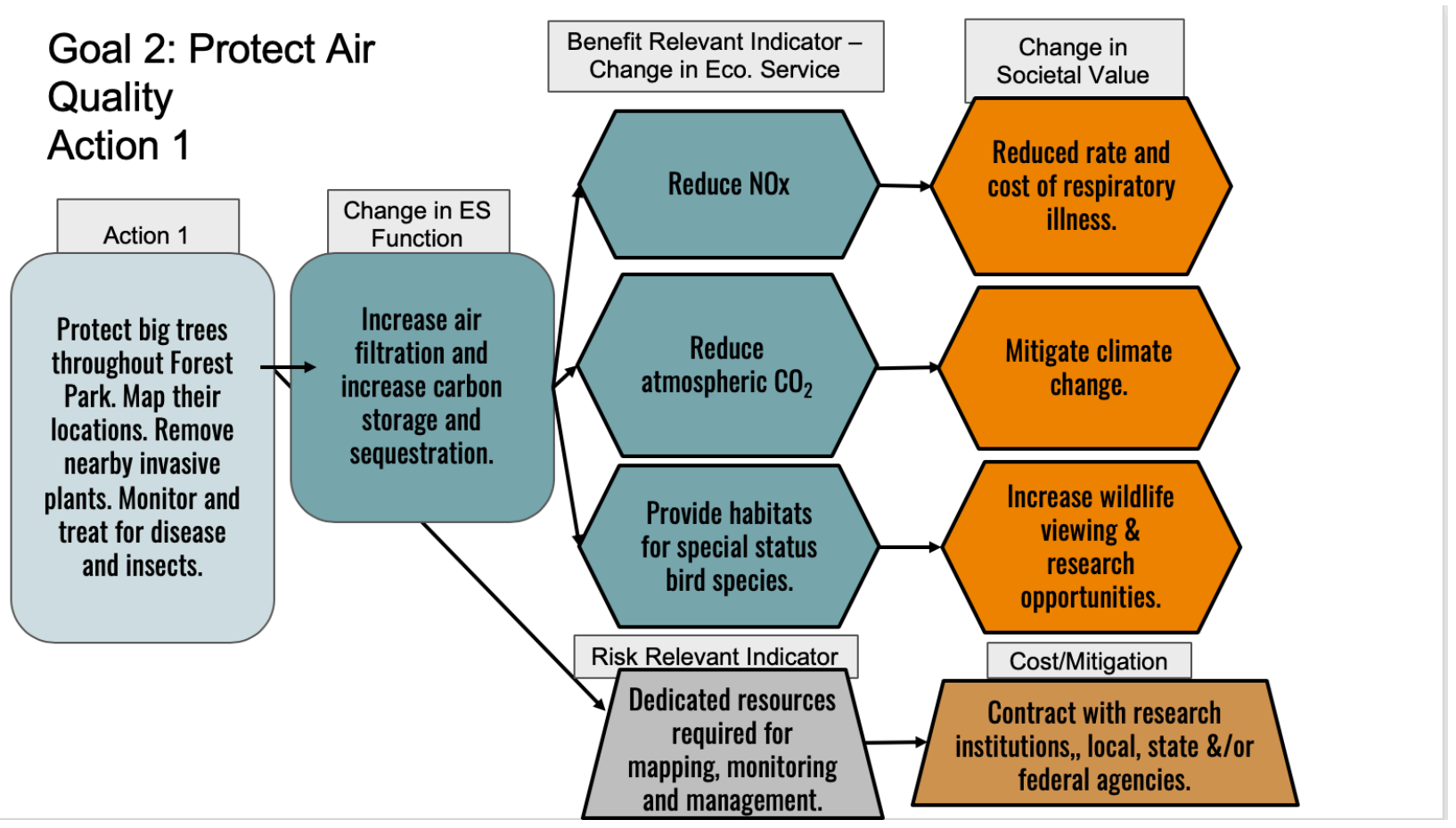

Figure 20. This causal chains maps the action of protecting big trees within Forest Park resulting in increased air filtration and carbon storage resulting in three benefits 1) reduced NOx thereby reducing rates and costs and respiratory illness, 2) reducing atmospheric $\mathrm{CO} 2$ mitigating climate change, and 3) providing habitats for special status bird species increasing the opportunity for wildlife viewing and study. The risk and cost of undertaking this effort is that it requires specialized tools and skills and ma require contracting with research institutions or state or federal agencies.

Goal 2/Action 2 Causal Chain (Figure 21) maps the action of fostering tree regeneration by adding woody debris, and planting and protecting seedlings where natural recruitment is not occurring to increase air filtration, carbon storage and increased nutrient cycling. Targeted benefits include 1) reduce NOx thereby reducing rates of respiratory illness and associated costs, 2) reduce atmospheric $\mathrm{CO}_{2}$ mitigating climate change, and 3) improve soil conditions to foster a resilient self-regenerating forested ecosystem for future generations. This action, too, requires mapping and monitoring services and tools that may best be provided through service agreements with research institutions or state and federal agencies who possess the specialized skills and tools. 


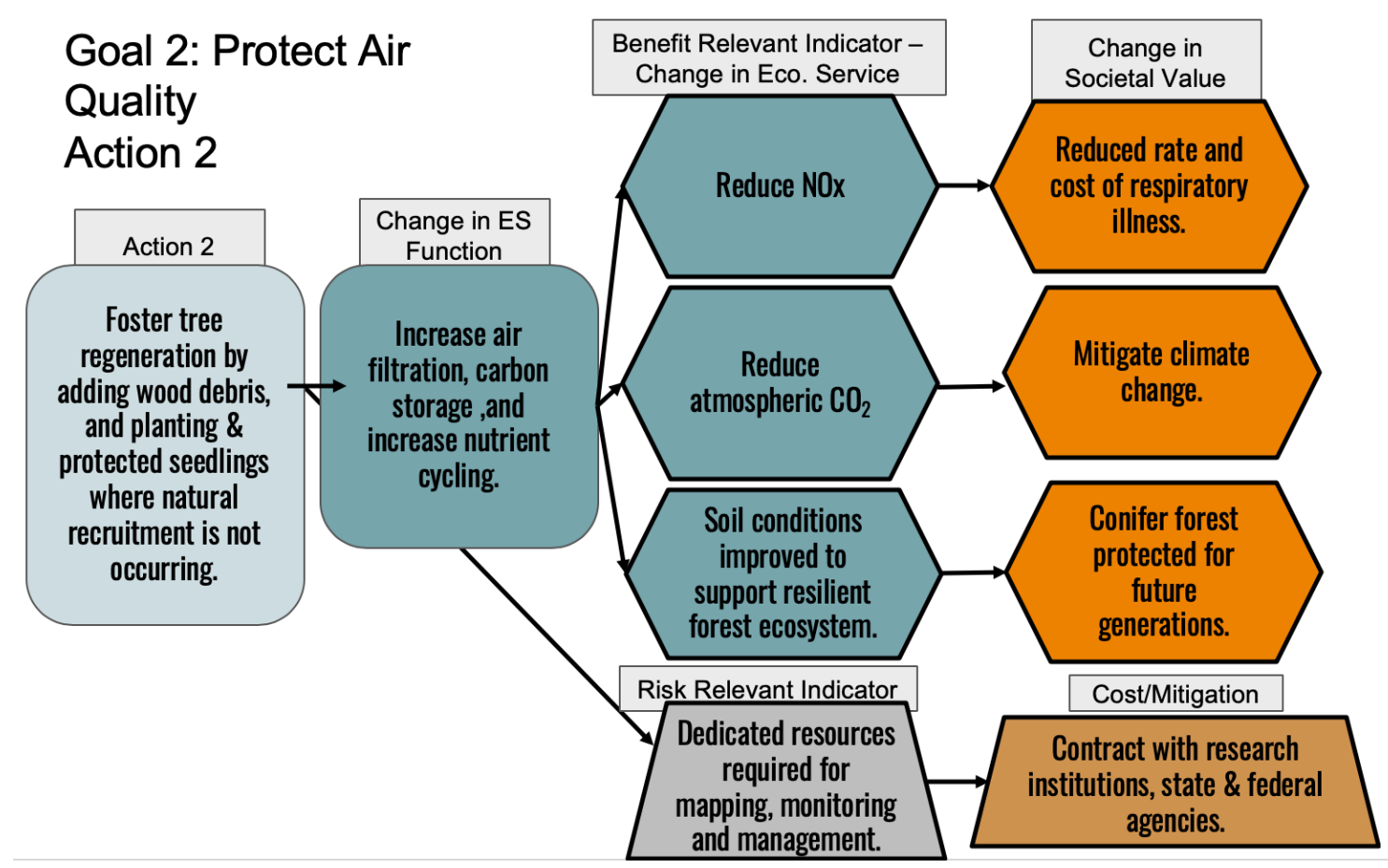

Figure 21. This causal chains maps the action of fostering tree regeneration by adding woody debris and protecting seedlings where recruitment is not occurring perpetuating the forest cycle providing the benefits of 1) reducing NOx thereby reducing the rate of respiratory illness and related costs, 2) reducing atmospheric $\mathrm{CO} 2$ mitigating climate change, and 3) improved soil conditions to support resilient and self-regenerating forest for future generations. The risk and cost of undertaking this effort is that it requires specialized tools and skills and ma require contracting with research institutions or state or federal agencies.

\section{Protect Wildlife}

The BES scorecard gives Fish and wildlife in the area adjacent to the Upper Willamette tributaries a D+. Cut-throat trout live in streams in Forest Park, but barriers block fish passage (score; 1.2). A high level of tree canopy provides habitat for birds more than 104 species identified (Score for birds: 4.8), macroinvertebrates 5.6 (BES, n.d.-a).

Management actions that reduce barriers to vertebrate animal movement supports carbon cycling helping to mitigate climate change. Animals preying on other animals or eating fruit results in accumulation of organic material on and in the group which increases soil microbes which convert remains into stored carbon (Kubota 2017) which helps mitigate climate change. Barrier removal provides migration pathways for animals who may need to shift their range because of climate change and provides functional food webs and nutrient cycling (Mitchell et al. 2013, 2015, MEA 2005, Butler et al. in preparation 2020). Multiple studies connect increased wildlife viewing in cities to reduced rates of depression (Clark et al. 2014, Shanahan et al. 2016). Shanahan reports a 9\% reduction in depression with 
30 minutes of access to nature per week. Depression is predicted to be the leading cause of disease burden (a measure of mortality and disability) by 2030, particularly in urban areas (WHO 2011). When the cost of depression is extrapolated to Portland, the value of reducing health care costs associated with depression by $9 \%$ could be as high as $\$ 62.3$ million/year. This value is significant and deserves further evaluation to determine if there is a way to directly attribute values to Forest Park.

The risks and costs associated with removing barriers include the cost of land acquisition and restoration, the risk of undesirable species in the city, and risk of animal and plant pathogen vectors. These risks and costs could be mitigated by collaboration with landowners and by educating the general public as to the value of protecting both native and remnant habitats. Risks associated with restoration of habitats include lack of training of volunteers and contractors who could inadvertently disturb habitats. The impact of trampling associated with hand pulling ivy, and the application of herbicides to kills invasive plants has not been studied. Multiple studies note these risks (Broshot, 2009, Dresner et al. 2018, Hardy et al. unpublished paper 2018).

Goal 3/Action 1 Causal Chain (Figure 22) maps the action of removing physical barriers to animal movement and reconnecting fragmented habitats between Forest Park, the Tualatin Mountains, the Coast Range the Willamette River and the Columbia River Gorge by restoring migration paths, supporting functional food webs, and increasing carbon and nutrient cycling in these areas. Resulting desired benefits include 1) increase carbon burial mitigating climate change, 2) increase survival rates of migrating birds and animal species for future generations, and 3) increasing views of valued wildlife species which is associated with decreased rates of depression and serves to attract tourists and businesses to Portland. The risks and costs are undesirable species in the city and interference with development and transportation systems requiring investments in land-owner incentives, easements, education, and collaboration in urban development and transportation system design. 


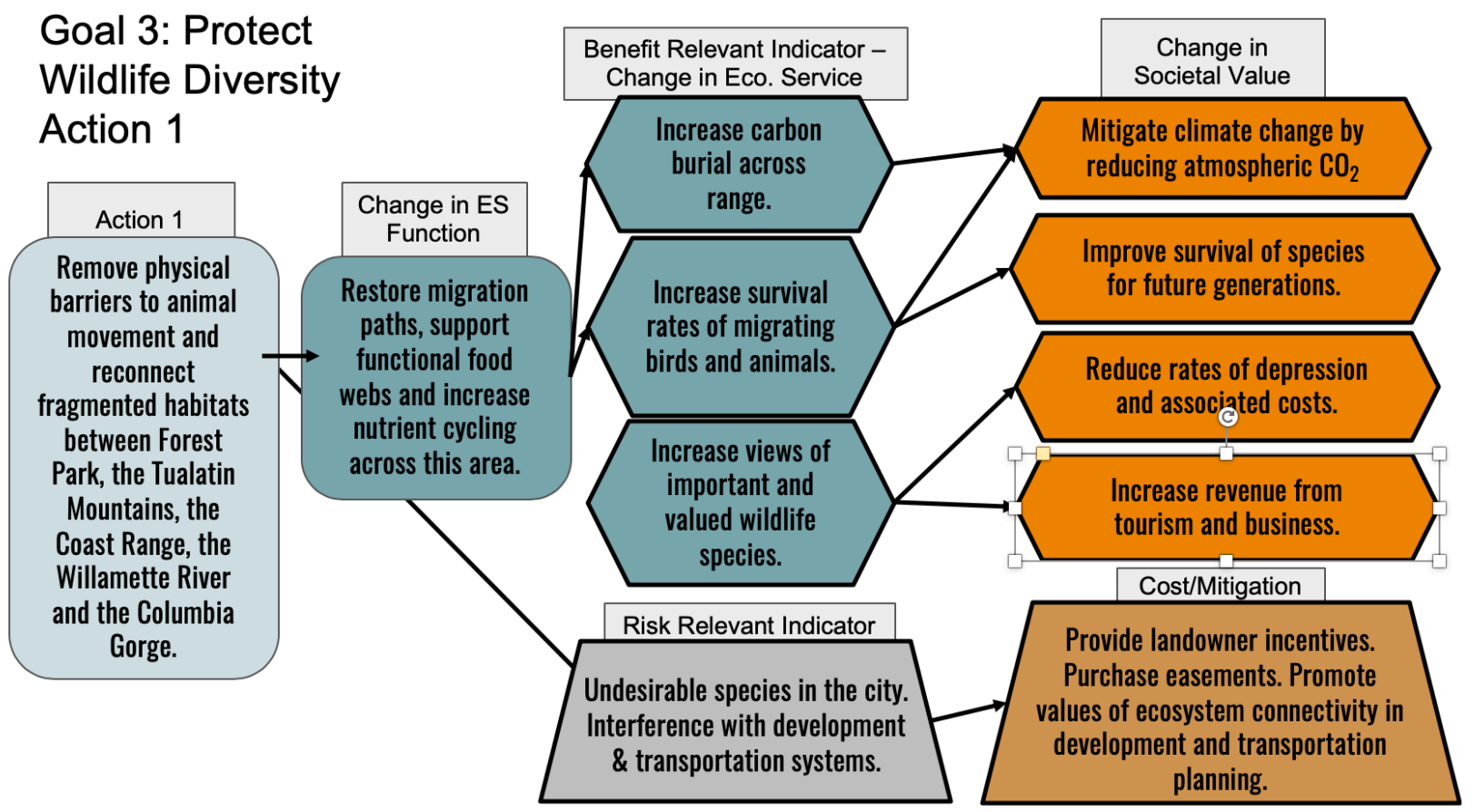

Figure 22. This causal chain maps the action of removing physical barriers to animal movement and reconnecting fragmented habitats to restore migration paths, support a functional food web and increase nutrient and carbon cycling resulting in multiple benefits. 1) Increased carbon burial mitigating climate change, 2) increased survival rates of birds and animals that need to shift their range improve survival of species for future generations, 3) providing views of valued wildlife which has been linked to decreased rates of depression and 4) increasing revenue from tourism and businesses. Risks and costs are associated with undesirable species in the city and interference with development and transportation systems requiring investments in incentives, easements, education and requires collaboration in design of development and transportation system planning.

Goal 3/Action 2 Causal Chain(Figure 23) maps the action of removing invasive species and restoring vegetation to provide complex structures and food sources for native wildlife prioritizing areas of greatest risk of degradation and/or areas that disrupt habitat connectivity increasing the provision of structures and food sources to support diverse wildlife species. Multiple desired benefits may result: 1) increase the populations of important and valued bird species increasing opportunities for wildlife viewing which among other benefits attracts tourists to the area providing revenue to the city, 2) increase populations of native pollinators which protects economically and culturally important crops and 3) increase populations of valued reptiles and mammals which protect the food web protecting biodiversity for future generations. Current restoration efforts being conducted in Balch Creek and other areas of the park use volunteers and contractors who must be trained to avoid disruption of habitats, and as yet there is unknown impact of herbicides used to treat the invasive plant species requiring research and monitoring of restoration efforts. 


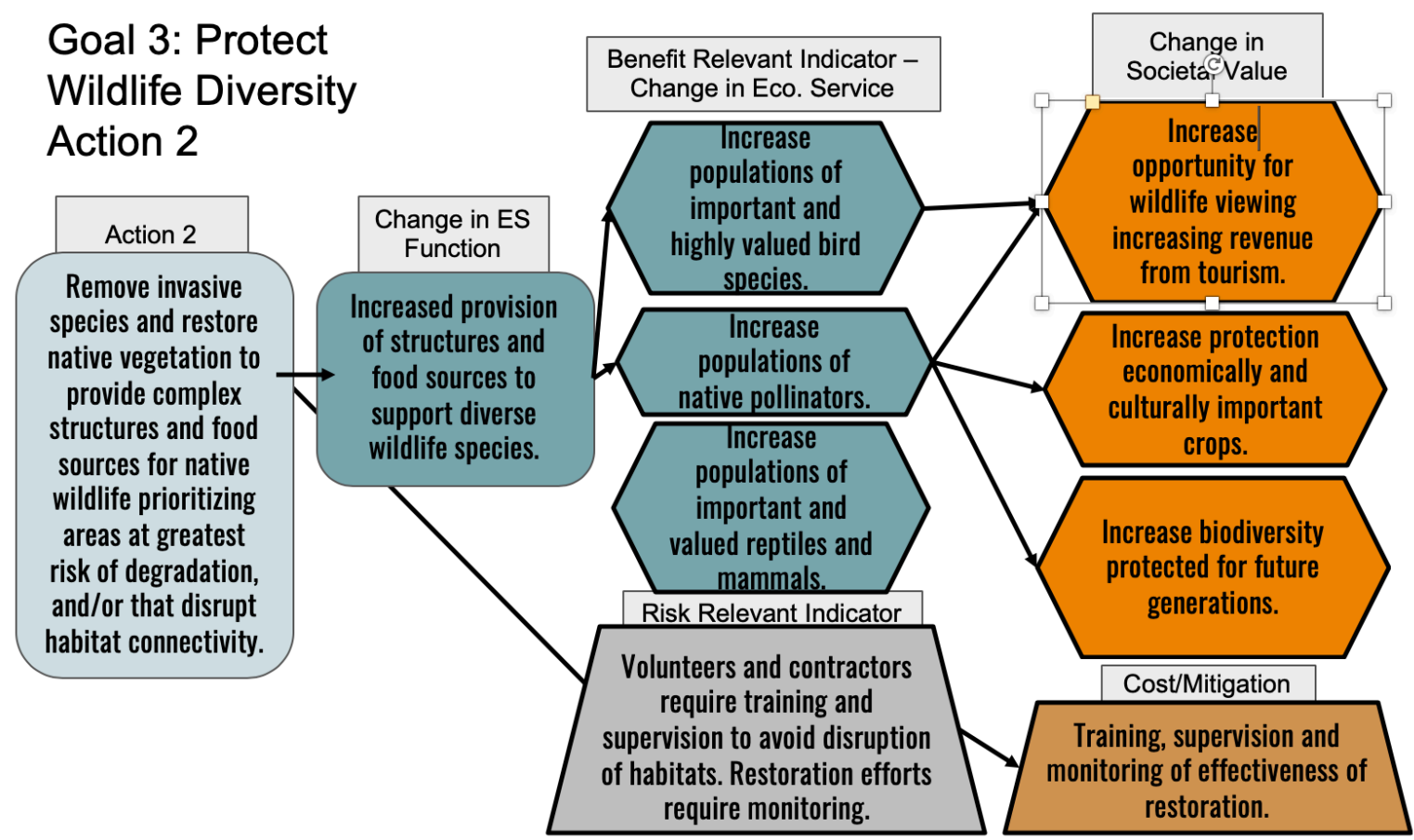

Figure 23. This causal chain maps the action removing invasive species and restoring native vegetation to provide complex structures for wildlife by increasing the provision of structures and food sources resulting in the benefits of 1) increasing local populations of important and valued bird species increasing opportunities for viewing thereby increasing revenues for tourism, 2) increasing populations of native pollinators protecting economically and culturally important crops, and 3) increasing populations of important and valued reptiles and mammals protecting biodiversity for future generations. Restoration efforts currently employee volunteers who must be trained to avoid disruption to ecosystems. Adequate investments in resources are needed to fund operations.

\section{Provide Access to Nature}

Urbanization creates common health risks to its citizens from air pollution, physical inactivity and stress resulting in obesity, cardiovascular and pulmonary disease, health related strokes and illnesses and increased stress (WHO, 2012). In Portland, some of the highest health risks are obesity, diabetes, high blood pressure and depression (Center for Disease Control, 2015). Based on Rosenberger \& Dunn's Outdoor Recreation Metrics study conducted through Oregon State University (OSU, the risk of these and other chronic diseases can be reduced by regular exercise (Rosenberger \& Dunn 2018). In general, Rosenberger's statements are supported by public health professionals (van den Bosch et al. 2018). Any amount of sustained physical activity results in health benefits, and greater amounts of activity are correlated with additional health benefits. The greatest marginal health benefits are derived by inactive people becoming active. Increasing Oregon's physical health may help reduced the estimated \$39.1 billion spent by Oregonians on health care annually (Rosenberger \& Dunn 2018). These estimates are 
conservative and underestimate the health benefits derived from physical activity because they don't include impact on all diseases including avoided deaths, productivity and other values. The cost savings accrue to health insurers, providers, and participants (Rosenberger \& Dunn 2018, van der Bosch et al, 2018).

The model developed by Rosenberger \& Dunn is called the Integrated Transport and Health Impact Model (ITHIM). "ITHIM is a comprehensive health impact assessment model that uses comparative risk assessment to quantify the estimated change in life expectancy and quality of life for a population due to changes in active transportation participation. ITHIM's physical activity pathway estimates health effects based on quantified relationships (dose-response functions) between physical activity (i.e., walking and cycling active transportation) and chronic illnesses, such as cardiovascular disease, diabetes, and some cancers. These estimated health effects are then converted into monetary units via Cost of Illness (COI) savings meta-analysis function. These COI estimates include disease-specific direct treatment costs and lost productivity costs" (Page 3, Rosenberger \& Dunn, 2018).

Using the Nature to Health model developed in 2018 (Hardy unpublished paper 2018), values from the Rosenberger \& Dunn study (Rosenberger \& Dunn, 2018), are incorporated to quantify the annual value of recreation from Forest Park based on the types of activities reported by visitors (PP\&R \& PSU 2012) as shown in Figure 24. A range of values results. Savings from avoided cost of illness range from 1) jogging on trails ranges from $\$ 28$ - \$507 per person, 2) walking on trails from $\$ 78-\$ 594$ per person, and 3) cycling on trails from $\$ 56$ - $\$ 650$ per person for a total of $\$ 28$ - $\$ 650$ per person per year. 


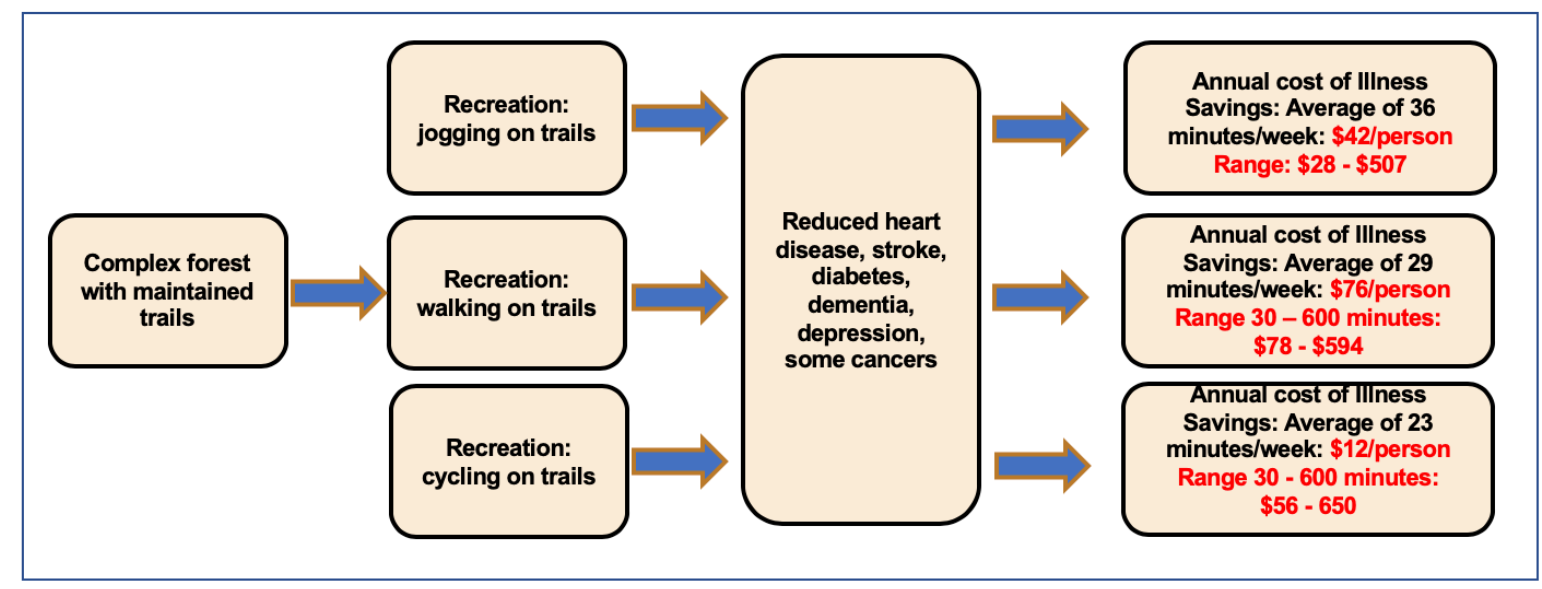

Figure 24. Forest Park Recreation Calculator Provides a range of values from various recreation activities on forested trails using data from the Rosenberger \& Dunn study and reports of recreation activity obtained from the Forest Park Recreation study conducted by PSU for PP\&R.

In addition to providing health benefits, access to nature provides co-benefits including the economic benefits of attracting tourism and businesses to Portland. Risks associated with providing unlimited access are the negative impacts on ecosystem functions. Limiting access would be difficult even if it were desirable. Promoting stewardship through educational programs and events, volunteer programs, citizen science projects and marketing could help protect the environment and also encourage financial support for management of urban forests through taxes, sponsorships, donations or fees.

Goal 4/Action 1 Causal Chain (Figure 25) maps the action of physically maintaining safe trails to meet the demand of hikers, bikers and horseback riders while protecting ecosystem functions increases access to nature and the aesthetic beauty of the park resulting in multiple benefits including wildlife viewing which attracts tourists and businesses to Portland, provides access to recreation with many health benefits as detailed above, but requires supervision and education to protect ecological functions. 


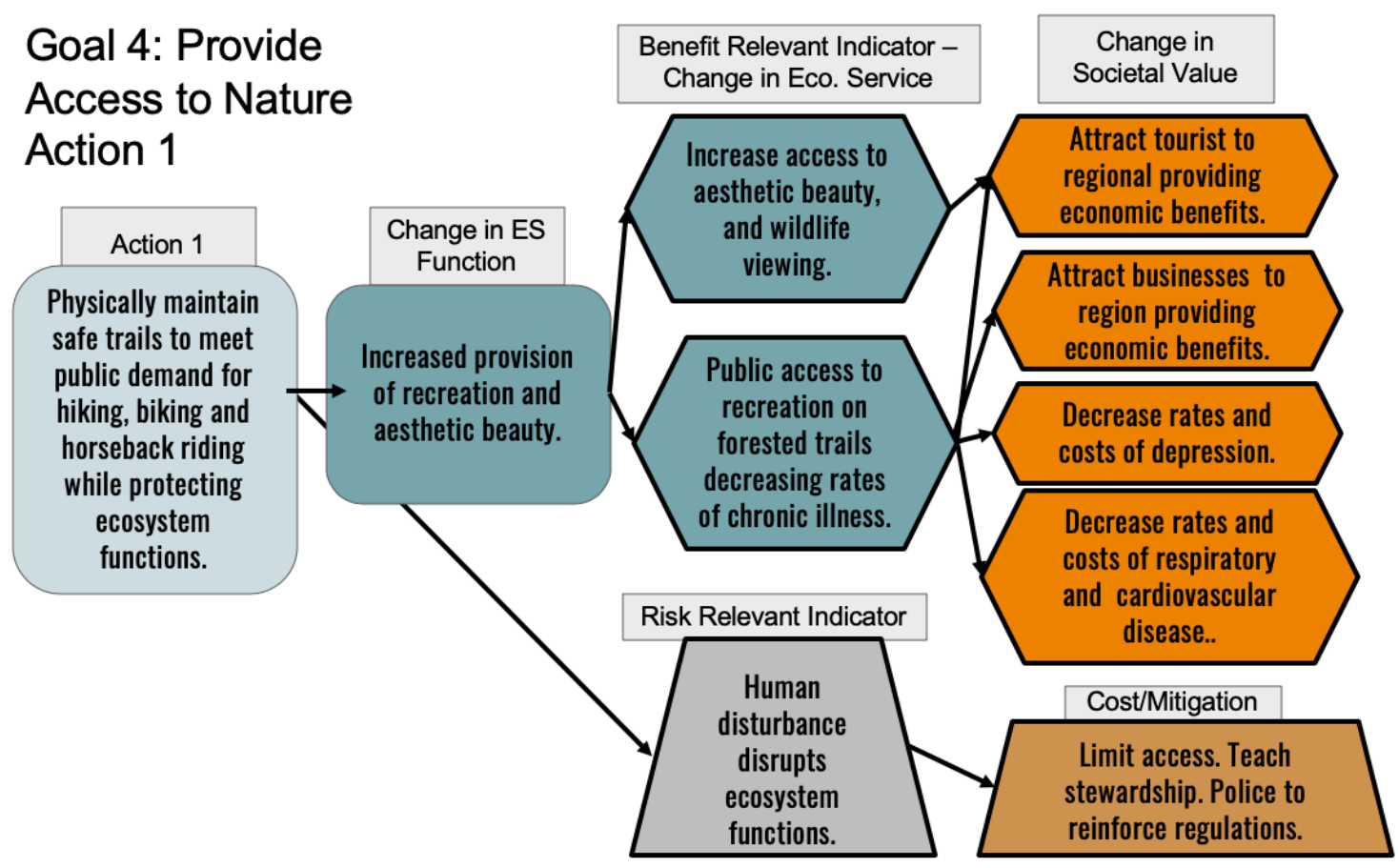

Figure 25 maps the action of physically maintaining safe trails to meet the demand of hikers, bikers and horseback riders while protecting ecosystem functions increases access to nature and the aesthetic beauty of the park resulting in multiple benefits including wildlife viewing which attracts tourists and businesses to Portland, provides access to recreation with many health benefits as detailed above, but requires supervision and education to protect ecological functions.

Goal 4/Action 2 Causal Chain (Figure 26) maps the action of promoting ecosystems stewardship through education, ambassador program, volunteer events, citizen science programs, and science-based research to inform adaptive management to the ecosystem function provision of intellectual stimulation and study. Measurable benefits of these programs include 1) increase awareness of actions that support urban forest conservation and need for funding management which may result in increased conservation and restoration of urban forests by landowners and increased support for funding management services through taxes or other mechanisms as described later in this report. Increased monitoring and tracking of ecosystem functions will inform adaptive management actions resulting in a more resilient and selfsustaining urban forest for future generations. 


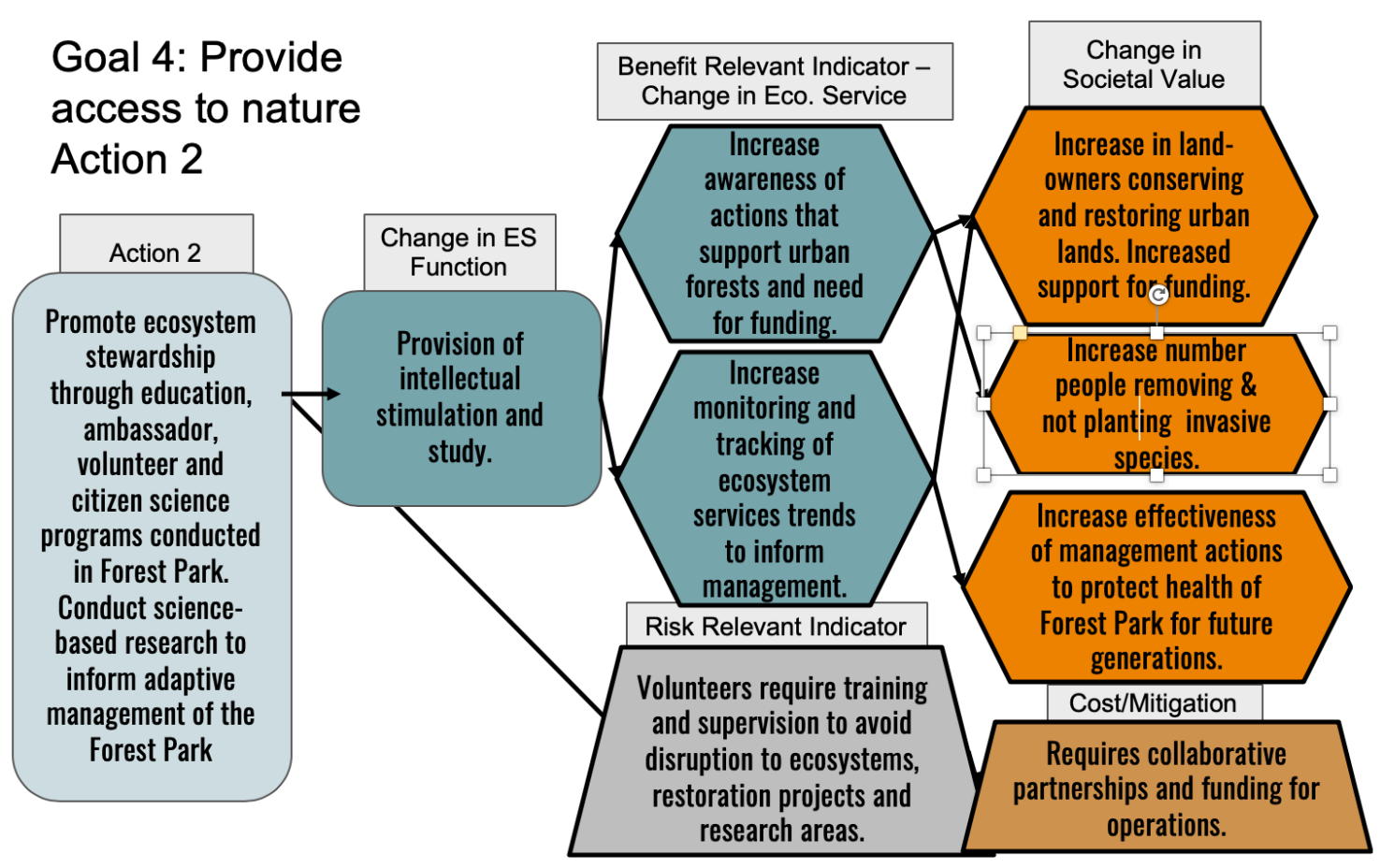

Figure 26. This causal chain maps promoting stewardship through education and events, and conducting science-based research to the provision of intellectual stimulation and study resulting in multiple benefits and values 1) increased awareness of actions need to support the health of urban forests and the need for funding which may result in increased land-owner conservation and restoration of private urban forest land and increase support for funding for Forest Park, 2) more informed people may result in fewer invasive plants being planted3) increased monitoring and tracking of ecosystem functions trends will inform management decisions that increase the effectiveness of management actions to protect the park for future generations.

\section{Benefits to Beneficiary Map}

The Urban Forest Benefits Matrix provides a summary of benefits from each action that are then aligned with beneficiaries. It is recommended each action be clearly defined by geographic area, and that the cost per unit for each action be included in the Benefits to Beneficiary map. Beneficiaries are identified in terms that can be linked to potential funding sources. For example, if the beneficiaries are residents who live in a particular neighborhood, a property tax for properties within that geographic area may be a feasible funding source. If corporations receive employee health and productivity benefits from maintained urban forests in their community, a corporate tax may be viable. If residents near urban forests benefit from management actions that protect their property from flooding, from wildfire risks, 
and increase their property value, a specific property tax in that area may be reasonable. In Figure 27 we see how the elements of the UFSF inform each other.
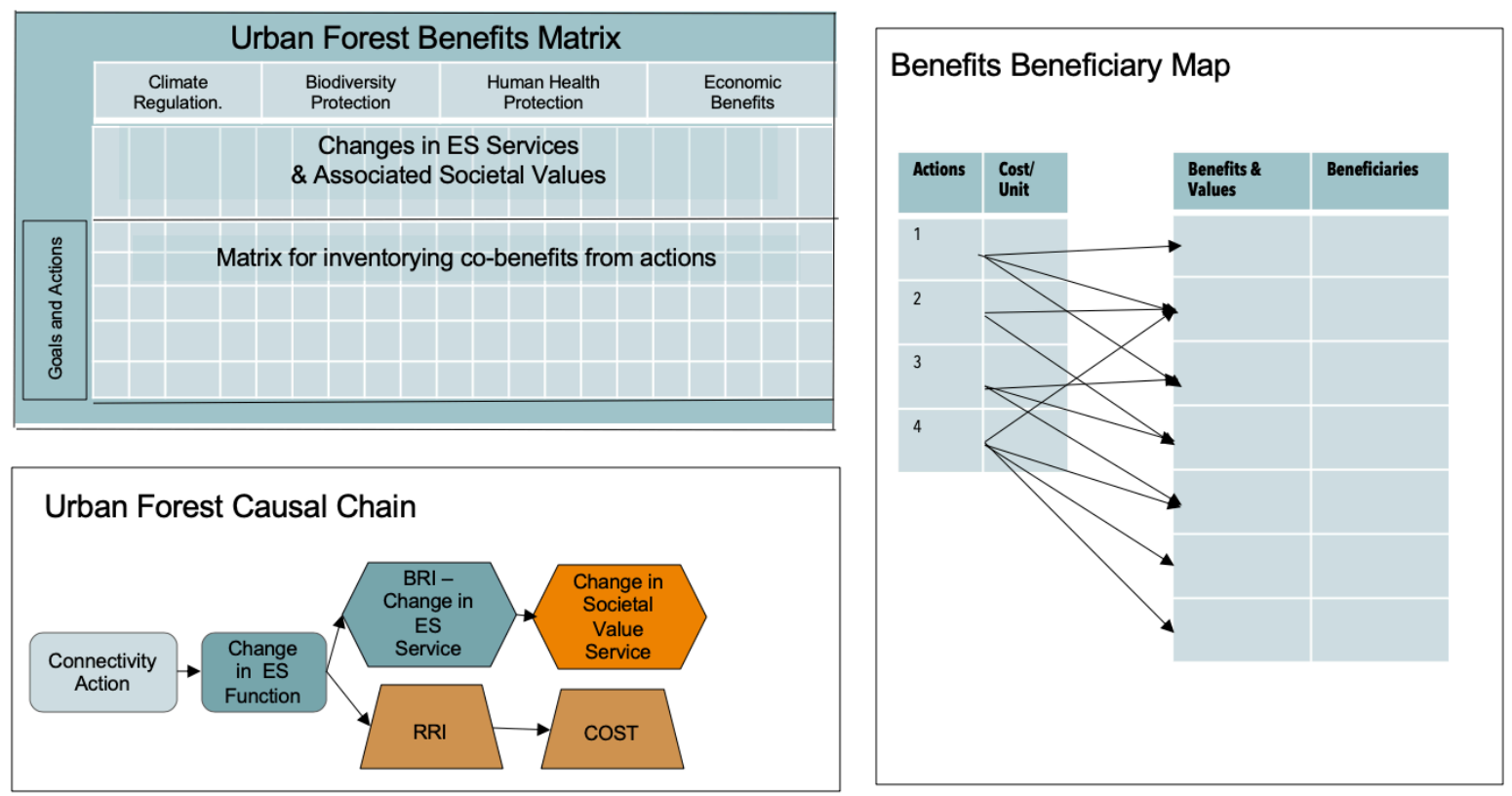

Figure 27. Three elements of the USFS are shown here. The Urban Forest Benefits Matrix captures benefits and values from the causal chains. The benefits captured in the Matrix are used to develop a Benefit to Beneficiary Map.

\section{Forest Park Case Study}

Next we map the actions to co-benefits and identify the beneficiaries of each identified by geographic area and type of beneficiary, i.e. individual, business, government. A visualization of co-benefits linked to beneficiaries is presented in Figure 28. Actions that reduce turbidity and toxins in Willamette River water benefit Metro residents, the fishing industry, property owners near Forest Park, downstream property owners who have property adjacent to the Willamette, water recreators and the Port of Portland. Actions that protect big trees and foster regeneration of trees benefit metro residents, residential and business property owners near Forest Park, the City of Portland the State of Oregon by helping meet reductions in GHG emission goals, the hospitality industry that benefits from revenues from tourism and business visitors that are lured to Portland with the promise of a hike in a forest among other its other amenities. Restoring wildlife habitats increase wildlife viewing which benefits Metro residents, residents who live near Forest Park, and the hospitality industry that benefits from non-local birdwatchers. Providing access by maintaining trails benefits Metro residents who visit the park, residential and business owners near Forest Park, and corporations adjacent to the park and/or who have employees and customers who frequent the park for recreation. 
Forest Park Benefits to Beneficiary Map

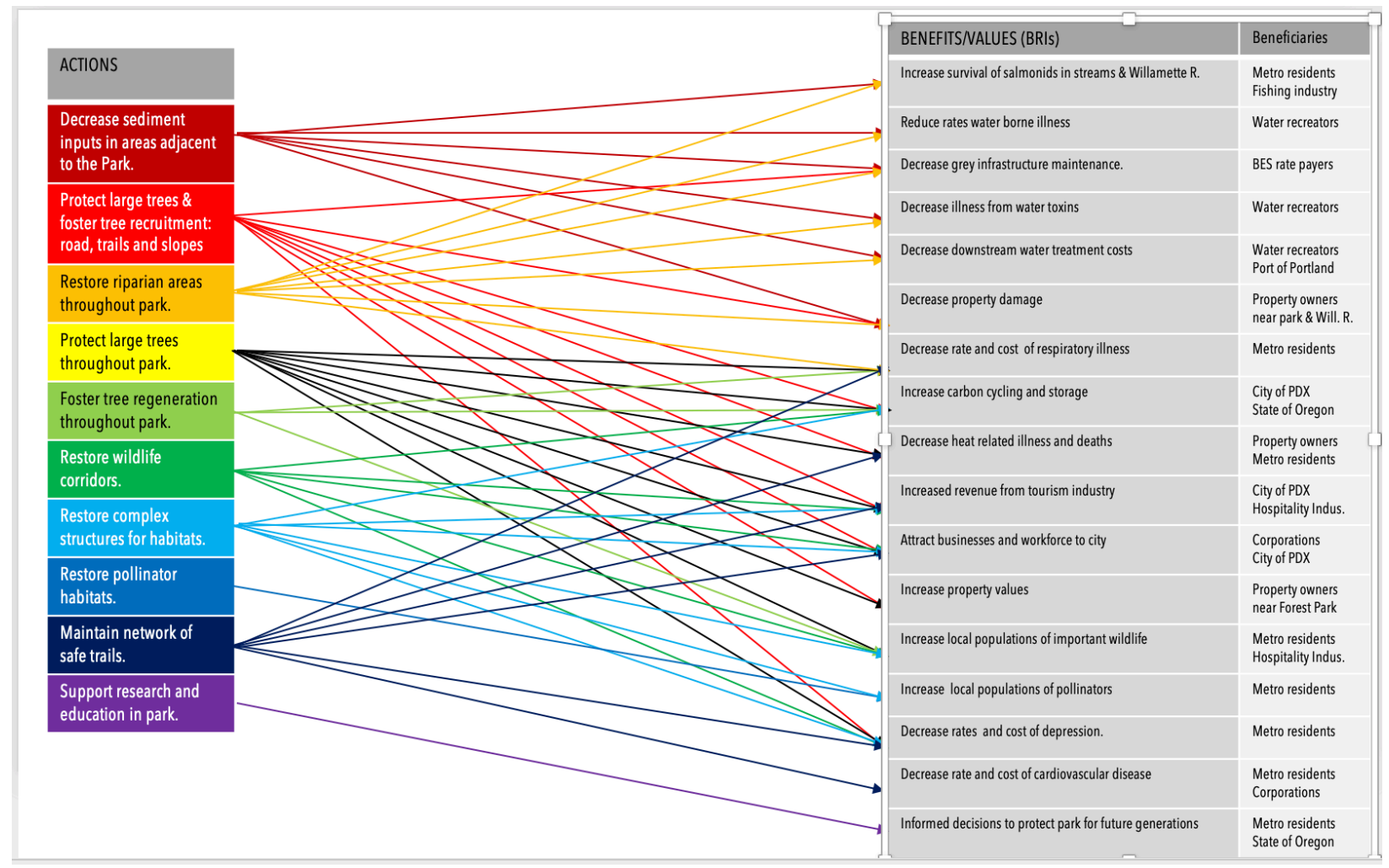

Figure 28 The Forest Park Benefits to Beneficiary Map captures the actions from the Forest Park Management Plan in the left column and the benefits from the causal chains in the near right column. To visualize the co-benefits from each, the arrows are color coded to match the color of the action boxes. In the far-right column, beneficiaries for each benefit are listed, many of them duplicates indicating where the greatest source of benefits are concentrated by geographic area and type of beneficiary, i.e. individual, business, government.

\section{Beneficiaries to Resource Map}

Finally, the UFSF maps the beneficiaries to potential resources and funding mechanisms. Funding mechanisms common for urban forests are regional property taxes and program fees. Tualatin Valley Parks and Recreation District, established in 1955, is funded by property tax and program fees (Tualatin Valley Parks and Recreation, n.d.-a), and the East Bay Recreation District in California, established in 1936, is funded by property taxes, program fees and an endowment (East Bay Recreation District, n.d.-a).

\section{Beneficiaries to Resource Map - Forest Park Case Study}

As we have established, Forest Park is held in trust by the City of Portland, and the majority of funds for managing Forest Park come from the City of Portland's general fund. Therefore, the next step in this case study explores not only alternative funding sources for Forest Park, but for all of Portland area parks. 
In a presentation to Mayor Wheeler and the Portland City Council, PP\&R Director, Adena Long and the late Parks Commissioner Nick Fish, proposed general obligation bond, special district, a local levy transient room tax; prepared food and beverage tax; cell phone tax and increased, dedicated property tax increases to fund PP\&R current and future provision of service (PP\&R, 2019). The general obligation bond, special district, local option levy and prepared food and beverage tax were recommended for further exploration. The City Council also recommended exploring an income tax (PP\&R, 2019). For the purpose of example and discussion, each of these options is included in the recommendation for funding. The Portland Mercury reported that Mayor Wheeler expressed support for creating a separate Parks District with dedicated funding following this meeting (Zielinkski, 2019). These and other funding options are shown in Figure 29. 


\section{Beneficiaries to Resource Map}

\begin{tabular}{|l|}
\hline Benefits \\
\hline Increase survival of salmonids in streams \& \\
Willamette R. \\
\hline Reduce rates water borne illness \\
\hline Decrease grey infrastructure maintenance. \\
\hline Decrease illness from water toxins \\
\hline Decrease downstream water treatment costs \\
\hline Decrease property damage \\
\hline Decrease rate and cost of respiratory illness \\
\hline Increase carbon cycling and storage \\
\hline Decrease heat related illness and deaths \\
\hline Increased tourism contributions to hospitality \\
industry \\
\hline Attract businesses and workforce to city \\
\hline Increase property values \\
\hline Increase local populations of important wildlife \\
\hline Increase local populations of pollinators \\
\hline Decrease rates and cost of depression. \\
\hline Decrease rate and cost of cardiovascular disease \\
\hline Informed decisions to protect park for future \\
generations \\
\hline
\end{tabular}

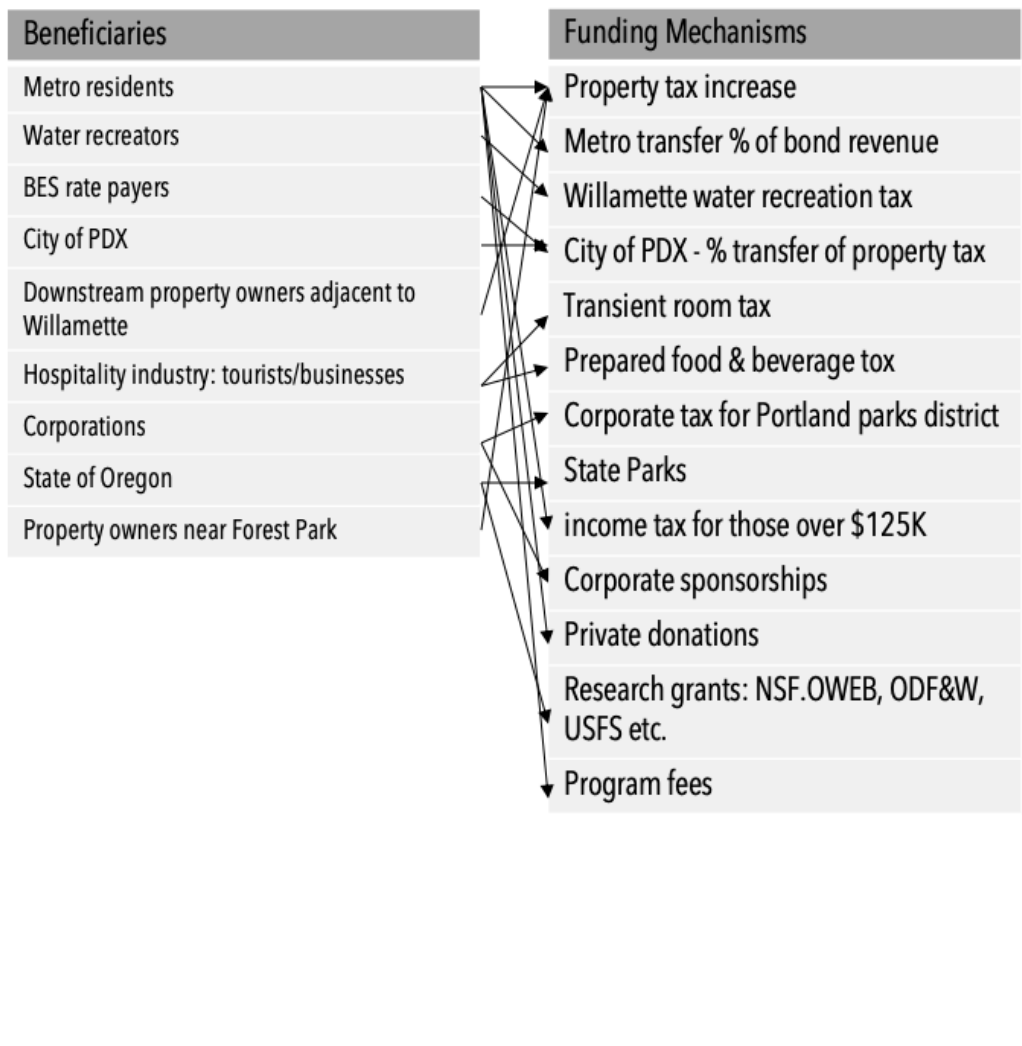

Figure 29. The Beneficiary to Resource Map for Forest Park maps the beneficiaries identified in the Benefits to Beneficiary Map to potential funding sources or mechanisms. Arrows are used to illustrate which beneficiaries would contribute via a particular funding mechanism.

\section{Funding Recommendations}

I recommend the following structure to protect and enhance the conservation of Forest Park and other Portland Park properties. I concur with the recommendations made by various past leadership of PP\&R and the present director of Portland Parks and Recreation, Adena Long, to create a separate Portland Parks District which operates in a manner similar to the Tualatin Hills Parks and Recreation District and the East Bay Parks and Recreation District which both have long histories of success. PP\&R's presentation to Mayor Wheeler and the Portland City Council did not mention funding for FPC. PP\&R's land managers and leadership consider FPC an important partner in the protection of Forest Park (Johnson, personal conversation, 2018/19; Petersen-Morgan, personal conversation, 2018/19. Long, personal conversation, 2019), therefore, funding a flow of funds from PP\&R to FPC is included in the recommendation. 
It is assumed, that responsibilities for the Portland Parks District would remain similar to what they are today. A Portland Parks District would continue to operate in conjunction with FPC. The capacity of FPC may need to increase to play a larger role in convening regional partners, leading science-based research to inform management decisions, developing partnerships with business maintaining an independent 'citizen'-led perspective on conservation and management practices in and around Forest Park.

FPC provides a unique and vital contribution to the conservation of Forest Park. From its inception as a community-led NGO guided by a board of directors, FPC acts independently from the City of Portland. As an NGO, FPC has more flexibility in fund raising, executing marketing communications, aligning with business sponsors, and accessing private property for events and research than government agency like PP\&R (Johnson, personal conversation 2018, Myers, personal conversation, 2018).

Additionally, FPC is not constrained to providing service within the bounds of the lands owned by the City of Portland. FPC convenes the Forest Park Alliance, a group of government, and non-government organizations and neighborhoods associations. Together they develop strategies to conserve areas surrounding the park through the implementation of the GFPCl, and participation in other regional strategies such as the Regional Conservation Working Group for Wildlife Connectivity (Meyers, personal conversation, 2019). FPC is responsible for maintaining the 80 miles of trails within Forest Park with assistance from PP\&R, for leading volunteer groups, stewardship and other education events.

FPC, in partnership with PP\&R, has coordinated economic research with Portland State University (PSU) and other entities that has contributed to understanding the demands for recreation and management of the park. Through this project, it was recognized that there is a missed opportunity to provide research coordination and data stewardship for ecological research conducted within Forest Park. It is recommended that FPC lead the organization of research and data stewardship for Forest Park. This recommendation is supported by PP\&R and FPC (Myers, personal conversation 2019; Johnson, personal conversation, 2019; Petersen-Morgan, personal conversation, 2019; Long, personal conversation, 2019). Specific recommendations for next steps for research and data stewardship are found later in this report.

It is recommended that funding for the Parks District come from a variety of sources to provide sustainability as illustrated in Figure 30. Sources and mechanisms include: a property tax increase on 
properties that are adjacent to natural areas, a set percentage transferred from Oregon Metro to the Parks District and FPC to fund projects that can be supported under the Parks and Nature Bond, a Willamette River water recreation tax, a set percentage transfer of existing property tax revenue from the City of Portland's general fund budget, an additional transient room tax, a tax on prepared food and beverages, a corporate tax on businesses that directly benefit from outdoor recreation, funding from State Parks (a portion of Oregon Lottery profits) to fund restoration projects that sequester carbon, and an income tax for Metro residents that make more than $\$ 125,000$, or some combination of the above.

It is further recommended that FPC receive a percentage of funding from PP\&R to fund operations and programs including management of volunteers; project funding from Metro; funding from State Parks to support stewardship and trail maintenance, corporate sponsorships to fund trail maintenance, educational events, and research, private donations to fund operations, and grants to fund research and monitoring. 


\section{Recommended Funding and Operations Model for Portland Parks District and FPC}

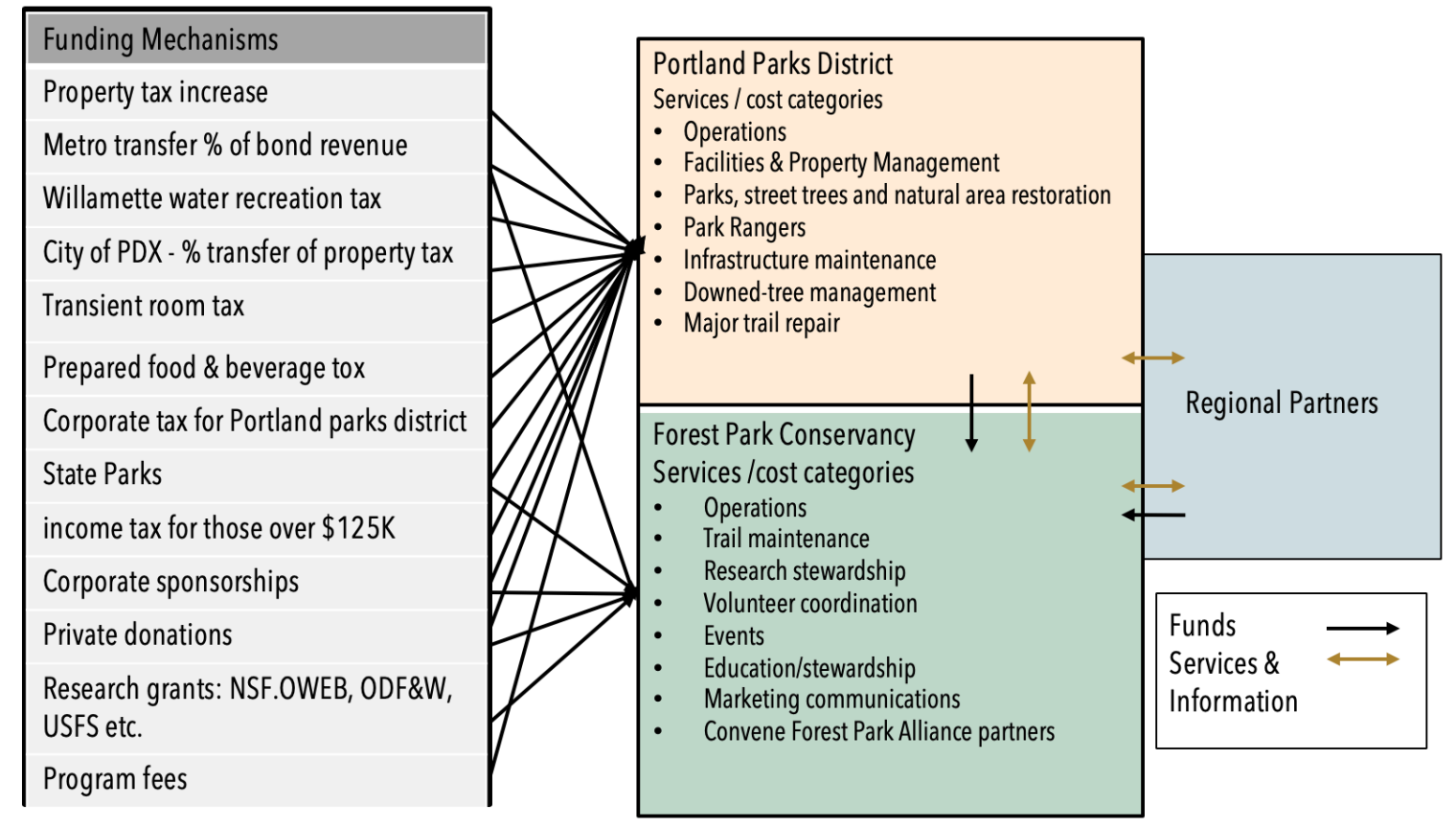

Figure 30. This funding and operations model illustrations the funding sources and funds that would be allocated to the Portland Parks District and to FPC. High level services and costs categories are listed within the Parks District and FPC boxes. Black arrows indicate a flow of funds. Brown double sided arrows represent a flow of information and services such as results of research studies, infrastructure maintenance by BES, educational program content from the Audubon Society.

\section{Recommendations for Research}

Review of studies conducted in Forest Park and analysis of monitoring data collected in restoration plots within Forest Park does not affirm that management practices are achieving their aim of restoring the park to a self-regenerating resilient forest. Key areas of study are recommended to better inform management actions. It is not clear whether ivy is driving reduced tree establishment or if the spread of ivy is the result of the same factors that negatively influence late-successional conifer recruitment. Outstanding research questions are categorized and presented here.

\section{General forest health:}

- Can Forest Park's future trajectory be managed to maintain its biodiversity and ecosystem services?

- What is negatively impacting tree health and tree recruitment in Forest Park? Is it air pollution, soil degradation, lack of microsite conditions, insufficient population density for reproduction or other 
factors?

- What understory and tree species will adapt best to changing climates?

Ivy Ecology \& Management

- Where and how fast is ivy spreading? Does it align with management restoration areas?

-Should restoration timelines be accelerated manage the ivy invasion before it reaches a tipping point?

-What is the impact of manual ivy removal on soils, the herbaceous layer and invertebrate populations?

-What is the impact of herbicide applications on soil metals which are known to bind with

organophosphates like Glyphosate and Triclopyr?

-What is the impact of herbicide application on invertebrate populations and mycorrhizae?

-What revegetation strategies will enhance competition with ivy?

-Are restoration practices restoring wildlife habitats as intended?

-How is ivy impact nitrogen cycling? Is decreased nitrogen the cause of the observed decrease in species richness in the herbaceous layer, or is there some other cause?

-What are ivy's effects on erosion and tree blowdown in Balch Creek?

-How is ivy interacting with little-studied environmental factors such as exotic earthworms or soil fungi?

\section{Need for Data}

Specific recommendations for addressing data gaps are detailed in the Impact of IVy: Management Considerations for Forest Park and Assessment of Current and Future Conditions of Forest Park:

Management Considerations (Hardy et al unpublished studies 2018, 2019) and are summarized below.

Plot Scale Data

As longer-term post-treatment data become available from the restoration plots in the Balch Creek watershed of Forest Park, it may become possible to determine the effects, both positive and negative, of invasive plant treatment (whether chemical or manual) on non-target vegetation and ecological functions, as well as track the long-term efficacy of those treatments on the targeted species, and what revegetation prescriptions are used and how they fare over time. Additional data collection would involve establishing additional untreated control plots. Control sites would be part of a system of long-term protected research plots to study soil ecology, revegetation methodologies to restore forest function, tree regeneration issues and strategies, and other management questions. 


\section{Need for Landscape-scale Data}

In addition to plot-scale data, there is a need for landscape-scale geographical data. For example, the 2004 City of Portland Natural Resources Inventory provides a valuable broad snapshot of past ecological conditions in Forest Park but is outdated and low-resolution. An updated inventory combining remote sensing data, ground surveys, and other methods is needed, with a particular focus on mapping canopy gaps, large trees and old-growth remnants to protect, forest regeneration, understory communities, coarse woody debris, and population densities and distributions of priority invasive species such as ivy. Updated data would allow for future spatial and ecological analyses of critical processes and management issues affecting the ecological trajectory of the entire park and inform how to prioritize management decisions and where to direct resources. Such analyses could include a more detailed assessment of ivy and its ability to invade the landscape, modeling of forest succession dynamics, and the spatial impacts of roads, trails, and other human disturbances.

The spatial analysis methodologies developed and documented in the Assessment of Future Conditions document (Hardy et al., unpublished paper. 2019) can be applied to LIDAR datasets representing other areas and time periods, enabling a comparison of canopy conditions between different locations, assess changes over time, and even develop important environmental variables for the entire park. The first such analysis can be conducted when Metro's scheduled Fall 2019 LIDAR data layers become available, but data from before 2014 can be used as well to understand historic trends and compare rates of change.

\section{Historical Data}

Further study should also focus on reconstructing the land-use and disturbance history of the $\mathrm{GFPCl}$ and quantify the legacy effects which might be invisibly shaping current conditions and future trends, including plant community composition (Johnson et al, 2015) and species invasions (Hobbs, 1989). While logging, fires, major soil and hydrological disturbances, and intentional ivy propagation are all known to have occurred in Forest Park, only wildfire has been well-documented in both spatial and temporal terms. Wider dendrochronological sampling, canopy structure analysis, woody debris surveys, and historical imagery might help infer missing details (Spies et al., 1988). 
Long-term Trends:

Long-term ecosystem monitoring enables observation of complex and dynamic changes over time which can help infer the answers to difficult questions such as how quickly ivy and other invasive organisms are spreading; whether understory communities are stable or declining in different parts of the park; if urban environmental stresses are becoming more impactful.

I re-emphasize here the need for baseline and monitoring data to describe the changes occurring to ecosystem services within the park to inform management actions to restore function and to value the change in these services. As environmental economists Banzhof \& Boyd point out, snap shots of ecological condition do not help managers make a choice of action. Decision makers are faced with questions about what types of ecological conditions are better than others - lands with trees or lands with ivy, for example. Economic evaluations rely on science to describe the change in ecological systems to assess the value of changes in human services which informs tradeoffs and help set priorities (Banzhof \& Boyd, 2005)

\section{Other Considerations}

Establishment of a separate Portland Parks District funded through new taxes is a concept that has been discussed for many years and has the support of the current mayor. Recent events make the continued discussions challenging to pursue at this time: the significant negative economic impact of the coronavirus, and the recent passage of three bond measures in the City of Portland and Metro region that tax the same individuals and organizations targeted for the funding of the Portland Parks District.

\section{Impact of Coronavirus}

Budget shortfalls predicted as a result of the response to the Coronavirus by the City of Portland and State of Oregon will have unknown impact on funding for parks and conversation funding in general. Mayor Ted Wheeler originally predicted a budget shortfall of $\$ 75$ million for $2020-21$, but later adjusted the shortfall to be as lows at $\$ 7$ million by taking savings from reserves, set asides and by delaying certain programs (City of Portland, 8 May 2020). The specific impacts on PP\&R and Forest Park staffing and projects are unknown. State of Oregon economists predict a 2020-21 budget shortfall of $\$ 2.7$ billion and another $\$ 7.8$ billion by 2025 for a total of $\$ 10.5$ billion (VanderHart, 20 May 2020). Oregon Lottery profits are predicted to decline 20-40\% (\$250 - \$500 million) in 2020-21 (Sickenger, 27 April 2020), which 
directly impact State Parks and OWEB funding as each agency receives $7.5 \%$ of Oregon Lottery profits as a primary source of funding (Oregon Lottery, n.d.-a).

Revenues from the hospitality industry have taken a significant hit from bans on travel and the closing of bars, taverns and restaurants. Transient room revenues and food and beverage revenues have been significantly impacted with length of time for recovery uncertain.

\section{Metro and City of Portland Bond Measures}

In the past two years voters have approved bonds to fund green energy, parks and nature and supporting housing services for homeless. Clearly votes are willing to approve for funding for causes they find important including conservation. The challenge is that none of these funding measures directly benefit $P P \& R$ and FPC. A portion of the money from the Metro bond supports specific programs for PP\&R and FPC, but the majority of the Metro money is used to acquire new park lands and is awarded through competitive grants (Metro n.d.-a). Voters and businesses may be reluctant to support additional taxes.

In November 2018, Portland voters adopted Ballot Measure 26-201, the Portland Clean Energy Community Benefits Initiative (referred to hereafter as the Clean Energy Surcharge or CES). CES imposes a 1\% surcharge on the retail sales within Portland of certain large retailers (City of Portland n.d.-a)

In May 2020, Metro voters passed a ballot measure for the $1 \%$ tax on incomes above $\$ 125,000$ a year for individuals or $\$ 200,000$ a year for joint filers in the Portland metro area and the $1 \%$ tax on businesses that bring in more than $\$ 5$ million from business conducted within Metro's boundary. The taxes go into effect in 2021 and continue through 2030 (Metro 19 May 2020).

In November 2019, the Metro Parks and Nature bond was passed which renews the current property tax for Metro residents of $\$ 0.19$ per $\$ 1000$ of assessed value (Zheng, 5 November 2019). The good news is that voters approved all three bonds, therefore there may be support for additional taxes increases that support the parks system which is important to them. In the presentation to Mayor Wheeler and the City Council, PP\&R revealed that in 2017 93\% of Portlanders surveyed said that it is important to maintain existing parks, natural areas and facilities (PP\&R 2019). 
The City of Portland and Metro are considering additional taxes to fund transportation programs potentially reducing the public's willingness to support a Park's District. A more comprehensive approach to taxation needs to be considered by the City of Portland in partnership with Metro to prioritize initiatives rather than continuing to piece-meal the approach to taxes and fees.

\section{Summary}

It is clear that the people of Portland love Forest Park and value its services. It is important to our wellbeing as city dwellers, and for the flora and fauna that depend on it for life. It protects our air, our water, our fish, our physical and mental health, and provides economic opportunities for the city attracting tourists, businesses, residents and supports a restoration economy. Voters, civic leaders and businesses agree, but few understand what it takes to manage a such a novel and highly disturbed forested ecosystem. The case must be made clear.

As pressures on Forest Park increase with rising populations, climate change, threats from invasive species, and increased demand for recreation; the importance of management decisions on natural areas also increases. Through a program of active adaptive management; informed through a collaboration of land-managers and researchers; the city has an opportunity to gather and analyze data, publish results, and iterate management practices to protect Portland's Forest Park for future generations of humans and wildlife. Benefits derived from resilient forested ecosystems that provide recreation to the people of the city must be aligned with beneficiaries and adequate funding to support management programs must be dedicated and protected through the creation of a Portland Parks District, or similar government organization in collaboration with a citizen-led conservation NGO potentially expanding the role and capacity of the Forest Park Conservancy.

In this uncertain economic climate, it may be challenging to find support to create a Parks District through tax increases, but it is time to rally support. Priority should be given to formalizing the Forest Park research consortium to build a stronger case for management needs, and to increase funding for FPC operations through increased contributions from corporate sponsorships and individual donors to educate the people of Portland as to the need for funding and stewardship of our natural lands. 


\section{References}

Addessi, Andrew D. (2017) Urban Impacts to Forest Productivity, Soil Quality, and Canopy Structure in Forest Park, Portland, Oregon (Unpublished thesis) Portland State University, Portland, Oregon. Retrieved from: https://pdxscholar.library.pdx.edu/open access etds/3881/

Banzhaf, S., Boyd, J. (2005) The architecture and measurement of an ecosystem services index. Resources for the Future. Retrieved from:https://www.researchgate.net/publication/24122862_The_Architecture_and_Measurement_of_an_Ecosystem_Servic es_Index

Baro, Francesc, Calderon-Argelich, Amalia, Langemeyer, Johannes Connolly, James J.T. (2019) Under one canopy? Assessing the distributional environmental justice - implications of street tree benefits in Barcelona. Environmental Science and Policy 102:54-64

Barrevro, P, Dempsey-Stein, J., Kent, C, Machado, A. (2016) Results of five focus groups conducted in spring 2016. Retrieved from; https://www.pdx.edu/econ/sites/www.pdx.edu.econ/files/EconValue ForestParkEcosystemServices FocusGroupResults Se pt2016.pdf

Baumgartner, S., Strunz, S., (2014) The economic insurance value of ecosystem resilience. Ecological Economics 101: 21-32 doi.org/10.1016/j.ecolecon.2014.02.012

Berland, A., Shiflett, S. A., Shuster, W. D., Garmestani, A. S., Goddard, H. C., Herrmann, D. L., \& Hopton, M. E. (2017). The role of trees in urban stormwater management. Landscape and Urban Planning, 162, 167- 177.

https://doi.org/10.1016/j.landurbplan.2017.02.017

Biggerstaff, M.S., Beck, C.W. (2007) Effects of English Ivy (Hedera helix) on seed bank formation and germination. The American Midland Naturalists $157(2)$

Bluffstone, R., Burchett, R., Eiwaz, K., Ingebretsen, E., Schaffer, P., Toth, S., et al. (2015) Estimating the recreational value of Portland's Forest Park. Retrieved from: https://pdxscholar.library.pdx.edu/econ_fac/122/

Bolund, P. \& Hunhammar, S. (1999). Ecosystem services in urban areas. Ecological Economics 29:293-301

Bucsher, Bram; Sullivan, Sian; Neves, Katja; Igo, Jim \& Brockington, Dan (2012) Towards a Synthesized Critique of Neoliberal Biodiversity Conservation. Capitalist Nature: 23(2): 4-3

Broshot, N.E. (2007) The influence of urbanization upon forest stand dynamics in Northwestern Oregon. Urban Ecosyst 10:285-298

Broshot,.N.E. (2011) Mortality and recruitment in an urban forest (Forest Park in Portland, Oregon) between 1993 and 2003. Urban Ecosyst 14:553-567

Brundtland, G.H. (1987) Our Common Future. Retrieved from: https://sustainabledevelopment.un.org/content/documents/5987ourcommon-future.pdf

Bureau of Environmental Services (2017) Terrestrial Ecology Enhancement Strategy. Retrieved: https://www.portlandoregon.gov/bes/51052

Center for Disease Control (2015) 500 Cities.Local Data for Better Health. Retrieved from https://nccd.cdc.gov/500_Cities/rdPage.aspx?rdReport=DPH_500_Cities.InteractiveMap\&islCategories=HLTHOUT\&isIMeasu $\underline{\text { res }=\text { ARTHRITIS\&isIStates }=41 \& \text { rdRnd }=63124}$

Center on Budget and Policy (2018) Retrieved from: https://www.cbpp.org/topics/state-budget-and-tax

Chang, K.G., Chien, H. (2017) The influences of landscape features on visitation of hospital green spaces - a choice experiment approach. International Journal of Environmental Research and Public health: 14, 724. Doi: 10.3390/ijerph14070724 
City of Portland Bureau of Environmental Services (2019) Portland watershed health index. Retrieved from: https://www.portlandoregon.gov/bes/article/536274

City of Portland (n.d.-a) Portland clean energy initiative. Retrieved from: https://www.portlandoregon.gov/revenue/78324

City of Portland (8 May 2020) Mayor Wheeler's Proposed Budget for 20-2021. Retrieved from: https://beta.portland.gov/wheeler/covid19-updates-mayor-wheeler

City Club of Portland. (2010). Forest Park: A Call for Action. Retrieved from: https://www.portlandoregon.gov/fish/article/301819 (NOT ACTIVE)

City of Portland (2018) 2035 Comprehensive Plan. Retrieved 10/31/2018: https://www.portlandoregon.gov/bps/2035-comp-plan.pdf.

Portland Parks \& Recreation (2011) Forest Park Desired Future Conditions. Retrieved 11/2/2018: https://www.portlandoregon.gov/parks/article/469536

City of Portland (2018) City of Portland Budget Dashboard. Retrieved 11/4/2018: https://www.portlandoregon.gov/cbo/article/687011

City of Portland and Multnomah County (2015) Climate Action Plan. Retrieved https://www.portlandoregon.gov/bps/article/531984

City of Portland and Multnomah County (2014) Climate Change Preparation Strategy: Risk and Vulnerabilities Assessment. Retrieved from: https://beta.portland.gov/sites/default/files/2019-07/risk-vulnerabilities-assessment-press.pdf

Clark, N.E., Lovell, R., Wheeler, B.W., Higgins, S.L., Depledge, M.H, Norris, K. (2014). Biodiversity, cultural pathways, and human health a framework. Trends in Ecology \& Evolution. doi.org/10.1016/j.tree.2014.01.009

Clark, J., Kruidenier, W., \& Wolf, K. (2005). National Research Plan for Urban Forestry: 2005-2015.

Copp, Sarah R. (2014) Community level impacts associated with the invasion of English ivy (Hedera spp.) in Forest Park: a look at the impacts of ivy on community composition and soil moisture. (Unpublished thesis). Environmental Science and Management. Portland State University, Portland, Oregon.

Costanza, R., d'Arge, R., de Groot, R., Farber, S., Grasso, M., Hannon, B., Limburg, K., Naeem, S., O’Neill, R.V., Paruelo, J., Raskin, R.G., Sutton, P., \& van den Belt, M. (1997). The value of the world's ecosystem services and natural capital. Nature 387, 253-260

Costanza, R.; deGroot, R., Sutton, P., van der Ploeg, S., Anderson, S.J., Kubiszewski, I., Farber, S. \& Turner, R. K. (2014). Changes in the global value of ecosystem services. Global Environmental Change 26:152-158

Daanen, H. A. M., Jonkhoff, W., Bosch, P., \& Ten Broeke, H. (2013). The effect of global warming and urban heat islands on mortality, morbidity and productivity in The Netherlands. In J. D. Cotter, S. J. E. Lucas, \& T. Mundel (Eds.), International Conference of Environmental Ergonomics (pp. 16-19). Queenstown, New Zealand: International Society for Environmental Ergonomics.

Department of Environmental Quality (n.d.-a) Air quality in the Portland region. Retrieved from: https://www.oregon.gov/deq/aq/Pages/AQ-Portland.aspx

Dissanayake, S., Myers, R. (2017, 2018, 2019) Personal conversations

Donovan, G. H., \& Butry, D. T. (2009). The value of shade: estimating the effect of urban trees on summertime electricity use. Energy and Buildings, 41(6), 662-668. https://doi.org/10.1016/j.enbui Id.2009.01.002

Donovan, G.H., Butry, D.T. (2010) Trees in the city: valuing street trees in Portland, Oregon. Landscape and Urban Planning 94/2: 7783. https://doi.org/10.1016/j.landurbplan.2009.07.019

Donovan, G.H., Michael, Y.L., Butry, D.T., Sullivan, A.D. \& Chase, J.M. (2011) Urban trees and the risk of poor birth outcomes. Health \& Place 17:390-393 
Donovan, G.H., Butry, D.T., Michael, Y.L., Prestemon, J.P., Liebhold, A.M., Gatziolis, D. \& Mao, M.Y. (2013). The relationship between trees and human health - evidence from the spread of the emerald ash borer. American Journal of Preventive Medicine 44(2):139-145

Donovan, G., Gatziolis, D., Longley, I. \& Douwes, J. (2018) Vegetation diversity protects against childhood asthma: results from a large New Zealand birth cohort. Nature Plants 4(6). https://doi.org/10.1038/s41477-018-0151-8

Dornier, A. \& Cheptou, P. (2012). Determinants of extinction in fragmented plant populations: Crepis sancta (asteraceae) in urban environments. Oecologia 169, 703-712 doi:10.1007/s00442-011-2229-0

Dratva, J, Zemp, E., Felber Dietrich, D., Bridevauz, P.O., Rochat, T., Schindler, D. \& Gerbase, M.W. (2010). Impact of road traffic noise annoyance on health-related quality of life: Results from a population-based study. Quality of Life Research 1:37-46

Dlugosch, K.M. (2005) Understory community changes associated with English ivy invasions in Seattle's urban parks. Northwest Science 79(1):52-59

Dresner, M., Van Winkle, J., Franz, S.C. (2017) Tree composition and abundance patterns differ in two watersheds of Forest Park, a large Pacific Northwest urban forest. Arboricultural Journal 39(4):208-225.

East Bay Regional Parks District (n.d.-a) Brochure. https://www.ebparks.org/civicax/filebank/blobdload.aspx?blobid=24326

East Bay Regional Parks District (2019) 2019 budget. https://www.ebparks.org/civicax/filebank/blobdload.aspx?blobid=32266

Elmqvist, T., Setala, H., Handel, S.N., van der Ploeg, S., Aronson, J., Blignaut, J.N., Gomez-Baggerthun, E., Nowak, D.J., Kronenberg, J., deGroot, R. (2015). Benefits of restoring ecosystem services in urban areas. Current Opinion in Environmental Sustainability. 14:101-108

Ervin, D., S. Vickerman, S. Ngawhika, F. Beaudoin, S. Hamlin, E. Dietrich, P. Manson, and J. Schoenen. (2014) Principles to guide assessments of ecosystem service values, first revised edition. Portland, Oregon: Cascadia Ecosystem Services Partnership, Institute for Sustainable Solutions, Portland State University

Ervin, David (2018) (Personal conversation) Professor Emeritus Environmental Science and Management and Economics, Portland State University.

Escobedo F.J., Kroeger T. \& Wagner J.E. (2011). Urban forests and pollution mitigation: analyzing ecosystem services and disservices. Environ Pollut 159:2078-2087.

Escobedo F.J. \& Nowak, D.J. (2009). Spatial heterogeneity and air pollution removal by an urban forest. Landscape Urban Planning 90:102-110.

Ettinger, A.K., Lee, B.R., Montgomery, S. (2017) Seed limitation and lack of downed wood, not invasive species, threaten conifer regeneration in an urban forest. Urban Ecosystems 20(877):877-887

Fahy, B., Brennenman, E., Chang, H., Shandas, V. (2019). Spatial analysis of urban flooding and extreme heat hazard potential in Portland Oregon. International Journal of Disaster Risk Reduction 39:10117

Forest Park Conservancy, Portland Parks and Recreation, METRO, West Multnomah Soil and Water Conservation District. (2016) Uniform Protocol Monitoring for the Greater Forest Park Ecosystem. Retrieved 10/15/2018: https://www.forestparkconservancy.org/conservancy/initiative/

Forest Park Conservancy. (n.d.a-). Retrieved from https://forestparkconservancy.org/conservancy/

Fish, N., (2010) Protecting the crown jewel of our parks system. Retrieved from: https://www.portlandoregon.gov/fish/article/308038

Gerwing, J. (2018) (Personal conversation) Associate Professor, Environmental Science and Management, Portland State University. 
Gildof-Gunnarsson, A., \& Ohstrom, E., (2007): Noise and well-being in urban residential environments: The potential role of perceived availability to nearby green areas. Landscape and Urban Planning 83(1-2): 115-126

Gilliam, F.S. (2007) The ecological significance of the herbaceous layer in temperate forests ecosystems. Bio Science 57(10).

Green, T.L., Kronenberg, JK., Anderson, E., Elmqvist, T., Gomez-Baggerthun, E. (2016) Insurance value of green infrastructure in and around cities. Ecosystems 19: 1051-1063. Doi: 10.1007/s10021-016-9986-x.

Hardy, C., Butler, E., Hadzinski, B. (unpublished paper 2018) Impact of English Ivy: Management considerations. Middleeartheconomcis.ccom

Hardy, C., Butler, E., Schielf, S., Gayaldo, J., Ryan, S. (unpublished paper 2019) Assessment of current and future conditions of Forest Park: Management considerations. Retrieved from; Middleeartheconomics.com.

Hardy, C, de Rivera, C., Bliss-Ketchum, L., Butler, R., Dissanayake, S., Horn, D., Huffine, B., Temple, A., Vermeulen, M, Wallace, H. (in review 2020) A framework for transformative change for functional urban ecosystems: incorporating ecosystem connectivity into planning for livable cities. Retrieved from: Middleeartheconomcis.com

Hardin, P.J. et al. (2007) The effect or urban leaf area on summertime urban surface kinetic temperatures: A Terre Haute case study. Urban Forestry and Urban Greening 6:63-72. doi:10.1016/j.ufug.2007.01.005

Harvey, David (2005) A Brief History of Neoliberalism. Oxford Press.

Harvey, David (2004) The 'new' imperialism: accumulation by dispossession. Socialist Register 40: 63-87

Hauser, Daniel (2018) Property tax limits weaken services in Oregon. The Portland Tribune. Retrieved 5/17/2019: https://www.ocpp.org/2018/08/01/property-tax-limits-weaken-services-oregon/

Hauser, D. (2018) Property tax limits weaken services in Oregon. Retrieved from: https://pamplinmedia.com/fgnt/37-opinion/402286298120-hauser-property-tax-limits-weaken-services-in-oregon

Hobbs, R. J. (1989). The nature and effects of disturbance relative to species invasions. In Biological Invasions: A Global Perspective (pp. 389-403). Chichester, NY: John Wiley \& Sons.

Holloway, L., Rosenstiel, T. (2013). Physiological response of invasive ivy (Hedera spp.) to the seasonal light cycle: taking photosynthetic advantage of winter canopy loss. Poster presented at the Northwest Science Association Annual Meeting, Portland, Oregon. Abstract received from: http://www.northwestscience.org.

Huste, A. \& Boulinier, T. (2007). Determinants of local extinction \& turnover rates in urban bird communities. Ecological Applications 17:1 168-180.

Johnson, A. L., Tauzer, E. C., \& Swan, C. M. (2015). Human legacies differentially organize functional and phylogenetic diversity of urban herbaceous plant communities at multiple spatial scales. Applied Vegetation Science, 18(3), 513-527.

Johnson, M. (2018, 2019) Personal conversations,. Forest Ecologist, Portland Parks and Recreation.

Keeley, A. T. H., Ackerley, D. D., Cameron, D. R., Heller, N. E., Huber, P. R., Schloss, C. A., Thorne, J. H., \& Merenlender, A. N. (2018). New concepts, models, and assessments of climate-wise connectivity. Environmental Research Letters, 13(7), 073002.

Kravchenko, J., Abernaethy, A.P., Fawzy, M., Lyerly, H.K. (2013). Minimization of heatwave morbidity and mortality. American Journal of Preventive Medicine 44(3):274-282

Kubota, T. (2017). Stanford research finds that diversity of large animals plays an important role in carbon cycle. Retrieved from: https://news.stanford.edu/2017/10/09/animal-biodiversity-important-part-carbon-cycle/ 
Li, D., \& Sullivan, W. C. (2016). Impact of views to school landscapes on recovery from stress and mental fatigue. Landscape and Urban Planning,148, 149-158. https://doi.org/10.1016/j.landurbplan.2015.12.015

Leachman, Michael (2006) The Great Corporate Tax Shift: Undercutting Oregon's Economy and Quality of Life. OCPP. Retrieved 5/17/2019:

Mac Innis, Tyler \& Ordonex, Jan Carolos (2016) The Gaming and Decline of Oregon Corporate Taxes. OCPP. Retrieved 5/17/2019: https://www.ocpp.org/2016/06/29/executive-summary-corporate-tax-decline/

McIntyre, J.K., Davis, J.W., Hinman, C., Macineale, K.H., Anulacion, B.F., Scholz, N.L., Stark, J.D. (2015). Soil bioretention protects juvenile salmon and their prey from the toxic impacts of urban stormwater runoff. Chemosphere 132: 213-219

Millennium Ecosystem Assessment (2005) Ecosystem services and human well-being: synthesis. Island Press, Washington D.C.

McCarthy, M.A., Possingham, H.P (2007) Active Adaptive Management for Conservation. Conservation Biology 21(4):956-963.

Metro (19 May 2020) Supportive housing services: addressing homelessness in greater Portland. Retrieved from: https://www.oregonmetro.gov/public-projects/supportive-housing-services

Metro (n.d.-a) Nature in Neighborhoods grants. Retrieved from: https://www.oregonmetro.gov/tools-partners/grants-andresources/nature-grants

Mitchell, M. G. E., Suarez-Castro, A. F., Martinez-Harms, M., Maron, M., McAlpine, C., Gaston, K. J., ... Rhodes, J. R. (2015). Reframing landscape fragmentation's effects on ecosystem services. Trends in Ecology and Evolution, 30(4), 190-198.

Myers, R. et al. (2013) Greater Forest Park Conservation Initiative. Retrieved from: www.forestparkconservancy.org

Myers, R. (2017, 2018, 2019, 2020) Personal conversations. Executive Director, Forest Park Conservancy.

Netusil, N.R.; Chattopadhyay, S. \& Kovacs, K.F. (2010) Estimating the demand for tree canopy: A Second-stage Hedonic Price Analysis in Portland, Oregon. Land Economic 86/2: 281-293 doi: 10.3368/le.86.2.281

Nowak, D.J, Crane, D.E., Dwyer, J. F. (2002) Compensatory value of urban trees in the United States. Journal of Arboriculture: 28(4).

Nowak D.J., Crane, D.E. (2002) Carbon sequestration and storage by urban trees in the USA. Environmental Pollution 116: $381-389$. Retrieved: https://www.nrs.fs.fed.us/pubs/jrnl/2002/ne_2002_nowak_002.pdf

Nowak, D.J. \& Greenfield, E.J. (2018). US urban forest statistics, values and projections. Journal of Forestry 116(2):164-177 doi: 10.1093/jofore/fvx004

Netusil, N., Chattopadhyay, S., Kovacs, K. (2010) Estimated the demand for tree canopy: a second stage hedonic price analysis in Portland, Oregon. Land Economics 86: 281-293. doi: 10.3368/le.86.2.281

Olander, L.P., Johnston, R.J., Tallis, H., Kagan, J., Maguire, L.A., Polasky, S., Urban, D., Boyd, J., Wainger, L. \& Palmer, M. (2018). Benefit Relevant Indicators: Ecosystem services measures that link ecological and social outcomes. Ecological Indicators 85: 12621272

Oregon Historical Society (n.d.-a) First peoples of the Portland basin. Retrieved from: https://oregonhistoryproject.org/narratives/commerce-climate-and-community-a-history-of-portland-and-itspeople/introduction-3/first-peoples-in-the-portland-basin/\#.Xsr-ly-ZOuU

Oregon Lottery (n.d.-a) Distribution of lottery funds. Retrieved from: https://oregonlottery.org/about/oregon-lottery-information/howlottery-funds-are-allocated

Petersen-Morgan, K (2018. 2019) Personal conversations. Natural Areas Manager, Portland Parks and Recreation.

Pew Charitable Trusts (2012) The Local Squeeze. Washington D.C.: Pew Charitable Trusts. Retrieved from: https://www.pewtrusts.org/en/research-and-analysis/reports/0001/01/01/the-local-squeeze 
Polanyi, Karl (1944 (2001)). The Great Transformation. vii-xxxiii and 71-80 (Introduction by Fred Block, and "The Self-Regulating Market").

Portland Bureau of Environmental Services (n.d.-a) Willamette River Tributaries Report Card. Retrieved from: https://www.portlandoregon.gov/bes/article/744242Portland Parks and Recreation and the Bureau of Environmental Services (1995) Forest Park Natural Resource Management Plan. Retrieved 10/31/2018:

Portland Bureau of Planning and Sustainability (2018) 2035 Comprehensive Plan. Retrieved 5/19/2019: https://www.portlandoregon.gov/bps/2035-comp-plan.pdx

Portland Parks and Recreation (n .d.-a) Retrieved 11/8/2018: https://www.portlandoregon.gov/parks/47820

Portland Parks and Recreation (2019) A Sustainable Future. Retrieved from: https://www.portlandoregon.gov/parks/80219

Portland Parks and Recreation (2010) Open spaces and park development: 1851-1965. Retrieved from: https://www.portlandoregon.gov/parks/38306?a=286454

Portland Parks and Recreation. (2011) Forest Park ecological prescriptions. Retrieved from: https://www.portlandoregon.gov/parks/article/376345

PP\&R (2014) Protect the Best - Invasive Vegetation Management Program Biannual Report. Retrieved 11/29/2018: https://www.portlandoregon.gov/parks/article/342777

Portland Parks and Recreation (2016) Renew Forest Park. Retrieved 11/8/2018: https://www.portlandoregon.gov/parks/article/539389

Portland Parks and Recreation (2012) Forest Park Wildlife Report. Retrieved: https://www.portlandoregon.gov/parks/article/427357

Portland Parks and Recreation and Potland State University (2012) Foreset Park Recreation Survey. Retrieved from: https://www.portlandoregon.gov/parks/article/317545

Pregitzer, C.C., Charlop-Powers, S., McCabe, C., Hiple, A., Gunther, B., Bradford, M.A. (2012) Untapped Common Ground: The Care of Forested Natural Areas in American Cities. https://naturalareasnyc.org/content/national/nac careofurbannature loressingles.pdf?1553522646

Query, Toby (2018) (Personal conversation) Plant Ecologist, Bureau of Environmental Services, Portland, Oregon.

Radeloff, V.C., Williams, J.W., Bateman, B.L., Burke, K.D., Carter, S.K., Childress, E.S., Cromwell, K.J., Gratton, D., Hasley, A. O., Kraemer, B.M., Latzka, A.W., Marin-Spiotta, E., Meine, C.D., Munoz, S.E., Neeson, Pidgeon, A.M., Rissman, A.R., Rivera.R.J., Syzmanski, L.M., Usinowicz. (2015) The rise of novelty in ecosystems. Ecological Society of America 25(8).

Rao, M., George,L, Rosenstiel, T., Shandas, V. \& Dinno, A. (2014) Assessing the relationship among urban trees, nitrogen dioxide, and respiratory health. Environmental Pollution 194: 96-104.

Rao, S., Kilmont, Z., Smith, S.J., Van Dingenen, R., DenGerneN, F., Bouwman, L. et al. (2017) Future air pollution in the shared socioeconomic pathways. Global Environmental Change 42: 346-358. Retrieved from: https://www.sciencedirect.com/science/article/pii/S0959378016300723

Rosenberger, R. S. \& Dunn, T. (2018) Outdoor recreation metrics: health, activity and value. Oregon State University. Retrieved from https://www.oregon.gov/oprd/PLANS/docs/scorp/2019-2023SCORP/2018HealthBenefitsEstimatesforOregonians.pdf

Shanahan, D.; Bush, R.; Gaston, K.; Lin, B.B.; Dean, J., Barber, E. \& Fuller, R.A. (2016). Health benefits from nature experiences depend on dose. Scientific Reports 6:28551/DOI:10.1038/sreps8551

Shandas, V., Voelkel, J., Willilams, J. \& Hoffman, J. (2019). Integrating satellite and ground measurements for predicting locations of extreme urban heat. Climate 7:5. doi:10.3390/cli7010005 
Sickenger, Ted. (27 April 2020) Oregon's budget in the age of coronavirus: 'bad news on every front'. Retrieved from: https://www.oregonlive.com/coronavirus/2020/04/oregons-budget-in-the-age-of-coronavirus-bad-news-on-everyfront.html

Soll, Jonathan (2008) Invasive weeds in forest lands: English ivy/Hedera helix. The Nature Conservancy for Oregon State University Extension Service EC 1595-E.

Solomonides, K. (May 2018) personal conversation.

Sommers, K.A., Bernhardt, E.S., Grace, J.B. Hassett, B.A., Sudduth, E.B., Wang, S. \& Urban D.L. (2015) Streams in the urban heat island: spatial and temporal and temporal variability in temperature. Freshwater Science 32:1\}

Spies, T., Franklin, J., Thomas, T. (1988) Coarse woody debris in douglas-fir forests of western Oregon and Washington. Ecology: 69/6: 1689-1702. Doi:10,2307/1941147

Sushinsky, JR, Rhodes, JR, Possingham, HP, \& Gill, TK. (2013). How should we grow cities to minimize their biodiversity impacts? Global Change Biology 19(2), 401-410.

TEEB (2010). The economics of ecosystems and biodiversity ecological and economic foundations. Edited by Pushpam Kumar. Earthscan, London and Washington

Templeton, Amelia (2019) Parks Cuts and a Water Taxi: What you should know about Portland's Proposed Budget. Oregon Public Broadcasting.

The Trust for Public Land (n.d.-a) The 150 largest city parks. Retrieved from: https://www.webcitation.org/5gLFlgHS6?url=http://www.tpl.org/content_documents/citypark_facts/ccpe_150_LargestPark s_08.pdf

Travel Portland (30 April 2020) How we're funding. Retrieved from: https://www.travelportland.com/about-us/business-and-financials/

Tualatin Valley Parks and Recreation District (n.d.a) District information. Retrieved from: https://www.ebparks.org/civicax/filebank/blobdload.aspx?blobid=24326

Tualatin Hills Parks and Recreation District (2012) Comprehensive Annual Financial Report. Retreived from: http://gfoa.net/cafr/COA2012/TualatinHillsParkAndRecreationDistrictOR.pdf

Turner-Skoff, J.B., \& Cavender N. (2019). The benefits of trees for livable and sustainable communities. Plants, People, Planet. 2019;00:1-13. https://doi.org/10.1002/ppp3.39

Van der Bosch, M. \& Bird, W. (2018). Oxford textbook of nature and public health: The role of nature in improving the health of a population. Oxford University Press

Van Deren, M., Armistead, C. (2018) The natural value of Forest Park: An ecosystem services valuation of American's premier urban forest.

Van Deren, M. (September 2018). Personal conversation.

VanderHart, D. (20 May 2020) The Coronavirus will blow an enormous hole in Oregon's budget, economists say. Retrieved from: https://www.opb.org/news/article/oregon-budget-coronavirus-covid-19-economic-impact/

Voelkel, J., Hellman, D. E., Sakuma, R., \& Shandas, V. (2018). Assessing vulnerability to urban heat: A study of disproportionate heat exposure and access to refuge by socio-demographic status in Portland, Oregon. International Journal of Environmental Research and Public Health, 15(4), 640

Voz \& Bureau of Planning and Sustainability (2017) On the Frontline of Climate Change. Voz Environment and Justice Framework. https://www.portlandoregon.gov/bps/article/671034 
Walsh, C.J., Roy, A.L., Feminella J.W., Cottingham, P.D., Groffman P.M. \& Morgan R.P. (2005). The urban stream syndrome: current knowledge and the search for a cure. Urbanization and Stream Ecology 24:3.

World Health Organization (2011) Global burden of mental disorders and the need for a comprehensive, coordinated response from health and social sectors at the country level. Report by the Secretariat. World Health Organization. https://apps.who.int/iris/handle/10665/78898

World Health Organization (2012) Association of available parkland, physical activity and overweight in America's largest cities.Public Health Management Practice 18(5): 423-30

World Health Organization (2012) World Health Organization Statistics. https://apps.who.int/iris/bitstream/handle/10665/44844/9789241564441_eng.pdf?sequence=1

Williams, B.K. (2001) Passive and active adaptive management: Approaches and an example. Journal of Environmental Management 92(5):1371-1378.

Zheng, Y. (5 November 2019). Greater Portland voters approve $\$ 475$ million parks and nature bonds measure. Retrieved from: https://www.oregonmetro.gov/news/greater-portland-voters-approve-475-million-metro-parks-and-nature-bond-measure

Zielinski, A. (2019) Here's how Mayor Wheeler wants to spend city dollars this year. Retrieved from: https://www.portlandmercury.com/blogtown/2019/05/01/26413162/heres-how-mayor-wheeler-wants-to-spend-citydollars-this-year

USFS (2018) iTree Eco Model. Retrieved 11/30/2018: https://www.itreetools.org/eco/ 


\title{
APPENDICIES
}

Appendix A

\section{Forest Park \& Natural Area Values - Stakeholder Interview - May 2018}

\author{
Research Partners: \\ - Renee Myers, Executive Director Forest Park Conservancy \\ - Carole Hardy, graduate student Environmental Science and Management, PSU
}

\section{Masters' Thesis/Background:}

Assign value to benefits from urban forests and natural areas. Develop a framework and model to secure funding for Portland's natural areas with Forest Park as a central case study. Values assigned based on stakeholder input, research, market and transferable non-market values. Develop models for sustainable funding to protect the benefits from nature.

Forest Park is owned and managed by the City of Portland. Forest Park Conservancy is a nonprofit organization that partners with the city to conserve Forest Park. They are responsible for building and maintaining trails, recruiting and managing volunteers, "teaching" stewardship of natural areas. They are also responsible for implementing the Greater Forest Park Initiative - a long term plan to restore Forest Park's features and functions which have been degraded from impacts from urban growth and disturbance. This plan is being executed through a consortium of partners (The Forest Park Alliance).

\section{Goal of Business Interviews:}

Understand how different types of Portland area businesses and organizations value natural areas in general, and specifically, how they value Forest Park. 


\section{Questions}

1. In general, do you think that business should support/invest in the natural environment?

2. What kind of investments do you feel business should make?

3. Does your organization support or make investments in natural environment?

4. What are the current programs?

5. Is it important that an investment be tied directly to a company/organization's business model - i.e. if water is needed for manufacturing, investments are made to protect water sources?

6. Is there value in supporting or investing in the natural environment if it benefits your employees? How and why?

7. Is there a value in supporting or investing in natural environment if it benefits the community as a whole? How and why?

8. Do you believe that your organization receives a direct benefit from Forest Park?

- What benefits?

- What value might you assign to those benefits?

- How do you prioritize these benefits?

- How would you prioritize these potential benefits to your organization?

- Employee physical health - clean air/clean water

- Employee mental health - aesthetics/recreation

- Workforce development/retention

- Attracting workforce to Portland

- Attracting workforce to your organization

- Retaining employee

9. Would it be surprising to know that based on very conservative estimates that Forest Park delivers upwards of $\$ 100$ - $\$ 250$ million of value to the city of Portland every year? Does this information change your perspective? If so, what information do you consider the most impactful, surprising?

10. Does it seem reasonable for Portland to invest a minimum of $\$ 1$ million/year to maintain the benefits delivered by Forest Park?

11. Is it concerning to know that if Portland cannot invest adequately in the management of natural areas, that the benefits and value are highly likely to continue degrade from pressures of urban growth and climate change?

12. What ways would you suggest Portland seek to expand/increase funding for Forest Park and natural areas?

13. Is it important to understand what value the citizens of Portland assign to Forest Park and other natural areas? Why or why not?

14. Are there other businesses or organizations in the Portland area that you think we should speak with? Which ones? Do you have contacts that you would introduce to us?

15. Is there a business organization that you are aware of/part of that would be interested in talking to us? 


\section{Value of Forest Park- Employee Survey for Portland Area Businesses Prepared by Carole Hardy, Portland State University, 5/15/2019}

\section{Purpose of the Survey:}

- To find out the extent to which people employed by Portland area businesses value urban forests, specifically Forest Park.

- $\quad$ To find out how employees prioritize the benefits from nature provided by Forest Park.

- To find out the extent to which it matters to employees whether a company they work for supports conservation.

- $\quad$ To find their willingness to pay for improvements to Forest Park.

\section{Introduction:}

Portland State University and the Forest Park Conservancy are seeking the opinion of employees of Portland area businesses to gain a better understanding of the value the citizens of Portland place on urban forests like Forest Park. We appreciate your time in answering this brief 20 question survey. It should take less than 8-10 minutes of your time.

Background: Forest Park is a 5,200-acre urban forest with 80 miles of trails located five minutes from downtown in the west hills of Portland, Oregon. Like many urban forests, it has been exposed to past disturbances such as logging and fires and is now facing current urban pressures including climate change, increased recreation and invasion of nonOnative species.

The City of Portland owns and manage Forest Park and the Forest Park Conservancy is the sole non-profit that works in coordination with Portland Parks and Recreation to protect and restore the park and maintain its extensive trail network.

Through their combined programs they work to:

- Maintain forest function by removing invasive species and replanting trees and other vegetation

- Provide safe access to the Park through maintaining trails and infrastructure, and

- Provide educational opportunities to learn about the cultural and natural history of the park

- $\quad$ Provide opportunities to volunteer to help steward and care for this unique place.

Funding for these programs comes from grants, businesses and individuals and limited funding from the City of Portland's general fund. As with most urban parks, access to Forest Park is free and has no direct revenue. The management and maintenance of Forest Park exists only as a cost line item in the City of 
Portland's municipal budget. As a result, funding to maintain and restore Forest Park can be deprioritized based on other demands.

1. How often do you visit Forest Park? Select 1 of the following:

$\square$ Never

Once a Year

$\square$ Once a Month

Once a Week

Several Times a Week

Every Day

1a.. (If never) Why have you not visited Forest Park?

$\square$ I am not familiar with Forest Park

$\square$ I don't know how to get there

$\square$ It isn't convenient. I tend to visit other more accessible places for an urban forest experience.

\ I visit smaller parks closer to my where I life

$\square$ It's too crowded

$\square$ I have physical limitations that prevent access

I don't frequent urban forests

Other:

2.What activity(s) do you do when in the Park. Mark all that apply.

Walking/hiking

Running/jogging

Biking

Horseback riding

Bird watching

Wildlife viewing

$\square$ Sitting

$\square$ Walking my dog

Pulling ivy or other volunteer restoration work

Other: 
1. Generally, how long do you stay in Forest Park when you visit? Select 1 of the following:

$\square$ Under an hour

$\square$ An hour

$\square$ One to three hours

More than three hours

2. Why do you visit Forest Park? Choose your top 3 reasons. Select 3 of the following:

For exercise

Reduce stress

Improve feelings of well being

For other general health benefits

$\square$ Experience nature

$\square$ Entertain visitors

Spend time with my family

Exercise my dog

$\square$ Bird watch

$\square$ To volunteer for restoration or education projects in Forest Park

\Socialize

$\bigotimes$ For a feeling of community

Other

3. How long have you lived in the Portland area? Select 1 of the following:

$\square$ Under 1 year

$1-3$ years

$\square$ 4-7 years

7-20 years

$\square 20+$ years

Have lived here my whole life

4. Did you move to Portland for your job?

Yes 
5. What were the reasons that you decided to move to Portland? Select 1 best answer for each statement: To take my current job

$\begin{array}{ccccc}\text { Strongly } & \text { Somewhat } & \text { Neither Agree } & \text { Somewhat } & \text { Strongly } \\ \text { Agree } & \text { Agree } & \text { Nor Disagree } & \text { Disagree } & \text { Disagree }\end{array}$

To take a previous job

$\begin{array}{ccccc}\text { Strongly } & \text { Somewhat } & \text { Neither Agree } & \text { Somewhat } & \text { Strongly } \\ \text { Agree } & \text { Agree } & \text { Nor Disagree } & \text { Disagree } & \text { Disagree }\end{array}$

For future job opportunities

$\begin{array}{ccccc}\text { Strongly } & \text { Somewhat } & \text { Neither Agree } & \text { Somewhat } & \text { Strongly } \\ \text { Agree } & \text { Agree } & \text { Nor Disagree } & \text { Disagree } & \text { Disagree }\end{array}$

To have access to parks/natural areas within city

$\begin{array}{ccccc}\text { Strongly } & \text { Somewhat } & \text { Neither Agree } & \text { Somewhat } & \text { Strongly } \\ \text { Agree } & \text { Agree } & \text { Nor Disagree } & \text { Disagree } & \text { Disagree }\end{array}$

I have access to recreation within a day's drive of the city

$\begin{array}{ccccc}\text { Strongly } & \text { Somewhat } & \text { Neither Agree } & \text { Somewhat } & \text { Strongly } \\ \text { Agree } & \text { Agree } & \text { Nor Disagree } & \text { Disagree } & \text { Disagree }\end{array}$


The housing options \& prices were attractive

$\begin{array}{ccc}\text { Strongly } & \text { Somewhat } & \text { Neither Agree } \\ \text { Agree } & \text { Agree } & \text { Nor Disagree }\end{array}$

Somewhat

Strongly

Agre

Agree

Disagree

Disagree

There are good shopping options

$\begin{array}{ccc}\text { Strongly } & \text { Somewhat } & \text { Neither Agree } \\ \text { Agree } & \text { Agree } & \text { Nor Disagree }\end{array}$

Somewhat

Strongly

Disagree

Disagree

There are good food/restaurant options

Strongly

Somewhat

Neither Agree

Nor Disagree

Agree

Somewhat

Strongly

Disagree

Disagree

There is a good selection of entertainment options

Strongly

Agree

Somewhat

Agree

Neither Agree

Nor Disagree
Somewhat

Disagree

Strongly

Disagree

The neighborhoods are livable

Strongly

Agree

Somewhat

Agree

There are good community programs
Strongly

Agree

Somewhat

Agree
Neither Agree

Nor Disagree
Somewhat

Disagree
Strongly

Disagree
To be near family
Somewhat

Disagree
Strongly

Disagree

\section{Disagree}

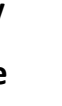


Strongly

Agree
Somewhat

Agree
Neither Agree

Nor Disagree
Somewhat

Disagree
Strongly

Disagree

There are high quality schools

$\begin{array}{ccccc}\text { Strongly } & \text { Somewhat } & \text { Neither Agree } & \text { Somewhat } & \text { Strongly } \\ \text { Agree } & \text { Agree } & \text { Nor Disagree } & \text { Disagree } & \text { Disagree }\end{array}$

Other:

6. What are the reasons that you continue to live in Portland? Select 1 best answer for each statement: I like my current job

Strongly

Agree
Somewhat

Agree
Neither Agree

Nor Disagree
Somewhat

Disagree
Strongly

Disagree

I have access to parks and natural areas within city

$\begin{array}{ccccc}\text { Strongly } & \text { Somewhat } & \text { Neither Agree } & \text { Somewhat } & \text { Strongly } \\ \text { Agree } & \text { Agree } & \text { Nor Disagree } & \text { Disagree } & \text { Disagree }\end{array}$

I have access to recreation within a day's drive of the city

Strongly

Agree

Somewhat

Agree

Neither Agree

Nor Disagree
Somewhat

Disagree
Strongly

Disagree

There are good housing options \& prices

\section{Strongly}

Agree
Somewhat

Agree
Neither Agree

Nor Disagree
Somewhat

Disagree
Strongly

Disagree 
There are good shopping options

$\begin{array}{ccc}\text { Strongly } & \text { Somewhat } & \text { Neither Agree } \\ \text { Agree } & \text { Agree } & \text { Nor Disagree }\end{array}$

Somewhat

Strongly

Disagree

Disagree

There are good food/restaurant options

$\begin{array}{ccc}\text { Strongly } & \text { Somewhat } & \text { Neither Agree } \\ \text { Agree } & \text { Agree } & \text { Nor Disagree }\end{array}$

Somewhat

Strongly

Disagree

Disagree

There is a good selection of entertainment options

$\begin{array}{ccc}\text { Strongly } & \text { Somewhat } & \text { Neither Agree } \\ \text { Agree } & \text { Agree } & \text { Nor Disagree }\end{array}$

Somewhat

Strongly

Disagree

Disagree

The neighborhoods are livable

Strongly

Agree

Somewhat

Agree

Neither Agree

Nor Disagree

Somewhat

Disagree

Strongly

Disagree

There are good community programs

\section{Strongly}

Agree

Somewhat

Agree
Neither Agree

Nor Disagree
Somewhat

Disagree
Strongly

Disagree

To be near family 


\begin{tabular}{|c|c|c|c|c|}
\hline Strongly & Somewhat & Neither Agree & Somewhat & Strongly \\
\hline Agree & Agree & Nor Disagree & Disagree & Disagree \\
\hline$\square$ & $\square$ & $\square$ & $\square$ & $\square$ \\
\hline \multicolumn{5}{|c|}{ There are Quality Schools } \\
\hline Strongly & Somewhat & Neither Agree & Somewhat & Strongly \\
\hline Agree & Agree & Nor Disagree & Disagree & Disagree \\
\hline$\square$ & $\square$ & $\square$ & $\square$ & $\square$ \\
\hline
\end{tabular}

7. How important is it to you to have access to forested areas within the city of Portland? Select 1 option: Extremely important

Very important

Somewhat important

$\square$ Not very important

Not at all important

Does your company provide an employee wellness program? (An employee wellness program might include activities such as company-sponsored exercise, weight-loss competitions, educational seminars, stop-smoking programs, health screenings and other programs that increase health and can reduce health insurance premiums.) Select 1 answer:

$\square$ Yes

$\square$ No

Don't know

8. How important it is to you that the company you work for provides employee wellness programs? Select 1 option: Extremely important

Very important

Somewhat important

Not very important

Not at all important 
9. Does the company you work for provide funding for programs that conserve or restore the natural environment? Select 1 option:

Yes

No

Don't know

10. How important do you think it is for businesses (in general) to provide funding for programs that conserve and restore the environment in the communities where they have offices? Select 1 option:

\section{Extremely important}

Very important

Somewhat important

Not very important

Not at all important

COMMENT (optional):

11. Suppose that you were considered 2 job offers, one from Company $A$ and one from Company $B$ :

- Company A DOES NOT fund environmental programs.

- Company B DOES fund environmental conservation \& restoration programs.

Which company's offer would you accept all other factors but pay being equal?

COMPANY

A

Does not fund environmental program
COMPANY

B

Funds environmental programs

Company A offers 1\% higher pay

Company A offers 3\% higher pay

Company A offers 5\% higher pay

Company A offers 7\% higher pay

12. What types of environmental programs do you feel are appropriate for businesses (in general) to support or fund? Select all that apply.

Sustainable manufacturing/production processes

Increasing access to green spaces throughout the city through purchase of park lands

Restoring forest health through removing invasive species and replanting vegetation/trees

Building and maintaining trails

Protecting wildlife 
Providing education

Funding ecological research

COMMENT (optional):

Demographics - All information is confidential. This information is used only to analyze survey responses.

1. What is the highest education level you have completed? Select 1 of the following options:

$\square$ Some high school

$\square$ High school degree (or equivalent)

$\square$ Bachelor's degree

$\square$ Graduate or professional degree

Associate degree

2. What is the best description of the type of work you do for your company? Select 1 of the following options:

$\square$ Administrative

$\square$ Sales

$\square$ Marketing

Financial

Human Resources

Executive Services

$\square$ Warehouse

$\square$ IT

Security

Delivery

Procurement

3. What is the zip code in which you live?

Zip

4. What is your gender orientation?

$\square$ Male 
$\square$ Female

$\square$ Transgender

$\square$ Other

$\square$ Decline to answer

5. What is your race?

$\square$ White

$\square$ African American or Black

$\square$ American Indian or Alaskan Native

$\square$ Asian

Native Hawaiian or other Pacific islander

$\square$ Hispanic or Latino

From multiple races

Some other race. Please specify:

6. What year were you born?

7. What category comes closest to your total annual household income? $\square$ Less than $\$ 25,000$

$\square \$ 25,000-\$ 34,999$

$\$ 35,000-\$ 49,999$

$\$ 50,000-\$ 74,999$

$\$ 75,000-\$ 99,999$

$\square \$ 100,000-\$ 150,000$

$\square \$ 150,000-\$ 200,000$

Over $\$ 200,000$ 


\section{Portland Business Survey re: Value of Forest Park}

Prepared by Carole Hardy, Portland State University, 6/15/2019

\section{Purpose of the Survey}

- To find out the extent to which business managers and executives in Portland, Oregon value Forest Park.

- To find out which of nature's benefits are most valued by Portland businesses.

- To find out whether Portland businesses support the concept of an environmental partnership between the public and private sectors to financially support the restoration and protection of Forest Park and under what condition businesses would be willing to contribute.

Background: Forest Park is a 5,200-acre urban forest with 80 miles of trails located five minutes from downtown in the west hills of Portland, Oregon. Like many urban forests, it has been exposed to past disturbances such as logging and fires and is now facing current urban pressures including climate change, increased recreation and invasion of nonOnative species.

The City of Portland owns and manage Forest Park and the Forest Park Conservancy is the sole non-profit that works in coordination with Portland Parks and Recreation to protect and restore the park and maintain its extensive trail network.

Through their combined programs they work to:

- Maintain forest function by removing invasive species and replanting trees and other vegetation

- Provide safe access to the Park through maintaining trails and infrastructure, and

- Provide educational opportunities to learn about the cultural and natural history of the park

- $\quad$ Provide opportunities to volunteer to help steward and care for this unique place.

Funding for these programs comes from grants, businesses and individuals and limited funding from the City of Portland's general fund. As with most urban parks, access to Forest Park is free and has no direct revenue. The management and maintenance of Forest Park exists only as a cost line item in the City of Portland's municipal budget. As a result, funding to maintain and restore Forest Park can be deprioritized based on other demands.

\section{About your business}

1. What is your organization's main business? Select all that apply: 
2. Which best describes your business:

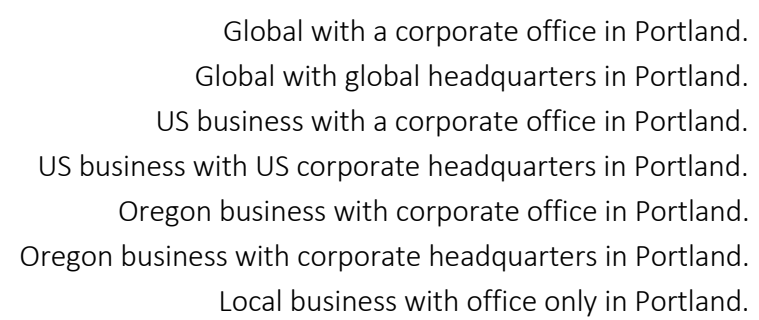

3. Which best describes the size of your business in the Portland Metro area in 2018? Select 1 option:

Micro $\leq 10$ employees

Small 11-50 employees

Medium 50-500 employees

Large $>500$ employees

4. What was the total revenue from your business in 2018? Select 1 option:

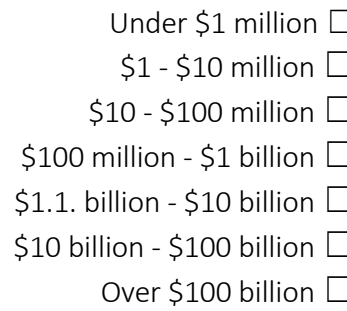

5. Does your organization seek to limit its adverse effects on the natural environment (e.g. through recycling, low emission vehicles, etc.)?
Yes
No

5 A. If yes, what efforts does your organization participate in?

6. Does your organization seek to enhance its beneficial effects on the natural environment through corporate social responsibility programs in the Portland area? 
6 A. If yes, list these programs?

\section{Costs and Benefits of Forest Park}

1. Which of these actions to help protect and restore Forest Park do you consider important for the City of Portland and Forest Park Conservancy to invest in, knowing that each action has an associated cost.

\begin{tabular}{|c|c|c|c|c|c|}
\hline $\begin{array}{c}\text { Actions Required to Protect and Restore } \\
\text { Forest Park }\end{array}$ & $\begin{array}{l}\text { Not at all } \\
\text { important }\end{array}$ & $\begin{array}{l}\text { Somewhat } \\
\text { important }\end{array}$ & $\begin{array}{c}\text { Neither } \\
\text { important } \\
\text { nor } \\
\text { unimportant }\end{array}$ & $\begin{array}{l}\text { Somewhat } \\
\text { important }\end{array}$ & $\begin{array}{c}\text { Very } \\
\text { importan }\end{array}$ \\
\hline Maintenance of trails & $\square$ & $\square$ & $\square$ & $\square$ & $\square$ \\
\hline Removing invasive plants & $\square$ & $\square$ & $\square$ & $\square$ & $\square$ \\
\hline Replanting trees and vegetation & $\square$ & $\square$ & $\square$ & $\square$ & $\square$ \\
\hline & $\square$ & $\square$ & $\square$ & $\square$ & $\square$ \\
\hline $\begin{array}{l}\text { Maintaining culverts for water quality and } \\
\text { quantity }\end{array}$ & $\square$ & $\square$ & $\square$ & $\square$ & $\square$ \\
\hline $\begin{array}{l}\text { Education and outreach to build awareness } \\
\text { and promote community stewardship of } \\
\text { Forest Park }\end{array}$ & $\square$ & $\square$ & $\square$ & $\square$ & $\square$ \\
\hline $\begin{array}{l}\text { Additional Rangers to enforce park rules and } \\
\text { responsible recreation }\end{array}$ & $\square$ & $\square$ & $\square$ & $\square$ & $\square$ \\
\hline $\begin{array}{l}\text { Coordinating opportunities for volunteers to } \\
\text { help steward the Park }\end{array}$ & $\square$ & $\square$ & $\square$ & $\square$ & $\square$ \\
\hline $\begin{array}{l}\text { Improvements to trailheads and increased } \\
\text { public transportation to trailheads }\end{array}$ & $\square$ & $\square$ & $\square$ & $\square$ & $\square$ \\
\hline
\end{tabular}

2. Forest Park can provide a range of benefits to businesses. How relevant/important are these benefits to your business? Select the best option for each benefit:

Benefits from Forest Park

$\begin{array}{ccccc}\text { Not at all } & \text { Not very } & \text { Neither } & \text { Somewhat } & \text { Very } \\ \text { important } & \text { important } & \text { important } & \text { important } & \text { important }\end{array}$


Carbon sequestration \& storage

Improved air quality

Reduced impact from excessive summer heat

Reduced local flood risk

Reduced city noise levels

Improved physical and mental health of employee's residents.

Improved physical and mental health of residents.

Improved appearance/beauty

Attraction of customers / investors
区

$\square$

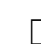<smiles>C1CCCCC1</smiles>

eat

$\square$




\section{Relationship between business and urban natural areas}

4. Does your organization publish a corporate social responsibility plan?

$$
\text { Yes } \square \text { No }
$$

4.A. If yes, is it publicly available)?

5. Does your business integrate non-financial data in your annual financial reports related to corporate social responsibility and sustainability?
Yes
No

5.A. If yes, what types of non-financial data:

\section{Public-private partnerships for Forest Park}

7 The City of Portland has limited municipal budgets to allocate to the maintenance and restoration of Forest Park The Forest Park Conservancy many times partners with local businesses to help fund some of the much-needed work that is required to protect and restore Forest Park. Do you agree with the principle of the private sector contributing to the restoration and protection of Forest Park?
Yes
No

8 Who do you think should contribute to financing the maintenance, restoration and stewardship and education programs in Forest Park? Select all that apply:

\section{City government}

Metro government

Foundations
Businesses (all)

Businesses (those causing greatest impact

on the environment?)

Businesses (those who benefit most

directly from Forest Park?)

Citizens $\square \quad$ Other - please specify:

9 What would be your organization's motivations for contributing to these programs in Forest Park? Select all that apply:

It will increase our profitability through higher sales 
It will improve the health and wellbeing of our employees

It will enhance our reputation as a green and sustainable business in the

Portland area

It supports the aims of our corporate, social responsibility strategy

It will help reduce our exposure to the impacts of climate change

It would help attract and retain employees

It is our moral obligation

It would help encourage other Portland businesses to invest and protect the

livability of Portland

\section{Funding Considerations}

10 If your business were to contribute to the funding of Forest Park would your organization prefer. Select 1 option: An annual contribution toward funding operations?

To select from a list of projects or programs to fund directly?

Other: Please specify:

11 If you voluntarily contributed to the funding of Forest Park, would you wish your organization's contribution to be publicized?

Yes $\square \quad$ No

Conditions of involvement in a public-private partnership How important is it to your

organization to receive reports on the effectiveness of your contributions? 


$\begin{array}{ccccc}\text { Not at all } & \text { Not very } & \text { Neither important nor } & \text { Somewhat } & \text { Very } \\ \text { important } & \text { important } & \text { unimportant } & \text { important } & \text { Important }\end{array}$

12 Which of these would your organization be interested in contributed finance for: Select all that apply:

$$
\begin{aligned}
& \text { Removing invasive species? } \\
& \text { Replanting trees and other vegetation? } \\
& \text { Maintaining trails? } \\
& \text { Improving access to Forest Park? } \\
& \text { Increasing number of rangers patrolling the park } \\
& \text { Improving directional signage }
\end{aligned}
$$

Investing in workforce training for restoration economies for underserved

$$
\text { communities? }
$$

Funding monitoring of ecologic trends to inform management actions?

13 How important to your organization would it be to have other Portland area businesses also participate in the funding of Forest Park? Select 1 option:

$\begin{array}{lcccc}\text { Not at all } & \text { Not very } & \text { Neither important nor } & \text { Somewhat } & \text { Very } \\ \text { important } & \text { important } & \text { unimportant } & \text { important } & \text { Important }\end{array}$

14 Would your organization be interested in challenging other businesses to participate in the funding of Forest Park and potentially other Portland natural areas through a public outreach campaign?

$\begin{array}{cccccc}\text { Not at all } & \text { Not very } & \text { Neither important nor } & \text { Somewhat } & \text { Very } \\ \text { important } & \text { important } & \text { unimportant } & \text { important } & \text { Important }\end{array}$

15 Would your organization be more willing to participate in a funding partnership for Forest Park if you were presented first with?

An environmental case for protection of Forest Park? 
A business case specific to your organization for conservation of Forest Park?

A public health outcome case for conservation and restoration of Forest Park?

Other: Please specify: 
Appendix D:

Link to OWEB Technical Assistance Grant Proposal for Forest Park Research Consortium:

https://middle-earth-economics.business.site/?m=true

Appendix E:

Link to: Hardy et al. (2018) Impact of Ivy on Forest Park: Management Considerations :

https://middle-earth-economics.business.site/?m=true

Appendix F:

Link to: Hardy et al. (2019) Current and Future Ecological Conditions of Forest Park: Management Considerations : https://middle-earth-economics.business.site/?m=true 


\section{Appendix G}

Carole Hardy

Graduate Research Project

Department of Environmental Science \& Management

Portland State University

March 2020

\section{Change in Blood Pressure and Stress in Urban Environments: Research Methodology}

The goal of this research is to understand whether time spent walking in forests decreases blood pressure and stress more than time spent walking in a non-forested urban environment. Blood pressure and stress are two indicators of human health. High blood pressure and stress/depression are two chronic illnesses prevalent among urban dwellers.

\section{Study Design}

FOREST WALK

Study Area: Forest Park

Activity: Participants in the research walk between 30-120 minutes on trails in Forest Park.

Sample: 200 participants.

Data Capture: Data will be captured for analysis in a spread sheet (Table1). Additional variable categories will be added in columns to the left of the Object column. Second BP readings and the average will be captured in additional columns. Field data will be captured on hand-written questionnaires. Participants will be identified by a unique number (Object \#). No personal information will be collected.

Variables:

- Gender: M/F - Equal gender split (40/60 split acceptable).

- $\quad$ Age - 3 categories: 1) 18-34, 2) 35-50, 3) 50-65 - minimum of 50 per age category.

- $\quad$ Time spent: 1) 30 minutes 2) 1 hour 3) 1.5 hours 4) 2 hours

- Income level: 1) Less than \$25K, 2) \$25 - \$50K, 3) \$50K-100K, 4) \$100-\$150K, 5) \$150-\$200K, 6) Over \$200K

- Occupation: 1) Professional, 2) Technician, 3) Service \& Sales, 4) Retired,

- 5) Unemployed, 6) Student

- Education: 1) Some high school, 2) High school degree, 3) Some college, 4) Associates degree, 5) Bachelor's degree, 6) Graduate or professional degree 
- Race: 1) Hispanic/Latino, 2) American Indian, 3) Asian/ Native Islander, 4) Black/African America, 5) White

- Exercise frequency: How often to you exercise (walk/run/dance/cycle) for 30 minutes or more? 1) once a month 2) once a week 3) multiple times a week 4) every day Blood Pressure Readings:

- Pre-readings: Prior to walking, two blood pressure readings will be taken for each participant approximately 5 minutes apart. Prior to the first reading, participants will be asked to sit and answer the questionnaire and indicate their current perceived level of stress. Participants will be seated and quiet during the readings.

- Post-readings: After the walk, two additional blood pressure readings will be taken approximately 5 minutes apart.

- Diastolic and Systolic averages of the two pre and post readings will be used in the analysis.

Stress Levels:

- Pre-reading: Prior to walking the participants will be asked to indicate their current perceived stress level by pointing to a 1-10 scale (similar to a pain scale with faces ranging from happy to highly stressed).

- Post-reading: After walking, the participants will be asked again to indicate their current perceived stress level.

Recruitment: Participants will be recruited through email, social media and signage. An incentive may be offered such as a discount for footwear or outdoor gear.

\section{CONTROL WALK}

Study Area: Downtown Portland

Activity: Participants will walk from $6^{\text {th }}$ and Harrison toward Burnside and back for between $30-120$ minutes.

Sample: 200 participants - equal gender and age split

Variables: Same as Forest Walk

\begin{tabular}{|l|l|l|l|l|l|l|l|l|l|l|l|l|l|}
\hline $\begin{array}{l}\text { Variable: } \\
\text { Age (1- } \\
\text { 3_ }\end{array}$ & $\begin{array}{l}\text { Sex } \\
\text { Seriable: }\end{array}$ & $\begin{array}{l}\text { Var: } \\
\text { Occ } \\
(1-5)\end{array}$ & $\begin{array}{l}\text { Var: } \\
\text { Edu } \\
(1-5)\end{array}$ & Object & $\begin{array}{l}\text { Stress } \\
\text { Pre }\end{array}$ & $\begin{array}{l}\text { Stress } \\
\text { Post }\end{array}$ & $\begin{array}{l}\text { Change } \\
\text { Stress }\end{array}$ & $\begin{array}{l}\text { Diastolic. } \\
\text { BP } \\
\text { Pre }\end{array}$ & $\begin{array}{l}\text { D. } \\
\text { BP } \\
\text { Post }\end{array}$ & $\begin{array}{l}\text { Change } \\
\text { Diastolic } \\
\text { BP }\end{array}$ & $\begin{array}{l}\text { Sys. } \\
\text { BP } \\
\text { Pre }\end{array}$ & $\begin{array}{l}\text { Sys. } \\
\text { BP } \\
\text { Post }\end{array}$ & $\begin{array}{l}\text { Change } \\
\text { Sys BP }\end{array}$ \\
\hline & & & & 1 & & & & & & & & & \\
\hline
\end{tabular}




\begin{tabular}{|l|l|l|l|l|l|l|l|l|l|l|l|l|l|}
\hline & & & & 3 & & & & & & & & & \\
\hline TOTAL & & & & & & & $\begin{array}{l}\text { Mean } \\
+- \text { SD }\end{array}$ & & & $\begin{array}{l}\text { Mean +- } \\
\text { SD }\end{array}$ & & & $\begin{array}{l}\text { Mean } \\
+- \text { SD }\end{array}$ \\
\hline
\end{tabular}

Table 1: Sample spread sheet format. Additional variables will be added. Additional columns will be added to capture multiple BP readings and the average values.

\section{Analysis}

R code will be used to perform the analysis.

Step 1: Determine if there are pre/post differences in the study and control groups and between the study and control groups.

a. Using a paired t-Test, the means of the pre and post readings for 1) stress, 2) systolic BP and 3) diastolic BP for the Forest Walk group will be compared to determine if there is a statistically significant difference between the pre/post readings.

b. The same analysis will be conducted for the Control Walk group.

c. The change in stress, systolic BP and diastolic BP will be compared between the Forest Walk and Control group using a standard t-Test to determine if there are statistically significant differences between these readings for the two groups.

Step 2: Assuming differences are observed, determine what factors may affect observed changes using a 2-way ANOVA.

a. Compare change in stress, systolic, and diastolic BP between males and females by age category.

\begin{tabular}{|l|l|l|}
\hline Age Category & Male & Female \\
\hline 1 & Delta D BP & Delta D BP \\
\hline 2 & Delta D BP & Delta D BP \\
\hline 3 & Delta D BP & Delta D BP \\
\hline
\end{tabular}

b. Repeat for each variable and health indicator (stress, DBP, SBP)

\begin{tabular}{|l|l|l|}
\hline Income Category & Male & Female \\
\hline 1 & Delta D BP & Delta D BP \\
\hline 2 & Delta D BP & Delta D BP \\
\hline
\end{tabular}




\begin{tabular}{|l|l|l|}
\hline 3 & Delta D BP & Delta D BP \\
\hline 4 & Delta D BP & Delta D BP \\
\hline 5 & Delta D BP & Delta D BP \\
\hline
\end{tabular}

